Andrews University

Digital Commons @ Andrews University

\title{
A Twenty-First-Century Approach to Empowering the Youth of the Brooklyn Temple Seventh-day Adventist Church
}

Newton Upanton Cleghorne

Andrews University

Follow this and additional works at: https://digitalcommons.andrews.edu/dmin

Part of the Practical Theology Commons

\section{Recommended Citation}

Cleghorne, Newton Upanton, "A Twenty-First-Century Approach to Empowering the Youth of the Brooklyn Temple Seventh-day Adventist Church" (2003). Professional Dissertations DMin. 505.

https://dx.doi.org/10.32597/dmin/505

https://digitalcommons.andrews.edu/dmin/505

This Project Report is brought to you for free and open access by the Graduate Research at Digital Commons @ Andrews University. It has been accepted for inclusion in Professional Dissertations DMin by an authorized administrator of Digital Commons @ Andrews University. For more information, please contact repository@andrews.edu. 


\section{ABSTRACT \\ A TWENTY-FIRST-CENTURY APPROACH TO EMPOWERING THE YOUTH OF THE BROOKLYN TEMPLE SEVENTH-DAY ADVENTIST CHURCH}

by

Newton Upanton Cleghorne

Faculty Adviser: A. Barry Gane 


\title{
ABSTRACT OF GRADUATE STUDENT RESEARCH
}

\author{
Dissertation
}

Andrews University

Seventh-day Adventist Theological Seminary

Title: A TWENTY-FIRST-CENTURY APPROACH TO EMPOWERING THE YOUTH OF THE BROOKLYN TEMPLE SEVENTH-DAY ADVENTIST CHURCH

Name of researcher: Newton Upanton Cleghorne

Name and degree of faculty adviser: A. Barry Gane, D.Min.

Date completed: March 2003

\section{Problem}

In several churches in the Northeastern Conference and, in particular, the Brooklyn Temple Seventh-day Adventist Church, the adult membership has dominated the positions of leadership. Most of the potential youth leaders have painfully become spectators rather than players and leaders in the church.

The goal of this dissertation, therefore, is to develop and implement a program to empower these youth through training, mentoring, positioning, and liberation.

The Method

Any theology that does not have a biblical foundation is suspect and, therefore, humanistic. A theology of youth ministry was developed within a biblical context. The 
intent of the study was to embrace the biblical underpinnings that would give it legitimacy. There was an historical overview of the inception and development of youth ministries in the Seventh-day Adventist Church and the Brooklyn Temple Seventh-day Adventist Church. The program to empower youth was presented. This consists of a prechurch Leaders-in-Training survey geared to identify responses to the areas of needs for the training seminars, a Post-Leaders-in-Training survey to discover how the effectiveness of the training seminars, and an evaluation of the entire program.

\section{The Results}

The results of the surveys revealed a vast improvement in the lives of the youth with respect to the understanding and detailing of their responsibilities as leaders. The evaluation indicated that there was an overwhelming appreciation for and approval of the program conducted. The participants in the program felt that because of the value and importance of the program, it should be conducted over a longer period in order to get the maximum benefits from it. Between 80 to 100 percent overall improvement was achieved at the end of the presentations, when compared to the beginning of the seminars. The participants believed that the program was worthy of being conducted around the entire conference territory: Hence, there will be an effort developed to take the program to all the churches of the Northeastern Conference.

\section{Conclusions}

The Brooklyn Temple of Seventh-day Adventists has experienced a spiritual renaissance. The youth have been trained and have indicated the confidence they now possess in their theoretical and practical knowledge of the many aspects of their 
leadership preparation.

The church has become a youth-friendly church, creating a positive environment where youth feel like partners in ministry with the adult members. The youth have been placed in numerous offices and have assumed some of the leading ones, which require them becoming members of the church board. The youth have also been given the opportunity to execute their responsibilities in a creative manner. Where the traditional approaches have not been as effective in more contemporary settings; the youth are testing and utilizing innovative approaches to do effective ministry. They are having resounding success.

Truly, the youth of the Brooklyn Temple Seventh-day Adventist church have been empowered through training, mentoring, positioning, and liberation, and are ready to make a difference in the lives of the youth of the church and those in the ambit of their influence. 
Andrews University

Seventh-day Adventist Theological Seminary

\title{
A TWENTY-FIRST-CENTURY APPROACH TO EMPOWERING THE YOUTH OF THE BROOKLYN TEMPLE SEVENTH-DAY ADVENTIST CHURCH
}

\author{
A Dissertation \\ Presented in Partial Fulfillment \\ of the Requirements for the Degree \\ Doctor of Ministry
}

by

Newton Upanton Cleghorne

March 2003 



\title{
A TWENTY-FIRST-CENTURY APPROACH TO EMPOWERING THE YOUTH OF THE BROOKLYN TEMPLE SEVENTH-DAY ADVENTIST CH'URCH
}

\author{
A dissertation \\ presented in partial fulfillment \\ of the requirements for the degree \\ Doctor of Ministry
}

by

Newton Upanton Cleghorne

APPROVAL BY THE COMMITTEE:
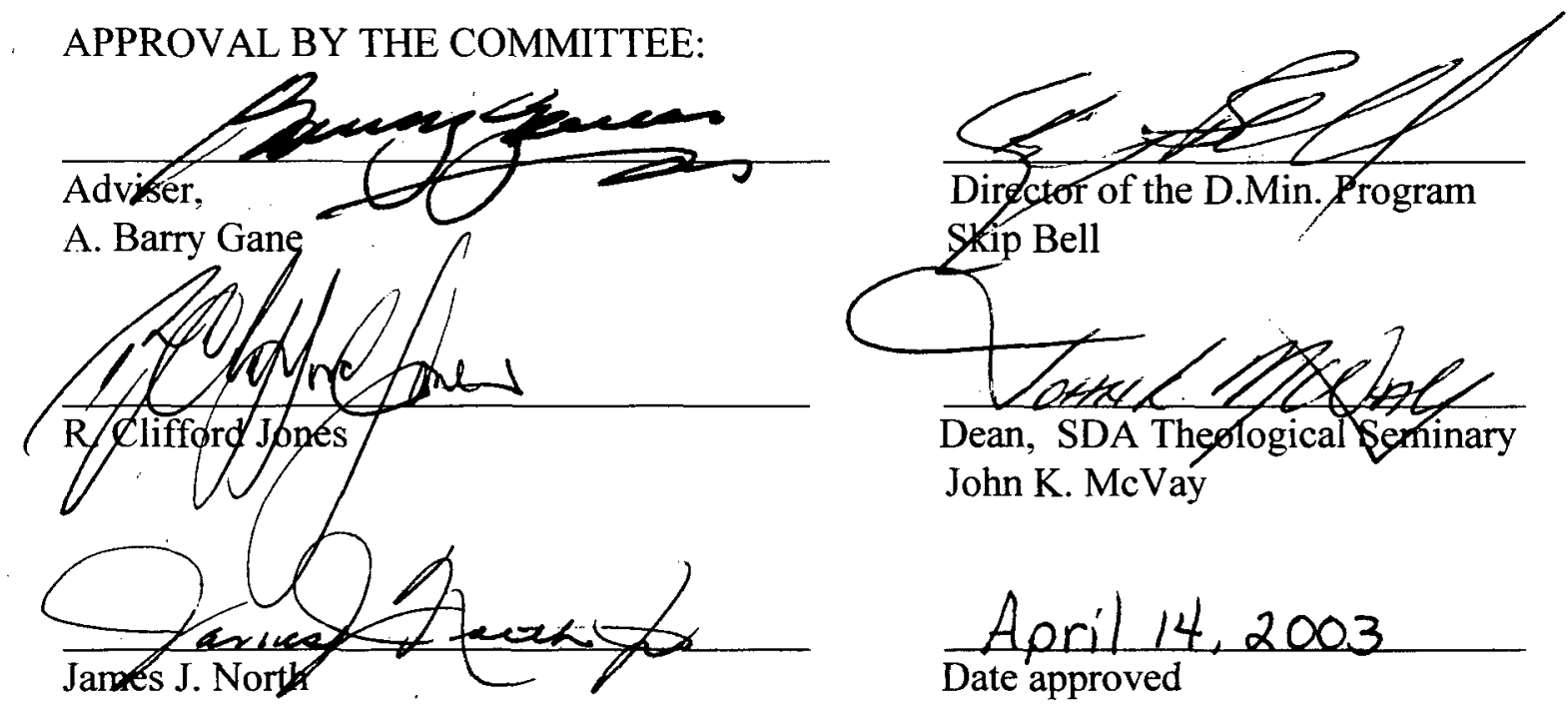


\section{DEDICATION}

This dissertation is dedicated to the great God of the universe, the God of all the youth-past, present, and future who have been empowered through training, mentoring, positioning, and liberation and have dedicated their lives to the fulfillment of the cause for the total participation and involvement of their gifts, talents, and skills in the ministry, .. message, and mission of the church.

It is also dedicated to the committed adult church members who are always willing to see that the youth are mentored and nurtured to take the baton of leadership from the twenty-first century to the second coming of Jesus Christ.

To my beloved wife, Wayne: your constant inspiration, support, and fervent prayers have sustained me during this journey. You are the best. 


\section{TABLE OF CONTENTS}

ACKNOWLEDGMENTS $\ldots \ldots \ldots \ldots \ldots \ldots \ldots \ldots \ldots \ldots \ldots \ldots \ldots \ldots \ldots \ldots \ldots \ldots$

\section{Chapter}

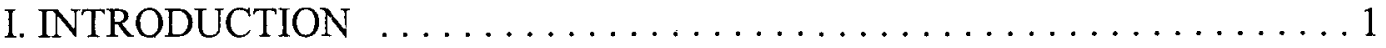

Statement of the Problem $\ldots \ldots \ldots \ldots \ldots \ldots \ldots \ldots \ldots$

Statement of the Task. . . . . . . . . . . . . . . . . . 4

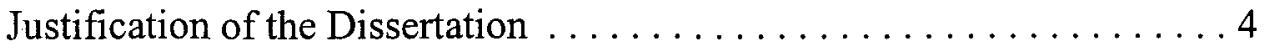

Description of the Dissertation Process $\ldots \ldots \ldots \ldots \ldots \ldots \ldots$

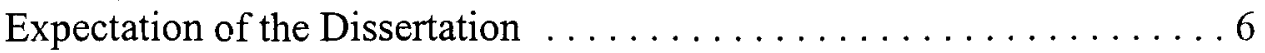

II. A THEOLOGY OF YOUTH MINISTRY $\ldots \ldots \ldots \ldots \ldots \ldots \ldots$

Biblical and Theological Reflection $\ldots \ldots \ldots \ldots \ldots \ldots$

Youth-related Words in the Bible $\ldots \ldots \ldots \ldots \ldots \ldots \ldots$

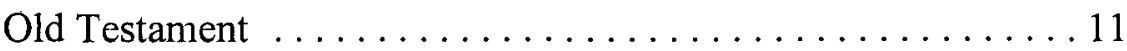

New Testament ........................ 14

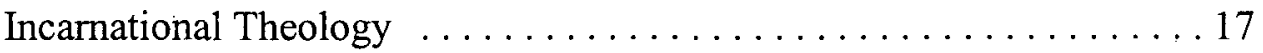

Ellen $G$. White and Ministry to Youth . . . . . . . . . . . 18

Youth Ministry in Contemporary Christian Writing ........... 21

Development a Theology and Philosophy of Youth Ministry . . . . . . 25

Personal Theology and Philosophy of Youth Ministry ...... . . 34

III. THE INCEPTION AND DEVELOPMENT OF YOUTH MINISTRY . . . 38

In the Seventh-day Adventist Church $\ldots \ldots \ldots \ldots \ldots$

The Year $1844 \ldots \ldots \ldots \ldots . \ldots \ldots$. . . . . . . . . . . . . 39 
The Emergence of the Remnant . . . . . . . . . . . 41

The Formal Establishment of the SDA Church . . . . . . 42

Youth Ministry in the SDA Church . . . . . . . . . 43

Youth Ministry Now ..................... 53

The History of Youth Ministry in the Brooklyn Temple

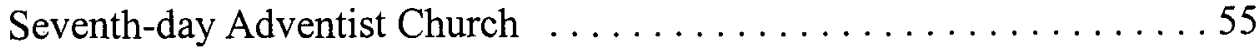

IV. THE PROGRAM TO EMPOWER YOUTH $\ldots \ldots \ldots \ldots \ldots \ldots \ldots$

The Empowerment 64

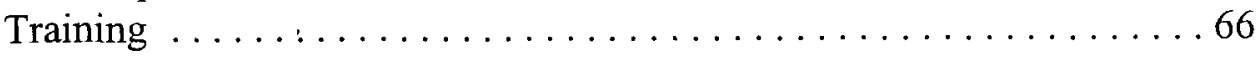

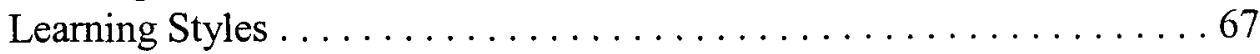

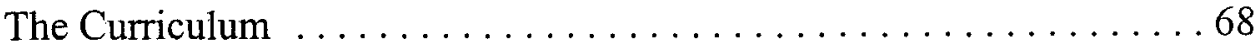

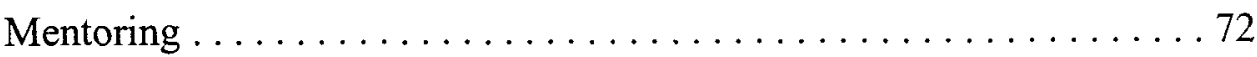

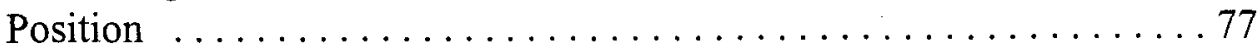

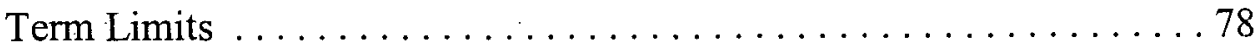

Liberation . . . . . . . . . . . . . . . . . . . 79

V. FIELD TESTING AND ANALYSIS $\ldots \ldots \ldots \ldots \ldots \ldots \ldots$

The Church Leaders-in-Training Pre-course Survey . . . . . . . . . . 85

The Church Leaders-in-Training Post-course Survey . . . . . . . . . . . 92

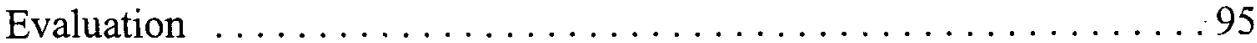

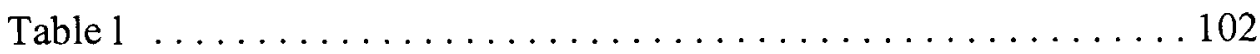

The Testimony of the Pastor, Mentor, Trained Youth . . . . . . . 104

VI. SUMMARY, CONCLUSIONS, AND RECOMMENDATIONS . . . . 106

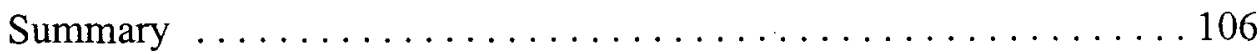

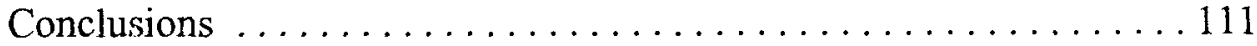

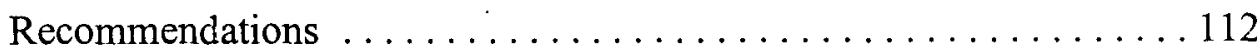

Appendix

A. CHURCH-LEADERS-IN-TRAINING SEMINARS . . . . . . . 118

B. INSTRUMENTS AND EVALUATION . . . . . . . . . . . 202

C. CELEBRATION OF SUCCESS .................. 207

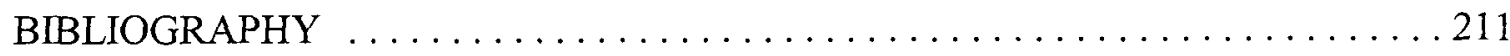

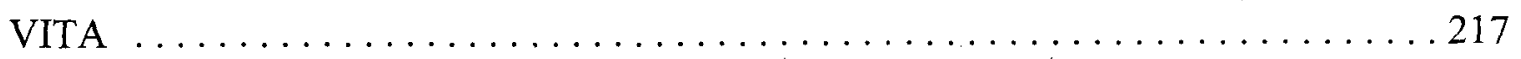




\section{ACKNOWLEDGMENTS}

The Sovereign God of the Universe

My late Parents, Mr \& Mrs. Thomas B. Cleghorne

My beloved wife, Wayne E. Neslin, for twenty-three years of spotless love and devotion in marriage

My Brothers and Sisters \& their spouses, Vermont \& Nancy, Vilma, Balfour \& Patsy, my late sister, Cynthia \& Cordinel (Bill) and their children (my nieces and nephews)

My mother-in-law, (mom) Beryl Rhobe-Ireland, My brothers and sisters-in law \& their children

My mentors, Dr. Ronald Smith, Dr. Bertram Melbourne, Pastor \& Mrs. E. Roy E. Wright, Sr., Pastor Basil A. Reid; Pastor Clinton L. Burrows, Pastor Stennett Brooks

My Teachers and professors past \& present, Dr. Audley Dwyer, Dr. A. Barry Gane (D. Min. Project Adviser), Dr. R. Clifford Jones (second reader), and Dr. James J. North (third reader)

The Duncans Seventh-day Adventist Church, the West Jamaica Conference of Seventh-day Adventists and the Northeastern Conference of Seventh-day Adventists

Harrison Memorial High School, West Indies College (now Northern Caribbean University) and Andrews University

My colleagues in ministry Pastor \& Mrs Trevor Baker, Pastors Farell Jones, Calvin Harrison, Barrington Campbell, Eric Nathan, Ernie Wright, Jr., Pastor' \& Mrs Willie Oliver, Dr. Rollin Shoemaker, Dr. Garnet Morris, Miss Esther Toussaint, Miss Marva Mortley and the Members of the Youth Advisory Council

Pastor Brian L. Carter and the Brooklyn Temple Seventh-day Adventist Church

The Northwestern St. Elizabeth-Southeastern Westmoreland district of churches, The Brownsville, Sharon and City Tabernacle Seventh-day Adventist Churches

The awesome, unpredictable, promising, out-of-the-box, godly and rightly-trained youth "This dissertation is for you. Use it to change the world." 


\section{CHAPTER I}

\section{INTRODUCTION}

The concern that gave rise to the writing of this dissertation has its genesis in the observations I have made when visiting the constituent churches in the Northeastern Conference and a number of churches across the North American Division. The issue is the adult domination of church offices and leadership roles. It was not only obvious, but painfully disturbing.

If we truly believe that the youth must take their rightful place in the church and become effective players and not just spectators, we have an awesome task to ensure that this becomes a reality. In order for this to be realized, each local congregation must take a proactive approach in empowering the youth through the training, mentoring, positioning, and liberation process.

This dissertation seeks to present an effective training program for youth that will guarantee their loyalty, not only to the church's ministry, mission, and message, but their loyalty to Jesus Christ.

Too often, many adult members are needlessly intimidated and even threatened by the energy, talent, innovation, creativity, and out-of-the-box thinking and plans demonstrated by younger church members. Thus, they resist any move by the body to include and involve them in the management, leadership and direction of the church. 
This has caused untold tension, distrust, resentment, and even apostasy from the church. This must cease if we are to preserve the most important segment of our church-our youth.

What adult members must know is that the youth have fertile minds that are ready to explore unchartered waters and new horizons in accomplishing the task of reaching peers, associates, and others with the gospel of Jesus. For us to make an indelible impression on today's youth, it cannot be business as usual. We must be willing to take risks to ensure that our youth have ownership of all that transpires from the local congregation to the General Conference. It is a proven truth that what human beings own, they will support.

Elder Robert Folkenberg, immediate past president of the General Conference of Seventh-day Adventists, challenged the church very early in his administration to allow the youth to have a piece of the pie in the administration of the church. That was a brilliant idea. However, the youth expressed their appreciation for the wisdom and insight, but responded that they do not want just a piece of the pie, they want to help make the pie.

Ellen G. White, called to the prophetic office at the age of seventeen, was on target when she placed a scathing rebuke at the doorsteps of the church:

There has been altogether too little attention paid to our children and youth, and they have failed to develop as they should in the Christian life, because the church members have not looked upon them with tenderness and sympathy, desiring that they might be advanced in the divine life. ${ }^{1}$

'Ellen G. White, Counsels to Parents, Teachers and Students (Hagerstown, MD: Review and Herald Publishing Association, 1913), 41. 
We can require them to be effective and participatory only when we intentionally train them to do the work of the church in a manner that encourages excellence and total success. Indeed, children and youth are our most precious human resource. They will guarantee the longevity and vitality of any church organization so long as the environment is created that will equip and empower them to reach their full potential in service to God and their fellow men.

The Brooklyn Temple Seventh-day Adventist Church was chosen to be the laboratory for such empowerment through training, mentoring, positioning, and liberation of her youth.

\section{Statement of the Problem}

In the Brooklyn Temple Seventh-day Adventist Church a significant number of its membership is between the ages of ten and thirty-five (ages that are accepted as the age of Youth: Junior, 10-15; Senior, 16-22; and Young Adult, 23-35).

Though cognizant of this reality, the church has not engaged and involved them as sufficiently as it should. Thus, the youth have sat on the sidelines, watching the adult members conduct the business of the church without their significant involvement or input. For too long this segment of the membership has experienced spectator status and has not been active participants in the execution of the message, ministry, and mission of the congregation. As a result, there has been a significant exodus from the church because the youth feel that they are not needed, valued or included. If this hemorrhaging does not stop, we will lose the most precious resource that the church has-our youth. 


\section{Statement of the Task}

The task of this dissertation is to develop and execute a program of empowerment that will lead to greater participation, involvement of, and appreciation for the trained youth in the Brooklyn Temple Seventh-day Adventist Church of the Northeastern Conference.

\section{Justification for the Dissertation}

1. The Bible is replete with the priesthood-of-all-believers motif. It is crystallized in 1 Pet 2:9. The Bible informs us of the reality that youth are included in the priesthood of all believers. This inclusion is not based upon age, but upon the fact that they are members of the family of God, endowed with equal rights and privileges.

2. The remnant prophetess, Ellen G. White, makes it abundantly clear that "with such an army of workers as our youth rightly trained [emphasis supplied], might furnish, how soon the message of a crucified, risen and soon coming Savior might be carried to the whole world."

3. There are scores of Seventh-day Adventist scholars and authors who have addressed and endorsed the subject under discussion.

4. There are scores of non-Seventh-day Adventist scholars and authors who have addressed, endorsed, and promoted this concept of empowering the youth.

5. The pioneers of the Seventh-day Adventist Church were mainly youth. Regrettably, the tradition of involving youth in the leadership and management, message, ministry, and mission of the church has not continued in a significant way.

'Ellen G. White, Messages to Young People (Hagerstown, MD: Rèview and Herald Publishing Association, 1958), 196. 
6. Research needs to be done to determine the reason for this present situation. It needs to show how effective the church will be when it exemplifies shared management and leadership with its youth in an atmosphere of participatory democracy.

7. If we neglect to involve our youth in the ownership of the church and what it stands for, we are very likely to lose them.

\section{Description of the Dissertation Process}

1. A significant part of the resources utilized were gleaned from the James White Library, in collaboration with the office of Youth Ministries at the Seventh-day Adventist Theological Seminary and the Center for Youth Evangelism, also located at the Seventh-day Adventist Theological Seminary, Berrien Springs, Michigan. Additional sources emanated from the inter-library network in North America. I also drew from my own experience as a youth, youth pastor, and Conference youth director.

The procedure followed to assemble the relevant data was meaningful. It is reflected in the following seven points:

1. The portions of the Bible that highlight the involvement of youth were studied carefully and used as a springboard for the research.

2. The writings of Ellen G. White, dealing with the need to empower youth, were brought into focus.

3. The contributions made on the subject by Seventh-day Adventist authors and scholars were identified, studied, and utilized in this project.

4. Sources outside the pale of Seventh-day Adventism were sought, studied, and used to buttress and give a broader picture to the subject at hand. 
5. A user-friendly program was developed and executed covering the entire process for empowering the youth in the Brooklyn Temple Seventh-day Adventist Church.

6. The program was field tested, analyzed, and reviewed for its usefulness, effectiveness, and consequent adoption for the wider level of the constituency.

7. The estimated date for completion of this project is March 31, 2003.

\section{Expectation of the Dissertation}

1. This dissertation will provide the Brooklyn Temple Seventh-day Adventist Church with an effective program to empower the youth of its membership into active service through the process of training, mentoring, positioning, and liberation.

2. It will challenge the church at all levels to be cognizant of the need to empower the youth into active participation in its message, mission, ministry, and management.

3. It will excite the youth within the church as they anticipate the prospects of a "new day" in their full participation and involvement within the church.

4. It will be a worthwhile contribution to the literature in the area.

5. It will assist local congregations within the Northeastern Conference to harness the abilities of the youth now, so they will experience the connectedness to and the ownership of their church.

6. It will further equip me to execute my responsibilities to the youth with greater understanding, sensitivity, and professionalism. 
CHAPTER II

\section{A THEOLOGY OF YOUTH MINISTRY}

Any intentional, serious, contemplative, and quality reflection on youth requires that we define who a youth is and then what Youth Ministry is. The Poet Robert Savage in his Pocket Quips describes a youth in a most interesting way:

A youth is a person who is going to carry on what you have started. He will assume control of your cities and nations. He is going to take over your churches, schools and corporations. You may adopt all the policies you please, but how they are carried out depends on him. So it might be well to pay him some attention. ${ }^{1}$

This chapter shows that a biblical and theological reflection becomes the sine qua non for a full understanding of the terms youth and youth ministry.

\section{Biblical and Theological Reflection}

Youth ministry devoid of a biblical and theological undergirding is suspect. For it to be legitimate and credible, it must have deep roots in the Word of God. The demands and expectations of the times require that this concern be given top priority as we seek to develop and conduct our lives and influence others within the context of those biblical and theological pillars. If the church is going to make a difference in the life of its youth, 157.

'Robert C. Savage, Pocket Quips (Wheaton, IL: Tyndale House Publishers, 1984), 
8

there must be a clear understanding of the theology of youth ministry from a biblical perspective and supported by the prophetic counsels of Ellen G. White.

\section{Youth-related Words in the Bible}

In both the Old and New Testaments, the Bible uses several words that are directly related to the youth. Youth have a significant place in Scripture. While it is possible for other biblical concordances or lexicons to give a larger or smaller number of the occurrences of a word, according to Young 's Analytical Concordance to the Bible, ${ }^{l}$ the Hebrew words bachur occurs forty-three times and means choice, young, unmarried men (see Prov 20:29, Eccl 11:9). Bechurim occurs once in Num 11:28 and means choice, young unmarried men. Yeled occurs ten times and means child or "the young of man" (see $1 \mathrm{Kgs} 12: 8$ ). Naarah occurs six times and means a young female (see Ruth 4:12). Elem occurs once in 1 Sam 20:22 and literally means a hidden or growing young person. Tsair occurs ten times and means small (see Gen 19:31, 34). Qatan occurs thirteen times and means little (see Gen 9:24). Qaton occurs seventeen times and means little (see Gen 42:13).

In the New Testament, the Greek word brephos occurs once in Acts 7:19 and means a babe, infant, or child. Elassōn occurs once in Rom 9:12 and means smaller or inferior. Neanias occurs five times and means a young person (see Acts 7:58).

Neaniskos occurs ten times and means a young man in the prime of his life (see Matt 19:20)). Neōteros occurs nine times and means new or young.

The words youth and youthful have both Hebrew and Greek origins. The Hebrew

'Robert Young, Analytical Concordance to the Bible (Grand Rapids, MI: Wm. B. Eerdmans Publishing Company, 1985), s.v. "Youth." 
word bechuroth occurs twice and means youth (see Eccl 11:9). Ben occurs once in Prov 7:7 and means a son of. Choreph occurs once in Job 29:4 and means youth or maturity. Yalduth occurs twice and means youth or childhood (see Ps 110:3). Neuroth occurs once in Jer 32:20 and means youth. Neurim occurs forty-five times and means youth (see Gen 8:21). Naar occurs four times and means a young person (see Judg 8:20). Noar occurs two times and means youth (see Job 36:14). Aumim occurs four times and means youth (see Job 20:11). Tseirah occurs once in Gen 43:33 and means littleness or youth. Schacharuth occurs once in Eccl 11:10 and means dawn or youth. Neotês occurs five times and means youth (see 1 Tim 4:12) and neōteriskos occurs once in $2 \operatorname{Tim} 2: 22$ and means youthful.

The evidence shows, however, that when one narrows down the list of words, two remain prominent that help us understand the Old and New Testament concept of a "Youth": the Hebrew word na 'ar and the Koine Greek word neos.

According to An Expository Dictionary of Biblical Words, na' ar (See Gen 14:24) occurs 235 times and means youth, lad, or young man. ${ }^{1}$ Generally, "na 'ar denotes a young man who is of marriageable age and is still a bachelor." The age of this young person is "usually twenty, since that is when individuals passed from youth to maturity." According to Luis Fernando Ortiz in his doctoral dissertation, "Toward a Theology of Youth Ministry and Its Praxis in the Local Church," Na ar carried important documents, was trained in the art of warfare, and even gave counsel to the king as in the

'An Expository Dictionary of Biblical Words (EDBW) (1985), s.v. "Youth."

${ }^{2}$ Ibid., s.v. "Youth."

${ }^{3}$ The Interpreter's Dictionary of the Bible (1962), s.v. "Youth." 
case of Ahasuerus' attendants who advised him to conduct a search for young virgins (Esth 2:2)." Naar was also "a respected young person capable of performing duties and responsibilities in different capacities."2 Some additional examples of naar are the Levites (1 Chr 16:4; 23:24) and Rehoboam's young advisors (2 Chr 10:8).

Neos (see Acts 23:17-21) and its derivatives appear forty-one times in the New Testament; its adjective form expresses time "belonging to the present moment." ${ }^{3}$ One derivative of neos is neanias meaning "youth or young man, and is used for one who is in the prime vigor of his life and under the age of thirty." Another derivative of neos is neaniskos "which conveys the same meaning as neanias"5 (Matt 19:20,22). The plural of neaniskos, neaniskoi, refers to the younger members of the community (Acts 5:10).

It is clear from the frequency of the use of the Greek and Hebrew words for a young person that the Bible indicates that the youth occupy a significant place in the annals of biblical literature and history. It was a time for assuming positive roles in the religious and political life of the people. The use of these words clearly demonstrates the importance of young people in Bible times. They were never to be looked down upon but were to be cherished as valuable citizens. Both Hebrew and Greek cultures were

${ }^{1}$ Luis Fernando Ortiz, "Toward a Theology of Youth Ministry and Its Praxis in the Local Church" (D.Min. diss., Andrews University, 1977), 8.

${ }^{2} E D B W$, s.v. "Youth."

${ }^{3}$ O. Behm, "neos," Theological Dictionary of the New Testament (1977), 4:896.

${ }^{4}$ Ibid., 897.

${ }^{5}$ The Interpreter's Dictionary of the Bible (1962), s.v. "Youth." 
supportive of young people.

\section{The Old Testament}

From the Old Testament there are many incidents of youth standing up for principle under adverse circumstances. These clearly demonstrate the ability of our youth to be examples for other youth, and adults as well, throughout the ages.

Joseph in Potiphar's house had to take a stand against moral impurity. He refused to defile his body with the wife of Potiphar. He exclaimed with certitude and conviction, "How then can I do this great wickedness and sin against God?" (Gen 39:9).

Moses had to make a decision as to which position was eternally better-becoming a Pharoah in Egypt or being the one to deliver the children of Israel out of bondage. $\mathrm{He}$ made a monumental decision. The book of Hebrews carries that decision: "By faith Moses, when He became of age, refused to be called the son of Pharaoh's daughter, choosing rather to suffer affliction with the people of God than to enjoy the passing pleasures of sin" (Heb 11:24-25). ${ }^{1}$

Gideon was called by God to defend the Israelites against the Midianites. The unusual occurred to Gideon as he proved the Lord in the fleece (Judg 6:36-40) and later in the selection of the army that would go up against Midian and defeat them (Judg 7).

Samuel showed moral strength among the evil sons of Eli. He also demonstrated that age was not a factor in God's call to spiritual service. Hannah gave her son Samuel to the Lord as a token of His favor in opening up her womb, so she could be spared the shame that was brought upon women who did not have children. In 1 Sam 3:8, while still

\footnotetext{
${ }^{1}$ Unless otherwise indicated, all scriptural references will be from the New King James Version.
} 
a "boy," God revealed to Samuel the destruction that would come to Israel. In 1 Sam

3:19-20, Samuel was declared by all Israel to be a prophet.

Ellen White was fascinated by this and commented on this unexpected and unusual prophetic role that came to Samuel at such an early age:

It was not customary for the Levites to enter upon their peculiar services until they were twenty-five years of age, but Samuel had been an exception to this rule. Every year saw more important trusts committed to him; and while he was yet a child, a linen ephod was placed upon him as a token of his consecration to the work of the sanctuary.'

It was Samuel who established the schools of the prophets after his disturbing observation of the conduct of parents in relation to their children:

Fathers and mothers in Israel became indifferent to their obligation to God, indifferent to their obligation to their children. Through unfaithfulness in their home, and idolatrous influences without, many of the Hebrew youth received an education differing widely from that which God had planned for them and learned the ways of the heathen. ${ }^{2}$

It was the prophet Samuel whom the Lord used to select Saul to be the first King of Israel. This indicates the very important role that young people performed, making for new changes in the lives of the people of God.

Solomon, who was the wisest man and king who ever lived, gave the best council to the young: "Keep your Creator in mind, while you are young! In years to come, you will be burdened down with trouble and say, 'I don't enjoy life anymore'." (Eccl 12:1,

'Ellen G. White, Christian Education (Battle Creek, MI: International Tract Society, 1893), 216.

${ }^{2}$ Ellen G. White, Education (Boise, ID: Pacific Press Publishing Association, 1903), 45-46. 
CEV). ${ }^{\prime}$

David, the shepherd boy, was filled with righteous indignation when he realized that Goliath was taunting and disrespecting the armies of the Lord and the Lord Himself. He took up the challenge to fight and kill the Philistine's giant. Amidst all the discouragement from the political establishment, his family, and the enemy itself, he defeated the giant and liberated Israel from Philistine oppression. It was David who succeeded Saul as king of Israel.

Josiah was only eight years old when he was called to be king. He reigned thirtyone years in Jerusalem. He did what was right in the sight of the Lord, and walked in the ways of his father David; he did not turn aside to the right hand or to the left (2 Chr 34:1, 2). This young king ordered a spiritual reform throughout Jerusalem and brought God's people back to a knowledge of the true God.

Daniel and his three friends, Shadrack, Meshack and Abednego, exiled in a foreign land, exemplified what it meant to be steadfast and true to the principles of righteousness. First, they would not compromise their dietary principles (Dan 1:8). Second, they would not bow down to the image of gold that Nebuchadnezzar had set up in the plains of Dura. Despite the threat to be thrown in the burning fiery furnace, they stood their ground. Their miraculous deliverance by the presence of God Himself in the fire caused the idolatrous king to acknowledge the true and living God (Dan 3:25, 28, 29). Their faithfulness earned them promotions to be in charge of the province of Babylon. Daniel would not cease praying to his God three times a day as he opened his window towards Jerusalem. Despite

${ }^{1}$ The Contemporary English Version (CEV) (New York: American Bible Society), 1995. This is an attempt to bring the Scriptures into more modern and current usage. 
the threat to be thrown into the lions' den, he remained faithful. The lions' mouths were locked while he was in the lions' den and he came out unharmed. Again, the true God was recognized by another king, Darius, who established a greater respect for Daniel and his God (Dan 6:20-28). His faithfulness was developed during his youth and continued even to the time of his death.

The prophet Joel prophesied that, in the last days, God would pour out His spirit upon all flesh. He was specific in that he said the sons and daughters shall prophecy. Your young men shall see visions and your old men shall dream dreams (Joel 2:28-31). He would pour out His Spirit also upon the handmaids. Here, again, the youth are included in the outpouring of the Holy Spirit in the last days. This is a leading role that the youth have been given. While dreams are received during the time of slumber, visions can be received at any time and at any place and under any circumstance as God directs. It is therefore God's calculated intention to empower the youth to be at the forefront of a spiritual revolution that will characterize the end of time, ushering in the second Advent of Jesus Christ.

\section{The New Testament}

In the New Testament, Jesus is in the temple at the age of twelve (Luke 2:42) conversing with the great men of erudition and baffling them with His knowledge and wisdom (Luke 2:46, 47). It was said of Jesus, "And the child grew and became strong in spirit, filled with wisdom; and the grace of God was upon Him. And Jesus increased in wisdom and stature, and in favor with God and men" (Luke 2:40, 52). 
Jesus was very tender to children and the young. When the disciples turned the mothers with their infants away, Jesus rebuked them and declared, "Let the little children come to Me, and do not forbid them; for of such is the kingdom of God" (Luke 18:16). It was Jesus who stated emphatically that "whoever causes one of these little ones who believe in Me to sin, it would be better for him if a millstone were hung around his neck and he were drowned in the depth of the sea" (Matt 18:6).

In the book of Acts, Philip the evangelist had four daughters who were prophets. They were young and virgins (Acts 21:9). Just as Samuel was set aside for the temple services, these young women were also set aside for the prophetic role. God is showing here that there is no gender or age bias in His program. He calls and equips those whom He chooses irrespective of prevailing opinions that may lean to the contrary.

Paul was responsible for the grooming of Timothy. He challenged Timothy, "Don't let anyone make fun of you, just because you are young. Set an example for other followers by what you say and do, as well as by your love, faith, and purity (1 Tim 4:12, CEV). Paul knew that Timothy was somewhat shy and reserved in speech. He also knew that he was much younger than the elders in the churches where he pastored and therefore he would feel threatened by their age and experience. Paul wanted to make sure that Timothy was not going to allow any of these circumstances to cause him not to function at optimum, so he sent him this counsel. In a biblical context, this was a youthful age. We learn from the Seventh-day Adventist Bible Commentary on 1 Tim 4: 12 that Timothy was probably not forty years old, and yet would have 
numerous elders under his charge $(5: 1,17,19) \ldots$. Some have concluded that Timothy was timid and reticent by nature, more given to obey than to command, and that Paul's counsel here was intended to correct this supposed defect. Youth is no barrier to a rich spiritual fellowship with God, and old age is not a guarantee of sound thinking or complete dedication. Men, according to Paul, are to be judged by their sanctified abilities and not by arbitrary standards such as age. ${ }^{1}$

The Bible is clear on how God views young people. He considers them equally valuable and worthy as those older than them. He gives them His Holy Spirit and equips them with the spiritual gifts needed to fulfill their individual roles in His service. He calls them to be political leaders, kings, priests, prophets, and advisors, and to lead armies against the enemies of God, spiritual revolutionists determined to remove every vestige of evil present among God's people and to restore righteousness. God has proven that He is not a God who is gender, age, or experience biased. He uses whomever He calls and chooses, whatever the individual circumstances. It is a proven truth: "God's biddings are His enablings. $" 2$

Theology is the study of God, which leads to a knowledge and understanding of God. A. Barry Gane in his book, Building Youth Ministry: A Foundational Guide, deliberately challenges us as we make the initial step to understanding youth ministry: "When we begin to look at youth ministry, the first questions we must ask are: 'what is my theology of youth ministry?' and 'How does my view of God affect how I relate to young

I"I Timothy," The Seventh-day Adventist Bible Commentary, ed. Francis D. Nichol (Hagerstown, MD: Review and Herald Publishing Association, 1980), 7: 305-306.

${ }^{2}$ White, Messages to Young People, 101. 
people?"'

According to Jay Kessler,

Our personal theology affects everything we do in youth work. It will influence the type of message we bring, the response we expect, the progress of the youth to whom we minister, our method of counseling, our attitude towards others and how we measure results. In short, all we do relates to what we actually believe. ${ }^{2}$

\section{Incarnational Theology}

Our theology of youth ministry is found in the life and ministry of Jesus. He is our model for incarnational theology. The Bible provides the basis for incarnational theology and ministry. Phil 2:5-11 tells us unequivocally that Jesus emptied Himself and became a servant in order to reach sinful human beings with His salvation power. It is the surrender of divinity and the taking up of humanity. It is God becoming man so we may become His sons and daughters. In our desire to reach young people, we will have to exhibit the example of Jesus. We must come close to the youth despite the challenge they may pose for themselves and for us, in order that they might be saved. That is the reason for us to state emphatically that any theology of youth ministry that is not built upon a solid biblical foundation will be driven just by sociological, psychological, and political factors that are current at the time. In fact, it will be totally humanistic.

${ }^{1}$ A. Barry Gane, Building Youth Ministry: A Foundational Guide (Riverside, CA: La Sierra University Press, 1997), 50.

${ }^{2}$ Jay Kessler; "Determining Your Theology of Youth Ministry," in Youth Leaders' Source Book, ed. Gary Dausey (Grand Rapids, MI: Zondervan, 1983), 23; quoted in ibid. 
We now look at what Ellen White and other Christian writers say about incarnational theology, followed by my personal theology and philosophy of youth ministry drawn from the plethora of sources.

\section{Ellen G. White and Ministry to Youth}

Among the writers who have significantly contributed to the literature focusing on the theology, training, and preparation of youth for active service is the prophetess Ellen G. White. She was called to the prophetic office in December of 1844 when she was only seventeen years old. She served the Seventh-day Adventist church for seventy years, and was one of the pioneers of this organization. Her contribution then is significant to this project as she repeatedly spoke and wrote about the need for youth to be given their rightful place in the church and the world.

Not only did Ellen White understand the mind of the youth, but she clearly understood the theology of youth ministry. She espoused the incarnational model-one which must be understood for there to be any salvation for our youth. In her book Ministry of Healing she states: "Christ's method alone will give true success in reaching the people. The Savior mingled with men as one who desired their good. He showed His sympathy for them, ministered to their needs, and won their confidence. Then He bade them, 'Follow Me."'’

Herein lies the five secrets of a successful youth ministry. Jesus was deliberate in the steps He took to reach the hearts of those for whom He sacrificed all of heaven. In

${ }^{1}$ Ellen G. White, Ministry of Healing (Boise, ID: Pacific Press Publishing Association, 1942), 143. 
common terms, Jesus socialized, sympathized, served, secured, and saved those He reached out to. If Jesus utilized this approach to reach the hearts of men and women, boys and girls, and youth, it becomes imperative that we follow the footsteps of the Master.

Ellen White was very familiar with incarnational ministry. She asks a most

profound question, then answers with calculated precision:

Why should labor for youth in our borders be regarded as missionary work of the highest kind? It requires the most delicate tact, the most watchful consideration, the most earnest prayer for heavenly wisdom. The youth are the objects of Satan's special attacks; but kindness, courtesy, and sympathy which flows from a heart filled with love for Jesus, will gain their confidence, and save them from many a snare of the enemy. ... There must be more study given to the problem of how to deal with youth, more earnest prayer for the wisdom that is needed in dealing with minds. . . We should seek to enter into the feelings of the youth, sympathizing with them in their joys and sorrows, their conflicts and victories. ... We must meet them where they are if we would keep them. ... Let us remember the claim of God upon us to make the path to heaven bright and attractive.'

Youth ministry built on this model seeks to meet people where they are and offer them pastoral care not only as spiritual guides, but also as counselors and friends, fellow pilgrims on a similar journey.

She continues to emphasize the need to give the youth quality time and attention if we will win them to the Lord and create the positive environment necessary for their spiritual journey:

The youth need more than a casual notice, more than an occasional word of encouragement. They need painstaking, prayerful, careful labor. He only whose heart is filled with love and sympathy will be able to reach

${ }^{1}$ Ellen G. White, Gospel Workers (Mountain View, CA: Pacific Press Publishing Association, 1892), 207-212. 
those youth who are apparently careless and indifferent. ${ }^{1}$

Reaching our youth cannot be done by happenstance or surprise. It must be executed after careful planning because they are precious and deserve the best. The real problem we are facing in doing successful and meaningful youth ministry is identified in the book Counsels to Parents, Teachers and Students:

There has been altogether too little attention paid to our children and youth, and they have failed to develop as they should in the Christian life, because the church members have not looked upon them with tenderness and sympathy, desiring that they might be advanced in the divine life. ${ }^{2}$

With Jesus as our Model, we are called to a ministry that is both personal and relational that will involve empowering and releasing young people to become a part of the ministry to their peers and others. In this there is no place for the power-hungry, because it is a call to selfless service. Jesus exemplifies and embodies this truth, "but whosoever desires to become great among you, let him be your servant. And whoever desires to be first among you, let him be your slave-just as the Son of Man did not come to be served, but to serve, and to give His life a ransom for many" (Matt 20:26-28).

When the church truly understands its priorities and makes the ministry to youth first and foremost on its agenda, it will exemplify this profound statement:

The work that lies next to our church members is to become interested in our youth; for they need kindness, patience, tenderness. ... They ought to be those whose hearts are touched by the pitiable situation in which they are placed, and who realize that Satan is working by every conceivable

\author{
'Ibid., 208. \\ ${ }^{2}$ White, Counsels to Parents, Teachers and Students, 41.
}


device to draw them into his net. ${ }^{1}$

Then the incarnation will mean something to us, because we will finally understand what it cost the Son of God to come to a world that was already four thousand years in sin. He took a risk with the possibility of yielding to sin, so He could save them to the uttermost those who come unto God by Him. This act of God becoming man is recognized as the "mystery of all mysteries."

\section{Youth Ministry in Contemporary Christian Writing}

There are many youth ministry professionals who have made significant contributions to the development of this significant area of ministry. From local churches, conferences, unions, divisions, and small classrooms to sophisticated state-of-the-art seminaries, their influence is felt and their literary offerings respected and appreciated. For them the incarnational approach to youth ministry is the standard by which all youth ministry approaches must be measured, negotiated, and tested.

The question must be posed: To which generation must we direct our energies? Which generation or generations must we focus on that will be the recipients of a youth ministry in this twenty-first century that has a different approach — that scratches where it itches? The answer to these very important questions is what shall be highlighted, plus the continued emphasis on the incarnationl theology defended and shared by these scholars.

Tony Jones of Advent 2000 writes:

${ }^{1}$ Ibid.

${ }^{2}$ Ellen G. White, A Faith to Live By (Boise, ID: Pacific Press Publishing Association, 1989), 48. 
Many call it the most important cultural shift in five hundred years. Some call it the Second Reformation. Most commonly call it postmodernism. While most of our bosses are beholden to the methods of the past, we are immersed in the postmodern world. And God may call upon us, the youth workers, to be the prophets within his church, to wake it from its modernistic slumber. ${ }^{1}$

It is believed by many that postmodernity is a generational issue. However, Brad Cecil believes that "it's not a generational issue exclusive to Gen-X [and] or Millennials. In fact, it's fast becoming the adopted epistemology of all adults. Everyone in ministry-not just youth and young adult pastors will have to wrestle with this phenomenon."

It was Frederick Nietzche (1844-1900) who made his famous declaration, "God is dead" and began a movement that is at the heart of postmodernism-deconstruction. What is deconstruction?

It is a philosophical movement and theory of literary criticism that questions traditional assumptions about certainty, identity, and truth, asserts that words can only refer to other words, and attempts to demonstrate how statements about any text subvert their own meanings. ${ }^{3}$

Deconstruction gained momentum in the first half of the twentieth century as it became clear that science is not capable of answering all questions and the human mind may not be able to solve every problem. All the foundations constructed by foundationalism during the modern period were questioned, and all of the premises that

. ${ }^{1}$ Tony Jones, Postmodern Youth Ministry (Grand Rapids, MI: Zondervan Publishing House, 2001), 10-11.

${ }^{2}$ Brad Cecil, quoted in ibid.

${ }^{3}$ Jones, 20. 
were taken for granted were scrutinized. "The premise of postmodernism is, then, to question all premises. All assumptions are out of the window. For a postmodern philosopher, who is on a quest to show that all is relative and nothing can be taken for granted, skepticism and cynicism rule the day." Should we freeze because of this philosophical scare tactic? Should we become immobile by this new wave of thinking? I believe that this is a brand-new day for youth ministry-a brand-new day to reach the hearts of our young people with the saving knowledge of Jesus Christ.

Dan Kimball's comment is a breath of fresh air on the horizon of youth ministry. It sheds rays of hope upon the challenge that faces us and makes an allusion to Acts 17:

Postmodernity may be the greatest thing that's ever happened to youth ministry. The youth culture landscape is becoming much as it was for Paul in Acts 17, and the potential for evangelism is incredible. We have the holy privilege of reintroducing Jesus and the Christian faith to ears and hearts that have never heard the real thing before. But we have to resist clinging to modern methodologies, despite their past-and current successes. We must completely rethink what it means to engage and dialogue with teens. Ours are extremely exciting, very promising times. ${ }^{2}$

Modernism asserted that absolute truth existed outside ourselves and that it could be discovered by human achievement. Postmodernism claims that absolute truth does not exist, and therefore each person must decide what is truth for himself or herself. As Gary Swanson informs, "What is truth for one person may be directly opposite of truth for another. Postmodernists thrive on the paradoxical."

'Ibid., 22.

${ }^{2}$ Ibid., 43.

${ }^{3}$ Gary B. Swanson, "The Challenge of Postmodernism: Youth Ministry in a World with Zero Gravity," Youth Ministry Accent 3 (2002): 20. 
Since the Enlightenment, Western Christianity's emphasis has featured information and argument. Christianity has also based its evangelistic emphasis on propositional truth. In today's culture, youth are more focused on experience than on information. Sheer logic no.longer has the impact it once did. "In just two generations, the cultural landscape around has been transformed from familiar territory into a foreign land that is resistant to our accustomed ways of sharing the gospel."' In today's culture, we need to let go of our preoccupation with propositions (what we are supposed to think), and replace it with a focus on mission (what we are supposed to be and do).

The target generations in this project are the postmodern generations-Generation $\mathrm{X}$ and the Millennials. These are the generations that challenge us to construct new approaches to doing youth ministry.

The designation "Generation X". is given to those born between 1960 and 1981. Baby Boomers (the generation before Gen-X) have characterized Gen-X by aloneness, brokenness, hopelessness, and distrust of "the system" (the government and the church). ${ }^{2}$ Yet Gen-Xers see themselves as relational, creative, adaptable, community-orientated, ecologically-aware, and global-minded.

Millennials (sometimes referred to as the Net Generation) belong to that group born between 1981 and 2003. While Generation X and Millennials are inexplicably intertwined, for the moment, there is one critical difference between the two:

${ }^{1}$ Ibid., 21.

${ }^{2}$ Rick Hicks and Kathy, Boomers, Xers and Other Strangers (Wheaton, IL: Tyndale House Publishers, 1999), 256-258. 
"Generation X grew up entangled in the revolution of their Boomer parents, while the Millennials are growing up reacting to the revolution."1

Unlike Generation X, this generation is wanted, precious, planned for, and protected. Because society is obsessed with the protectionist mentality, those who work with Millennials have a kind of hands-off approach in their work and relationship with them. This however is the great paradox, because one of Millennials' desires is building relationships. Codrington agrees:

Even more so than Gen-Xers, this generation craves genuine and quality relationships. They want a relationship that will last forever. Attached to this is a deep sense of community, not just in small social groups but connecting with the larger community itself. Millennials actively seek out opportunities that foster togetherness and team spirit. ${ }^{2}$

Let's face it, "our [young people] are neck-deep in postmodern culture every day, and God has called us to be right there with them. And if that's true, and if it is true that culture is changing, then our youth ministries had better change, too."

For us to reach the Postmodern youth, then, we must be willing to build authentic relationships, create a caring community, and engage them in projects of service.

\section{Developing a Theology and Philosophy of Youth Ministry}

From the literature studied it is clear that Incarnational theology and its

${ }^{1}$ Wendy Murray Zoba, Generation 2K: What Parent \& Others Need to Know about the Millennials (Downers Grove, IL: InterVarsity Press, 1999), 41-42.

${ }^{2}$ Graeme Codrington, "12 Sentences That Define Generation Y," August 1999; available from httn://www.vouth.co.za/resource/gemv12.htm: Internet; accessed August 2002.

${ }^{3}$ Jones, 43. 
approach is the answer to the postmodern challenge of reaching and saving our youth. According to the developmental theorist, Erick Erickson, "youth need the ability to be committed to close and lasting relationships and the willingness to sacrifice and compromise as those relationships require." It becomes imperative therefore to come close to our youth by entering into their world with a view of helping them find salvation. When God looked at Adam after creating him, he declared, it was not good for man to be alone (Gen 2:18), so he made him Eve for companionship, fellowship, and relationship. Man is therefore a social creature, needing companionship with others of "his kind" to remain healthy. Man was never made to be hermitic, an introvert, or a recluse. He was made to develop relationships with other human beings. This is the cry and urgent need of the youth in the postmodern world.

In their introduction to Incarnational Ministry Kettler and Speidel inform: "Incarnational ministry is certainly not a new theme for theology or the church. The heart of the faith has always been found in the eternal Word of God, who 'became flesh and dwelt among us, full of grace and truth' (John 1:14)."²

They follow with a most profound, and thought-provoking question, "Is a radical incarnational ministry perhaps a bit threatening because, in the incarnation, God comes too close, becomes too personal?"3 If the answer to this question is yes, then we have

${ }^{1}$ Eric H. Erickson, Childhood and Society (New York: Norton, 1959), 263.

${ }^{2}$ Christian D. Kettler and Todd H. Speidell, Incarnational Ministry: The Presence of Christ in Church, Society and Family (Colorado Springs, CO: Helmers \& Howard, 1990), xiii.

${ }^{3}$ Ibid. 
abdicated our responsibility and have built up impenetrable walls that make us feel safe in our ivory towers of fear and insecurity. Youth ministry requires vulnerability and the taking of risks-risks to save the most precious segment of our society and church-youth. It is impossible to minister to youth if we are not ready to assume these responsibilities. Indeed, incarnational ministry is "the ministry of God in becoming a person in Jesus Christ."

Athanasius declares, "Jesus does not simply sojourn with us, but also heals as a physician who touches our existence with his own being."

Pete Ward presents two kinds of youth ministry: Inside-Out or Nucleus-Fringe and Outside-In or the Incarnational Outreach. "The Inside-Out first works with young people already committed to the church and therefore subsequently attracts people in. It is favored by Christian youth workers because it is extremely successful in socializing young people into the life of the church."

To work incarnationally, Ward continues, is to

step outside predominantly Christian groups. It is to move youth work beyond a church setting into the local community. Outside-in means that youth workers move the Christian group to "be with" those who are outside the life of the church. "Being with" is adopted as a means of sharing the gospel. It is for this reason that many people who have explored this tradition have seen their work as being "incarnational" in nature. This term is used in a technical way as used in missiology to denote the crossing of barriers to share the faith by being with a group of people. Those working

\footnotetext{
'Ibid., xiv.
}

${ }^{2}$ Athanasius, "On the Incarnation of the Word," in Christology of the Later Fathers, ed. Edward R. Hardy (Philadelphia, PA: Fortress, 1949), 97.

${ }^{3}$ Peter Ward, God at the Mall (Peabody, MA: Hendrickson Publishers, 1999), 17. 
Outside-in often speak of meeting people where they are at. The limitations working Outside in is extremely demanding and difficult, while within the church offers a safe and well-defined context of ministry.

Ward continues, "Youthwork which is incarnational will see in the life of Jesus a model for ministry. It is essential, not only to good practice, but also to the proclamation of the gospel, that relationships are at the heart of the work."'

Dean Borgman supports the incarnational approach to youth ministry when he states, "We are called to 'waste time' with young people, 'hanging out' with them."." In order to model incarnational ministry the youthworker must decide to be flexible, creative, and willing to devote quality time. As is observed here:

Unprogrammed social time will form the heart of our ministry, as it seems to have done in the life of Jesus. Young people will learn to become Christians because they are in regular informal contact with Christian people who model faith. The substance of incarnational ministry is the valuing of contact between adults and young people in the everyday and ordinary things of life. Friendship and relationship will not only be the means of ministry, it will be ministry itself. ${ }^{3}$

Doug Stevens was right on target when he wrote, "The church should strive to pattern its endeavor after His original, pioneering, pace-setting ministry, graphically demonstrated in the incarnation. ${ }^{.4}$

Professor A. Barry Gane emphasizes that it was important for Jesus to be alone

${ }^{1}$ Ibid., 37.

${ }^{2}$ Dean Borgman, "Youth Culture, and the Media: Contemporary Youth Ministry," Transformation 11, no. 2 (April/June 1944) : 13.

${ }^{3}$ Ward, 37-38.

${ }^{4}$ Doug Stephens, Called to Care (Grand Rapids, MI: Zondervan Publishing House, 1985), 19. 
with His Father so He could receive the strength necessary to return to His disciples and the teeming multitudes and render needed service to those waiting to be touched by the Master's hand:

Jesus divided his time between the mountain and the multitude. They witnessed his praying, the source of guidance and strength, and his healing, teaching and preaching, his action in the midst of humanity. These things left an indelible impression on the minds of his followers and became a model for their ministry as they were commissioned to tell the world of the reconciliation that Christ had achieved.'

Jesus "brought God within the reach of humanity and made Him understandable. Jesus was God's clearest and most unambiguous statement about himself."2

The youthworker must know that to be of significant blessing to those who lead, there must be a close connection with the Source of all power.

Gane continues to widen the scope for the understanding of the concept of incarnational theology when he states, "The incarnate Jesus Christ is God's clearest and most unambiguous statement about Himself (Heb 1:1-3). In His person, Jesus spelled out God's plan of recovery. ${ }^{3}$

God's plan of recovery must also become our plan to rescue and save our youth. That is the reason for all youth ministry to be built on this model of God becoming manthe experience of the kenosis.

'A. Barry Gane, "Youth Leadership Development in the Local Church" (D.Min. dissertation, Fuller Theological Seminary, 1993), 31.

${ }^{2}$ Ibid.

${ }^{3} \mathrm{Gane}$, Building Youth Ministry, 51. 
Gane puts it into perspective:

Youth ministry built on this model seeks to meet young people where they are, and to offer them pastoral care not only as spiritual guides, but also as counselors and friends, fellow pilgrims on a similar spiritual journey. With Jesus as our model we are called to ministry, a personal and relational ministry, that will involve a good deal of one-to-one time. ${ }^{1}$

There may be some who would make light of the continuous emphasis on building relationships with young people. However it is significant to observe that

all youthwork is based upon relationships with young people. Christian youthwork is no different except that we see relationships not just as an end in themselves but as the means by which young people may experience the presence of Christ. "Being with" young people and getting involved in their lives expresses this incarnational truth. ${ }^{2}$

Ward continues, I believe, with an even greater definition because he nails down the concept of incarnation in the following:

We are the means by which Jesus becomes incarnated among a group of young people. To be incarnational as a youthworker is therefore to live out a spirituality that is deeply rooted in the life of Christ. We are imitators of Christ attempting, by the things we do and say, to offer young people an insight into the heart God has for them. ${ }^{3}$

In order to have a deeper understand of incarnational ministry, one must be aware that the accessibility of the youthworker is critical to its success. As Lawrence Richards points out, "It is imperative to become accessible and understanding to youth; a youth

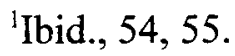

${ }^{2}$ Ward, 103.

${ }^{3}$ Ibid., 105. 
leader must 'become one of them'." A deliberate identification with youth leads to increased ministry.

Even the transmission of a grace orientation requires that we do it in an atmosphere of interpersonal relationships:

The Valuegenesis study reveals that we most effectively transmit a grace orientation to our youth by providing a climate of warmth and acceptance in our local congregations and by the presence of caring teaching in our school system.

We best learn and accept grace through warm, supportive interpersonal relationships with graceful people. ${ }^{2}$

Doug Fields joins the cadre of youth ministry professionals and states

unequivocally the need for relational ministry towards young people and people in general and speaks of how it is practiced at Saddleback church where he is the Youth Pastor:

We value relationships in our youth ministry at Saddleback Church. We want students to have a vital relationship with God through Jesus Christ. We want leaders to have solid relationships with one another, with students, and with students' parents. We want students to have accountable relationships with other students and with their own parents; and we want the church body to have a good relationship with the youth ministry. Relationships are the backbone of all our values. ${ }^{3}$

Steve Gerali, commenting in Starting Right, reveals our awesome responsibility as youth workers to model and reflect the love of Jesus in our lives:

${ }^{1}$ Lawrence O. Richards, Youth Ministry: Its Renewal in the Local Church (Grand Rapids, MI: Zondervan Publishing House, 1979), 25.

${ }^{2}$ Roger Dudley with V. Bailey Gillespie, Valuegenesis: Faith in the Balance (Riverside, CA: La Sierra Press, 1992), 273. See also Roger L. Dudley, Why Teenagers Leave the Church (Hagerstown, MD: Review and Herald Publishing Association, 2000).

${ }^{3}$ Doug Fields, Purpose-Driven Youth Ministry (Grand Rapids, MI: Zondervan Publishing.House, 1998), 235. 
Jesus became like us and dwelt among us for the expressed purpose of allowing us to see his glory. The incarnational ministry that Christ entrusts to the church is for the same purpose. Youth workers are allowed to cross the boundaries of the adolescent community when they become like kids and dwell among them so that the reflection of Christ's glory may be seen through the youth worker. Incarnational ministry means that we are entrusted to be the reflection, representation, and tangible expression of Jesus to kids. ${ }^{1}$

The church is under an irresistible mandate to create a youth-friendly environment in which the young are constantly being nurtured in trusting and meaningful relationships.

Chap Clarke in concluding his study on the missional approach to youth ministry undergirds the concept of incarnational ministry:

God's call is for the entire church community to create a relational environment where people, young and old alike, can experience a deep, rich, family-like environment where discipleship, equipping, nurture, training in spiritual disciplines, and mentoring all occur. This is what all people, and especially young people, need from the church. ${ }^{2}$

Tom Beaudoin points out that the need for relationship among young people is clearly evident in the popular culture. "Our most fundamental question is, "Will you be there for me?",3 This is the key question to address to anyone in youth ministry. It is what young people are looking for, first and foremost.

Swanson again asserts:

Jesus scandalized His community by forming trustworthy relationships

${ }^{1}$ Steve Gerali, quoted in Starting Right (Grand Rapids, MI: Zondervan Publishing House, 1993), 295.

${ }^{2}$ Chap Clarke, quoted in Four Views of Youth Ministry and the Church (Grand Rapids, MI: Zondervan Publishing House, 2001), 92.

${ }^{3}$ Tom Beadoin, Virtual Faith: The Irreverent Spiritual Quest of Generation X(San Fransisco, CA: Jossey-Bass Publishers, 1998), 169. 
with extortioners, prostitutes and outlaws. Surely youth ministry must become more open to forming such relationships-even with sexually active, rowdy, irreverent, tattooed, body-pierced youth.

Once these relationships are formed, young people will be open to the sharing of our personal experience in Jesus. ${ }^{1}$

Postmodernists are more interested in doing things as a team. They want to belong before they are expected to behave and believe-the three B's that are most significant to them. Postmodernists develop a faith in Jesus not because they are convinced through rational argument, but primarily because they experienced God in a warm, caring community. "Faith is highly social."2

Benson and Senter present a tri-partite approach to reaching adolescents with the claims of Jesus. They inform us that adults must be relaxed and natural in working with adolescents. They confess and we confess the difficulty that this may sometimes pose. However, the more comfortable we are in the presence of youth, the greater will be our influence upon their lives and their world.

They further suggest that if we will minister to the young effectively we must understand that:

1. Youth ministry begins when adults find a comfortable method of entering a student's world. 2. Youth ministry happens as long as adults are able to use their student contacts to draw students into a maturing relationship with God through Jesus Christ and 3.Youth ministry ceases when either the adult-student relationship is broken or the outcome of that

'Swanson, 21.

${ }^{2}$ Stanley J. Grentz, A Primer on Postmodernism (Grand Rapids, MI: Eerdmans, 1996), 168. 
relationship ceases to move the student toward spiritual maturity.'

In this process we can predict how ministry to youth might take shape as we process the dynamics of interpersonal relationships.

Postmodernists do not want to be spectators; they want to participate. Young people "do not want to be entertained, but they will not allow themselves to be bored.... What they're looking for is not something to entertain them but something to engage them." 2 Any activity that will encourage young people into the role of participants will appeal to them and exert a greater impact on them. They see service to one another and others as a way of becoming cross bearers and not mere cross wearers. This strikes at the heart of enhancing relationships and building community.

\section{Personal Theology and Philosophy of Youth Ministry}

After reviewing the plethora of biblical, Spirit of Prophecy, and contemporary sources that highlight the study of the theology and approach to youth ministry, I now focus on my personal theology and philosophy of youth ministry.

The incarnate Christ tells us that there is hope. Our model for youth ministry is found in the life and ministry of Jesus-the Incarnational model. Youth ministry developed from this concept seeks to meet young people where they are and build trusting relationships that will empower them to become a part of all the ministries in the church.

\footnotetext{
'Warren S. Benson and Mark H. Senter III, eds., The Complete Book of Youth Ministry (Chicago, IL: Moody Press, 1987), 26-28.

${ }^{2}$ Tim Celek and Dieter Zander, Inside the Soul of a New Generation (Grand Rapids, MI: Zondervan, 1996), 66, 67.
} 
Youth ministry is a call to service, not status. This theology of Youth Ministry hinges upon unconditional love that binds the church together and acts as a magnet drawing others to Jesus. The theology of youth ministry seeks to bring people to Jesus. In Matt 18:5, 14, Jesus made it abundantly clear: "Whosoever welcomes a little child like this in my name welcomes me.... Your Father in heaven is not willing that any of these should be lost.". It means that we should deliberately place ourselves in the midst of the youth subculture so, like Jesus, who entered our world which was already four thousand years in sin, we can do that for our youth with a view to introduce them to the Savior.

I concur with Barry Gane when he argues that "youth ministry includes an intentional focusing on God's saving acts in history in such a way as to meet the needs of young people at their stage of development and draws them into a saving relationship with God through Jesus Christ."”

A philosophy of youth ministry hinges upon a clear understanding of the theology of Youth ministry. Therefore, I agree that youth ministry is building relationships with young people in order to lead them to a lasting relationship with and a commitment to God.

I concur with Duffy Robbins that “youth ministries isn't a matter of budgeting, publicizing and organizing. It is a matter of loving teenagers [and all youth], spending time with them, and helping them hear and understand the gospel of Christ.".2

'Gane, Building Youth Ministry, 50.

${ }^{2}$ Duffy Robbins, Youth Ministry: Nuts and Bolts (Grand Rapids, MI: Zondervan Publishing House, 1990), 15. 
At the heart of youth ministry is the building of relationships. These relationships, if properly established, should bring out the best in our young people. We cannot be aloof and fearful of young people if we are going to effect needed change in their lives. We must practice nearness and intimacy, for it is extremely difficult and nigh impossible to care for someone from a distance with the hope of achieving significant success. Distance can produces apathy, but proximity produces fellowship.

Therefore, it is not in programs and entertainment that youth ministry comes alive. It is in the building of relationships, following the incarnational model, theology, and approach; that becomes the recipe for success.

Youth ministry is not an after-thought. It is a part of God's plan to finish His work. Moses, under inspiration, was right on target in Deut 6:6-9 (CEV). Here, he profoundly prescribes the antidote for the preservation of our children with which I concur:

Keep these words that I am commanding you today in your heart. Recite them to your children and talk about them when you lie down and when you rise. Bind them as a sign on your hand, fix as an emblem on your forehead, and write them on the posts of your house and on your gates.

Every resource from the home, school, church, and nation must be identified and utilized to maximize the energies of our youth. It must not be spasmodic, but intentional in order to make them an integral part of everything we do. Youth ministry, then, is at the heart of the survival of the generations-past, present, and future. Youth ministry, also, is not an option; it is an imperative that must be heeded in order to satisfy the longings of the hearts of young people in every strata of society. 
The Bible, in both Old and New Testaments, clearly indicates that its concept of responsible youthfulness is positive and enlightening. Biblical examples of successful youth in secular, political, and religious life are a breath of fresh air for those who believe in their full empowerment through training, mentoring, positioning, and liberation.

It is true that the only way to influence young people in a positive way is to build trusting and lasting relationships, then release them into active participation in the mission, message, and ministry of the church. This is the incarnational approach that has been tested and proven to be indispensable in our approach to experiencing successful youth ministry.

Chapter 3 focuses on the history and development of youth ministry in the Seventh-day Adventist Church and the Brookiyn Temple Seventh-day Adventist Church. 
CHAPTER III

\section{THE INCEPTION AND DEVELOPMENT OF YOUTH MINISTRY}

For any organization to have continuous significance, its history must be preserved. It is beneficial and instructive for those who follow in successive generations to have an understanding of how that organization was established.

This chapter will focus on the historical genesis and development of youth ministries in the Seventh-day Adventist Church and the Brooklyn Temple of Seventh-day Adventists.

\section{In the Seventh-day Adventist Church}

The Seventh-day Adventist Church was born out of the Great Disappointment of October 22, 1844. At the heart of this historical event was a Deist-turned-Adventist preacher, named William Miller.'

From personal and diligent study of the Bible aided by the Cruden's Concordance, Miller believed that Dan 8:14 meant that Jesus was coming to the earth to cleanse it by fire on the antitypical day of atonement on October 22, 1844. After making

${ }^{1}$ C. Mervin Maxwell, Tell It to the World (Boise, ID: Pacific Press Publishing Association, 1977), 9. According to Deism, God created the world and set it in operation under unalterable laws of cause and effect. In harmony with these laws, men ought to live clean, kindly and honest lives; but to believe in prayer, a Savior, or life after death was regarded as childish superstition. Miracles, forgiveness and resurrection would require God to act contrary His own natural laws, and this was unthinkable. God had wound up the world like a watch and left it to run on its own. 
several suggestions, the exact date was arrived at by one of the Advent preachers, Samuel S. Snow, a friend and colleague of Miller. He carefully explained the twenty-three hundred days (years) prophecy of Dan 8:14 by using a-day-for-a-year principle cited in Num 14:34 and Ezek 4:6. Thousands believed and were converted to this doctrine during the early thirties to the early forties.

\section{The Year 1844}

On October 22, 1844, the Millerites (followers of Miller), after having sold out or given away their possessions, waited for the coming of Jesus. It did not happen. After twelve midnight, the Millerite Adventists experienced the Great Disappointment. Rev 10:8-10 (NKJV) had already predicted the sweetness of the message in the mouths of the advent believers and the bitterness of their disappointment:

Then the voice which I heard from heaven spoke to me again and said, "Go, take the little book which is open in the hand of the angel who stands on the sea and on the earth." So I went to the angel and said to him, "Give me the little book." And he said to me, "Take and eat; and it will make your stomach bitter, but it will be as sweet as honey in your mouth." Then I took the little book out of the angel's hand and ate it, and it was as sweet as honey in my mouth. But when I had eaten it, my stomach became bitter.

The challenge that the disappointed and embarrassed Millerite Adventists faced was deeply rooted in three questions: How did this happen? Where had they gone wrong? Where would they go from here? One group renounced everything they believed and decided to go back into the world. The second group decided to set some other dates and became extremely fanatical. The third group decided that they would go back to the Bible and study it more carefully to discover where they went wrong. This group was 
called the "little flock." James White, Ellen Harmon (now seventeen), John Nevins Andrews, Joseph Bates, the sea captain, and Hiram Edson were some of those who comprised the core of the post-disappointment Millerite Adventists. These individuals would be at the nucleus of the formation of what would become the Seventh-day Adventist Church.

Up until 1852 there were three other fairly coherent Adventist groups in existence:

The first, claiming to have maintained the original advent faith, was centered around Boston and looked to Himes, Bliss and Hale for leadership. The second Adventist group, which developed in the Hartford, Connecticut-New York City area, coalesced around Joseph Turner and his Second Advent Watchman. They believed that the millennium was in the past. The third group was centered largely around Rochester, New York. Its members rallied behind Joseph Marsh's Advent Harbinger and Bible Advocate but were violently opposed to any formal organization. ${ }^{1}$

How did Miller make such a mistake as to think that Christ was coming on

October 22,1844 ? The answer is simply that

he did not adequately examine two of his basic premises. He assumed that so long a time prophecy as the 2300 days must lead to the end of the world, and He assumed that the sanctuary to be cleansed could not be the one in heaven, for he could not see how the sanctuary there could be defiled and need cleansing. In assuming this he was supported by thousands of others, friend and foe alike, many of whom were trained biblical scholars. Miller did not so much "make" these .mistakes as "accept them. ${ }^{2}$

The morning after the Great Disappointment, Hiram Edson, nicknamed Adventism's "grainfield Cleopas,"3 and his friend, O. R. L. Croiser, were walking

'R. W. Schwarz, Light Bearers to the Remnant (Boise, ID: Pacific Press Publishing Association, 1979), 57.

${ }^{2}$ Joe Englkemier, ed., Breakthrough with God's Church: Moving Out (Mountain View, CA: Pacific Press Publishing Association, 1890), 22.

${ }^{3}$ Maxwell, 50. 
through a cornfield on their way to visit some of the disappointed Millerite Adventists. What Edson saw became a watershed and a theological revelation that changed the course of their lives and their understanding of the sanctuary doctrine. Hiram Edson had organized a prayer group after the disappointment to pray and ask God for direction as to where to go from that point. They had met in a barn and pleaded with God to give them direction. This was an answer to their prayer. Edson saw that the heavens were opened and Jesus came out of the Holy Place into the Holy of Holies in the heavenly sanctuary. He and, later on, the rest of the "little flock" understood that it was not the earthly sanctuary that Jesus was coming to cleanse by fire, but He was entering and beginning the second phase of His work as our Great High Priest in the Heavenly Sanctuary. He was removing the sins that had accumulated since Adam up to that time. It is the judgment described by Seventh-day Adventists as the investigative judgment, also known now as the Pre-Advent or Pre-first-resurrection judgement.

\section{The Emergence of the Remnant}

The task of the "little flock" now was to develop a series of doctrines that would be a part of its fundamental beliefs. There was also the need to become formally organized in order to more effectively administer the fledgling group. In 1844 , several significant events occurred. Notably is the beginning of the preaching of the three angels' messages of Rev 14:6-12. This became a part of the core of their preaching and teaching, along with the doctrine of the sanctuary. The doctrine of the seventh-day Sabbath also became a part of the fundamental beliefs of this group. 
The emergence of a prophet among this group was pivotal to its development, progress, and success in every aspect of life. In December of 1844 Ellen Harmon, at the age of seventeen, received her first vision. She saw the difficult path that the Advent people must tred. If they kept their eyes on Jesus, they would be assured of eternal life. Every challenge that this group faced was met and satisfied by appropriate and timely visions that Ellen Harmon, who became Ellen White in 1846, received.

It is significant to note that many of the leaders who became the pioneers in the Seventh-day Adventist church were young people:

James White was twenty-one when he started to proclaim the second Advent message. In one evangelistic Series he conducted, over one thousand souls were baptized. Ellen Harmon was only seventeen, when she received the prophetic gift. John Loughborough was seventeen when he began to preach in 1849 . He gave seventy-five years of his life to the Advent Movement. John Nevins Andrews was only twenty when he first wrote and preached for the Advent cause. He was the denomination's first foreign missionary. Uriah Smith was only twenty when he initially joined the struggling Advent band in Rochester, New York. He became the editor of the church paper, the Review and Herald for many years. ${ }^{1}$

\section{The Formal Establishment of the Seventh-day Adventist Church}

In October 1860, this group voted a name for its organization. They named it Seventh-day Adventist, which means that they keep the seventh day (Saturday) of the week as the Sabbath of the Lord and they look with great anticipation for the second coming of Jesus Christ. Three years later, 1863, they had their first General Conference session, when the church was officially organized and John Byington became its first

'Nathaniel Krum, The MV Story (Washington, DC: Review and Herald Publishing Association, 1963), 7-8. 
president. It is noteworthy that James White, the husband of the prophetess, was asked to serve in that capacity as its first president. He refused, however, citing that since he was the one behind advocating the organization of the church, that it would represent a conflict of interest. However, he later accepted that position and became its president for three terms.

After James White wrote the first Sabbath school lessons for the youth, in the Youth's Instructor, in 1852, a move to ensure that the youth of the church were cared for in an organized manner began to surface. In her book, The Great Advent Movement, Cooper cites:

Stress began to be laid upon various kinds of missionary work within our churches. Societies were formed, and the earnestness and alertness of the young people who frequently took leading parts in them, aroused a consciousness that this was the very thing that would tie our youth to the church. Such efforts, it was foreseen, would also develop leadership qualities in the oncoming generation. ${ }^{1}$

\section{Youth Ministry in the Seventh-day Adventist Church}

In 1879 , a very significant event occurred that would shape, from henceforth, ministry to young people in the Seventh-day Adventist Church. Two young men, Harry Fenner, age seventeen, and Luther Warren, age fourteen, were walking down the old country road of Hazelton, Michigan. They were impressed that youth should be more involved in the sharing of the gospel, so they decided to pray about the matter. After scaling the rail fences along the road, they found a secluded spot underneath some trees

'Emma Howell Cooper, The Great Advent Movement (Washington, DC: Review and Herald Publishing Association, 1968), 90. 
where they knelt down and prayed that God would open up a way to begin a ministry to youth. They brought the matter to the church board, and the board voted to begin the first Young People's Society at the Hazelton (now Juddville Center) Seventh-day Adventist Church, Michigan.

There were only nine charter members-all boys-at the first meeting. There they voted a president and a secretary-treasurer, reported the missionary work for the previous week, drew up and signed a temperance pledge, and took up an offering to purchase literature for missionary distribution and for other expenses.

After a few weeks, the girls became a part of the Young People's Society, thus making it all-inclusive. Twelve years later, in 1891, Meade MacGuire formed a similar group in his church at Antigo, Wisconsin. When he made the proposal to the church, it was met with grave opposition. However, the elder of the church placed his hand on his shoulder and said, "My boy, you go right ahead. You may have the church for your meeting, and I will stand by you."1

In 1892, Ellen White wrote her first testimony in favor of mobilizing the denomination's "army of youth" into active service. Writing from Melbourne, Australia, December 19, 1892, she said:

We have an army of youth today who can do much if they are properly directed and encouraged. ... Let all be so trained that they may rightly represent the truth, giving the reason of the hope that is within them, and honoring God in any branch of the work where they are qualified to labor. ${ }^{2}$

After Ellen White's counsels were taken seriously, the first Young People's

'Krum, 12.

${ }^{2}$ General Conference Bulletin, January 29, 30, 1893, 24. 
Society outside of North America was formed, at the Adelaide Seventh-day Adventist Church in Adelaide, Australia, by the President of the Australasian Conference, Elder A. G. Daniells.

In 1893 the Young People's Society of Christian Service was organized in Lincoln, Nebraska, to secure the increased spirituality of the young people, their enlistment in all missionary activity through existing channels of work, and their elevation to a higher plane of living and thinking.

In 1894, Sunshine Bands ${ }^{1}$ were organized by Luther Warren in South Dakota. A Sunshine Band Convention was held in Bridgewater, South Dakota. In 1896 a small paper named Sunshine was published at Omaha in the interest of this activity.

In Mount Vernon, Ohio, April 1899, the Ohio Conference was the first conference to officially form a general organization for Adventist youth. The meeting was convened, and, at the camp meeting held in August of that year, a state-wide organization known as Christian Volunteers was voted. It was assimilated by the Missionary Volunteer Department upon its organization in 1907.

In 1901, the youth of Sigourney, Iowa, were organized. Several of the groups later went overseas as missionaries, one to Portugal and two to China. That same year a youth society was organized in Des Moines, and shortly thereafter the work expanded in Iowa until there were fourteen societies with 186 young members.

'Sunshine Bands were small groups formed that were designed to help young people share their faith. By sharing their faith they brought sunshine of Jesus into the lives of thase they contacted. 
In 1901 the General Conference began taking steps towards forming an official young people's organization, approving the youth society concept and recommending that a committee be set up to form a plan of organization. The Sabbath School Department, directed by Mrs. Flora Plummer, was asked to care for the youth work at the General Conference level. Mrs. Plummer carried that responsibility until 1907.

At the General Conference Council at Gland, Switzerland, in the spring of 1907, the Youth Department of Missionary Volunteers (MV) was voted. Elder Milton E. Kern became the first world Youth Director. Matilda Erickson was office secretary. In the summer of that year about 200 representative workers gathered at Mount Vernon, Ohio, for a youth convention to select a name for the department and to draw up other recommendations. The Morning Watch Calendar and the Missionary Volunteer (MV) Reading Course were adopted, and the group voted to observe MV Day in each church once a year. The name selected for the department was finally agreed upon as Seventhday Adventist Young People's Department of Missionary Volunteers. Through the years it became known as the MV Department, and the local church youth organization was called the MV Society. Public youth meetings were designated as MV meetings.

At the Mount Vernon Convention a concern for younger members among Adventist youth was expressed and the first official action concerning the work for junior youth was voted. "In California, C. Lester Bond, F. G. Ashbaugh, Julia Leland (Nelson), J. T. Porter, L. A. Skinner and Guy Mann pioneered the Junior Missionary Volunteer (JMV)-now Adventist Junior youth (AJY) approach. J. Nixon of Iowa, Gordon Smith of 
Michigan, Roy Mackenzie and Grover Fattic fostered the youth camp idea."1

By 1911 caring adults organized clubs for boys. Milton P. Robison, then formal director (in charge of teacher training) of Union College, Lincoln, Nebraska, followed the new trend with a group he called Boys' Pais. In Takoma Park, Maryland, the Tacoma Indians Pathfinder Club participated regularly in outdoor activities.

In 1919 A. W. Spalding, probably the foremost proponent of the new approach to junior-youth work, started a Mission Scouts organization at Madison, Tennessee, for his own boys and their friends. He stressed working with the hands and outdoor living: handicrafts, woodcraft, trailing, and camping. "The Mission Scouts developed a law, pledge and aim, which formed the basis of the Pledge and Law eventually adopted by the church for Junior Missionary Volunteers."” Delegates to the Fall Council of 1920 voted to add a secretary (Director) to the General Conference Youth Department, and elected Harriet Holt as an associate MV Secretary to promote the JMV Society. A year later guidelines were outlined for this program and worldwide promotion began.

As youth engaged in JMV Society activities, "sorne leaders felt the need to develop strong Christian characters and prepare for effective witnessing so they would know how to do missionary work." ${ }^{3}$ Class requirements included Bible and nature study, homemaking skills, outdoor activities, first aid, personal and home health, physical fitness, community service, and other avenues for witnessing. These were developed

'Alfredo Garcia-Marenko, ed, Youth Ministry Handbook (Silver Spring, MD: General Conference of Seventh-day Adventists, 2002), 21.

${ }^{2}$ Ibid., 22.

${ }^{3}$ Ibid., 23. 
after careful study of the programs offered by other similar organizations and the present needs of the youth of the church.

During the General Conference session in San Francisco in the spring of 1922 the work of the JMV classes was enhanced by the addition of the concept of Progressive Classwork. In 1926, at Townline Lake, Michigan, Grover Fattic directed the first official MV camp conducted by a conference.

At the 1927 General Conference Autumn Council held in Chattanooga, Tennessee, the Progressive Classwork was enlarged to include three classes: Friend, Companion, and Comrade. Two classes were designed for junior youth and one class for senior youth and young adults. Subsequently, in 1928, C. Lester Bond joined the General Conference MV Department. Two major programs evolved that year-MV Honors and the leadership training course initiated to train Master Comrades (later called Master Guides). This was to prepare senior youth and adults who desired to prepare for Junior leadership. The first Master Comrades were invested in 1931. The MV/JMV classwork (later called AY/AJY) is designed to help the youth in the harmonious fourpartite development of the mental, physical, spiritual, and social capabilities.

The first MV youth congress was held in 1928 at Chemnitz, Germany, in the Central European Division with Steen Rasmussen as youth leader. Youth from the Northern European Division also attended with their Division youth director, Len Minchin, an Australian. The first North American Division youth congress drew thousands of youth. It was held in San Fransico in 1947 with E. W. Dunbar as world youth director. In 1969, the first world youth congress was held in Zurich, Switzerland. 
Theodore Lucas was the then world youth director.

The Character Classics reading plan (later known as the Encounter Series) was adopted in 1946. This plan was to introduce young people to a systematic method of reading and studying the Bible. The ultimate goal was to empower the youth to share their faith with others.

The first conference-sponsored Pathfinder club was organized by John Hancock in the Southeastern California Conference at Riverside, California, in 1946. From 19471950 the Pathfinder program continued to develop in the Pacific Union Conference under the direction of J. R. Nelson, union youth director. Finally, the General Conference adopted the Pathfinder Club organization in 1950. This segment of youth ministry was to serve as a laboratory for boys and girls ten to fifteen years old. It was designed to expose them to the study of nature, outdoor activity, the Bible, and Christian citizenship.

The student missionary program began in 1959 when a student volunteer, sponsored by the Columbia Union College MV Society, left for Mexico to spend a summer there. A few years later the General Conference Youth Department and Secretariat assumed responsibility for maintaining the growing program and voted operational policies to guide its worldwide development. During the ensuing years thousands of student missionaries have served throughout the world. Today, Adventist colleges in many parts of the world divisions send scores around the world to serve in this youth outreach ministry.

In 1972, the name was changed from the Missionary Volunteer Department (MV) to the Youth Department of Missionary Volunteers. Conference MV Secretaries were 
given the title of Youth Directors. However, due to the association of the name Missionary Volunteers (MV) with militant and subversive groups in some parts of the world, the name was changed to Adventist Youth Department (AY) in 1978. The meetings in the local churches are now called Adventist Youth Society (AYS) meetings.

The question then is, What is an AY Society? The Adventist Youth Society is a department of the Seventh-day Adventist Church through which the church works for and through its youth. It is the action and fellowship organization for senior youth and young adults in the local church. Under the leadership of an elected Youth Leader, young people are to work together in the development of a strong youth ministry, which includes the spiritual, mental, physical and social development for each individual.

In the book Gospel Workers, Mrs. White asserts:

In order that the work may go forward in all its branches, God calls for youthful vigor, zeal, and courage. He has chosen the youth to aid in the advancement of His cause. To plan with clear mind and execute with courageous hand, demands fresh, uncrippled energies. Young men and women are invited to give God the strength of their youth, that through the exercise of their powers, through keen thought and vigorous action, they may bring glory to Him and salvation to their fellow-men.'

While there is to be an active AYS in every church, it is important that the youth program not be isolated from the rest of the church. In addition to their participation in the youth organization, the young people should be integrated into responsible leadership and involvement in the entire church program. There should be youthful representations in all offices, committees, and areas of leadership in each church.

The objectives of the AY Society is far removed from entertainment. It is threefold: "To train the youth to work for other youth, to recruit the youth to help their

\footnotetext{
${ }^{1}$ White, Gospel Workers, 67.
} 
church and 'those who profess to be Sabbath keepers' and to work for 'those who are not of our faith'." In summary, "To save from sin and to guide into service."”

Malcolm J. Allen, an Australian and former world Pathfinder leader, concurs with the broad objectives of youth ministry in the Seventh-day Adventist Church:

Adventist youth ministry is not an entertainment program, or a babysitting organization, or another community service club. Adventist youth ministry is God-ordained to save His youth. It is the vehicle to take our young people safely from this earth to heaven so that they will not get lost along the way. All activities and programs must stimulate and capture the youth's attention. Their enjoyment and participation must deepen their relationship with God and focus attention on Adventism's direction and goal. Youth ministry in its totality is designed by God for one purpose only-to save our youth. The programs and activities we offer must sharpen their interest and focus so they will not get bored along the way or be enticed to succumb to the temptations and pleasures of the world. ... True Adventist youth ministry will not lose sight of its goal. Yes, it will provide young people with fun and enjoyment, activity and involvement, but its primary focus will be spirituality and service so that youth will maintain their commitment and interest. The Adventist philosophy of youth ministry must center on the salvation of our youth. It is our goal and our challenge. ${ }^{3}$

In order to effectively realize these objectives there is an AYS Committee that meets, ideally, at least once every month for planning and evaluation. It also meets once every week for prayer preceding each meeting and for a general overview of the meeting about to be conducted. An additional support group that sees to the overall training and empowering of youth is the AY Ministries Committee, which is the umbrella organization in the local church responsible for the general planning of the youth ministry

'Garcia-Marenko, 30.

${ }^{2}$ Tbid., 29.

${ }^{3}$ Malcolm J. Allen; Divine Guidance or Worldly Pressure? (Silver Spring, MD: General Conference of Seventh-day Adventists, 1995), 11. 
program. The AYS leader is the chairperson of this committee. This committee handles every aspect of the life of the youth. Its composition therefore encompasses every department that affects the life of the young people. It identifies and constantly assesses the needs of the youth in the local church. It recommends strategies, programs, and support mechanisms to meet the discovered needs. It coordinates all youth activities in the local church, in conjunction with the Church Board, and supports and promotes local Conference youth activities. It evaluates youth activities and sees that they are meeting the needs they are designed to cater for and recommends appropriate changes where necessary.

The Youth Ministries Department has streamlined itself into tiers of youth ministries. It has done so in order to plan and reach all the youth in their age experience and maturity. Adventurers are those six through nine years old. Pathfinders and Adventist Junior Youth are ten to fifteen years old, the Senior Youth are sixteen to twenty-two, and the Young Adults are twenty-three to thirty-five. Each division of youth ministry is governed by a set of affirmations. These include a pledge, law, motto, aim, and song. In 1953, the MV Legion of Honor was developed during the General Conference Annual Council. It came as a result of much prayer on the part of the MV Advisory Committee. They framed a code to which Adventist youth might voluntarily subscribe, and thus pledge to answer Christ's call and honor Him in the lofty standards of this covenant. It was inaugurated at a time when Adventist youth leaders sensed anew the value of this statement from the pen of Ellen G. White:

Say firmly: "I will not spend precious moments in reading that which 
will be of no profit to me, and which only unfits me to be of service to others. I will devote my time and my thoughts to acquiring a fitness for God's service. I will close my eyes to frivolous and sinful things. My ears are the Lord's and I will not listen to the subtle reasoning of the enemy. My voice shall not in any way be subject to a will that is not under the influence of the Spirit of God. My body is the temple of the Holy Spirit, and every power of my being shall be consecrated to worthy pursuits."

The MV Legion of Honor was developed from the statement written by Ellen G.

White. It reads:

I volunteer now to join the MV Legion of Honor and by the grace and power of God I will: Honor Christ in that which I choose to Behold. Honor Christ in that which I choose to Listen. Honor Christ in the choice of Places to which I Go. Honor Christ in the choice of Associates. Honor Christ in that which I choose to Speak. Honor Christ in the care I give my Body Temple. $^{2}$

This has made a lasting impact on the lives of the youth of the Seventh-day Adventist Church as they have sought to exemplify the tenets of this most profound item of the overall affirmation of the Youth Department.

\section{Youth Ministry Now}

Youth ministry has grown significantly over the years. It has now included in its array of ministries a Bible Bowl involving ages 10-35 where the teams representing the local churches vie for the championship in quick and accurate responses to questions posed from certain books of the Bible. There are at least three models of Bible Bowl: The Black Adventist Youth Directors' Association (BAYDA), the Michigan conference model and the Rocky Mountain conference model. Campus Ministry, both Christian and secular, deals with the establishment of ministries to students on college and university campuses.

${ }^{1}$ White, Messages to Young People, 270.

${ }^{2}$ Krum, The MV Story, 64. 
National Service Organization is responsible for the spiritual care and nurture of our youth in the armed forces and provides council to those who desire to be enlisted. There are Adventist Youth Federation Rallies, Youth Congresses, Youth Olympics, and Pathfinder Camporees, just to name a few. These events are conducted at the local church, Conference, Union, Division and General Conference levels. The Center for Youth Evangelism at Andrews University with its Giraffe University specializes in the training of local youth leaders. Generation X Ministry caters to empowering young adults. The Adventist Association of Camping Professionals (AACP) provides mentoring and professional expertise to those in the camping ministry of the Seventh-day Adventist Church. It also interfaces with other camping organizations to bring to the table the work of the camping ministry of the Seventh-day Adventist church. The Adventist Association of Youth Ministry Professionals was organized to give youth ministry tools to those who are full- and part-time youth ministry professionals and to introduce them to all the agencies, non-Seventh-day Adventist and Seventh-day Adventist, that provide ministry to young people. The department of Youth Ministry at the Andrews University Campus in Berrien Springs, Michigan, was established to prepare those who desire to make youth ministry their life work. It was also to bring a general awareness to the academic and church community of the need to bring into prominence the importance of young people and the potential for their contribution to the success of all segments of society. These are some of the significant strides the Seventh-day Adventist Church has made within the last twenty years to ensure that all our youth are prepared to take their place in the church, home, school, and society. 
From a small group of nine boys in Hazelton, Michigan, this Adventist "army of youth" has grown to nearly 70 percent of the total membership of the Seventh-day Adventist Church. The Seventh-day Adventist Church operates the largest Protestant educational system in the world. Its membership has now reached nearly thirteen million individuals. Its aggressive evangelistic program is largely contributory to this phenomenal growth.

With this formidable approach for youth ministry that has been developed by the Seventh-day Adventist Church, no wonder Ellen G. White had to pen this profound reminder, "We have nothing to fear for the future except as we shall forget the way the Lord has led us and His teachings in our past history."

\section{The History of Youth Ministry in the Brooklyn Temple Seventh-day Adventist Church}

The vision of Brother and Sister Sidney Armstrong to give Bible studies in a home in Brownsville, Brooklyn, New York, was the early beginnings of what was to become the Brooklyn Temple of Seventh-day Adventists. As the Bible Study group grew, they had to move from the house to a store front on Dean Street. In the year 1934 this group was organized as the Gates Avenue Mission at 506 Gates Avenue. Elder Armstrong assumed the leadership responsibilities and carried the full expenses of the church during this period.

In 1941, Gates Avenue Mission moved to 565 State Avenue in Brownsville and became the Brownsville Mission. Two years later, in 1943, this group of believers had

'Ellen G. White, Life Sketches (Mountain View, CA: Pacific Press Publishing Associating, 1915), 196. 
their dream fulfilled. They were finally organized as a church with all rights and privileges at their disposal. The presiding conference official at this event was Elder C. M. Bunker, President of the Greater New York Conference of Seventh-day Adventists.

The joy of the congregation was dulled on Sabbath morning, February 26, 1944, when Elder Armstrong suffered a heart attack on his way to church. He fell on the sidewalk, just ninety feet from the church building. When the medical team arrived he was pronounced dead. The death of Elder Armstrong caused the Greater New York Conference to assign Elder James J. North as the pastor of the congregation in March of 1944.

During Elder North's tenure, March 1944 to October 24, 1959, the church moved to a number of locations until it purchased the current facility which was a former Jewish synagogue located at 3 Lewis Avenue. It was bought for $\$ 83,000$. The congregation began to worship in the building by the end of February 1959. It was during this period, and just prior to Elder North's departure, that the name was changed from the Brownsville Seventh-day Adventist Church to the Brooklyn Seventh-day Adventist Temple.

Since 1959 the church has experienced a steady growth in its membership under the leadership of several pastors: Theodore X. Perry, George Timpson, Harold Baptiste, the late Milton Thomas, the late Sebert Anderson, Gilbert J. Foster, Roy Ashmeade, Craig Dossman, Desmond Francis, Philip Wesley, and, currently Brian L. Carter, who assumed pastoral responsibilities in March of 1999.

The current membership is 436 with an active attendance of almost three hundred. Many churches have been planted by this church: Brooklyn Faith (Brooklyn), Bethany 
(Westbury, Long Island), Brownsville (Brooklyn), New Hempstead (Now Pilgrim Tabernacle, Hempstead, Long Island), Ebenezer (English, Freeport, Long Island), Bethesda (Amityville, Long Island), Corona (Corona, Queens) and most recently the North Brooklyn Seventh-day Adventist Church (Brooklyn). . The church also operates a Pre-K to $8^{\text {th }}$ grade elementary school established in 1965.

The youth of the Brooklyn Temple of Seventh-day Adventists have been actively engaged in multi-faceted ministries since its inception. Before 1978, Missionary Volunteer Society Meetings (MV) were held on Sabbath afternoons. These meetings were sometimes conducted after the regular Bible class. The earliest recollection is that James Brooks was the MV leader. He gave sterling leadership and served for a very long time in this position. He conducted programs mirrored after television shows. There were many discussions on youth issues. The Morning Watch feature was extremely important to the youth of Brooklyn Temple. They enjoyed memorizing all seven texts for the week and staged a competition-like feature to determine who could recite all these texts without a mistake. They sang lustily from the well-known MV song book, The Captain Calls.

According to Dr. James J. North, Jr., "It was from many songs in this song book that a number of us understood the mission of the church and what God wanted us to do as young people." Jack Johnson was a gospel singer and used to conduct the song service. He knew how to get the congregation of youth to participate in singing. Choruses were not the only songs sung, but they also sung hymns from the Church Hymnal. Brooklyn Temple youths were known for their "good music." Musical talent was

'Dr. James North, Andrews University, Berrien Springs, Michigan, interview by author, 9 August 2002. 
plentiful. From violinists to key board players, all provided the landscape for the development of musical greats. Dr. James J. North, Jr., professor at Andrews University's Theological Seminary, is an accomplished musician from that era.

Some of the adults who left indelible positive impressions on the minds of the youth are Walter Blair, James Brooks, Elder Armstrong, and Sister Marie Armstrong, affectionately called Mother Armstrong. She was well loved, especially by the young people.

The outreach activities were many: Tract Distribution, Witnessing in Prospect Park, the Botanical Gardens, and the Zoo. There were also nature walks and time for reflections on the history of the Seventh-day Adventist Church.

The late Willard Smith, a foster son of the Norths, became the AY Leader for many years and took the society to an all-time level of success in all aspects of the development of youth-spiritual, mental, physical, and social. He was an invested Senior Youth Specialist. At the time of the writing of this chapter, the current AY Leader was Charmaine Lauriston who is preparing to be invested as a Senior Youth Specialist.

Pathfinder Ministry has been a hallmark of youth ministry in this church. Several Master Guides have been invested and many have become leaders in the Pathfinder Federation of the Northeastern Conference of Seventh-day Adventists. Wilbur Watson was long-time Chaplain of the Pathfinder Federation. Paul Fyffe is the current Drilling and Marching Instructor of the Pathfinder Federation and Esther Brooks is the Secretary of the Brooklyn-Staten Island Pathfinder Area Federation and the current Pathfinder Director of the Brooklyn Temple Hornets Pathfinder Club. Scores of Pathfinders have 
been invested over the years, and Brooklyn Temple remains a bastion for leadership in the Pathfinder ministry.

Adventurer ministry is also very strong in Brooklyn Temple. The children, ages six through nine, find much nurture and ministry by the staff of the Adventurer Club. Its current Director is Jeanell A. McFarlane. Parents are excited to know that their children are being led to understand their God, their world, their family, and themselves, using creative and innovative approaches.

Despite all the positive things happening in youth ministry in Brooklyn Temple, there needs to be more involvement of the young in the decision-making processes and at the leadership levels of the church. Many young people are still sitting on the fringes as spectators. This must not continue or else we stand a chance of losing them. This is the reason for the development, study, and test of the program at the Brooklyn Temple of Seventh-day Adventists: to empower the youth through training, mentoring, positioning, and liberation. This will give the youth the needed edge to effectively and knowledgeably assist in the leadership and management of the church in all phases.

The history of youth ministry in the Seventh-day Adventist Church and the Brooklyn Temple Seventh-day Adventist Church is rich. It began on a small scale, with boys only, to a worldwide system that speaks to the hearts and lives of all youth, galvanizing the forces to remember and practice in their daily lives the awesome responsibility enjoined in the Adventist Youth Aim, "The Advent Message to All the World in My Generation."

The Brooklyn Temple Seventh-day Adventist Church has produced many great 
leaders from its "army of youth." Their influence has spread near and far, making significant contributions to the growth and development of the Seventh-day Adventist Church. It has not lost its vision of training and empowering youth to become actively involved in all aspects of the life of the church. The program it has tested and proved for the empowerment of its youth is described in chapter 4 . 


\section{CHAPTER IV}

\section{THE PROGRAM TO EMPOWER YOUTH}

Having examined the theology and history of youth ministry in the previous chapters, the focus of this chapter is to present and describe the program that was implemented at the Brooklyn Temple Seventh-day Adventist Church. This program was designed to empower its youth into full participation in the ministry and leadership of that congregation. It was to assume the process of training, mentoring, positioning and liberation-the ultimate prescription for success in the empowerment of youth.

The stark reality is that before an individual is brought into any form of leadership, there must be intentional training of that individual; to ensure that leadership responsibilities are executed in a manner that meets the expectations of the local congregation and preserves the high standards required by like congregations.

There is much support for empowerment according to the sentiments expressed in the Pastor's and Elder's Handbook for Youth Ministry:

While there is to be an active Adventist Youth Society in every church, it is important that the youth program not be isolated from the rest of the church. In addition to their participation in the youth organization, the young people should be integrated into responsible leadership and involvement in the entire church program. There should be young elders, young deacons and deaconesses, et cetera, working with experienced 
church officers. In all lines of church work the youth should be active ...Young people feel committed to a church where they feel needed, valued and respected.'

The program was conducted over a one-year period, ${ }^{2}$ covering a wide range of seminars. As the appendix will show, these seminars were intended to give to the youth a well-rounded understanding of the church, its doctrines, its mission, its message and the way it is managed from a leadership perspective. The program was not intended to be exhaustive or final. It was intended to whet and stimulate the appetite of the youth for desiring to know more and maturing into spiritual stalwarts in the church. This was to be a journey-a constant journey towards self-actualization and longevity in effective leadership by the youth of the church.

After twenty-four years of being a pastor, I have personally observed that a church will rise no higher than the vision of its spiritual leader-the Pastor. My experience has confirmed the adage, "so goes the Pastor or spiritual leader, so goes the church." Ellen White was right when she observed, "The converts generally come up no higher than the

${ }^{1}$ General Conference of Seventh-day Adventists Ministerial \& Youth Departments, Pastor's \& Elder's Handbook for Youth Ministry (Silver Spring, MD: General Conference of Seventh-day Aventists, 2002), 47.

${ }^{2}$ The program is referred to in three timelines: one year on page 63 , seven months on page 85 and, four months indicated in the Program Schedule in the Appendix. The seven and four-month periods are inclusive of the one-year timeline. The church began to be prepared for this program one year before its formal commencement. There was a week of prayer particularly designed to begin creating the environment and atmosphere for the implementation of the program, sensitizing it for effective ministry to youth, for youth and by youth. The church board, and subsequently the church in business session, voted to adopt the program three months before the actual seminars started. The program could not have begun without the blessings and approval of the church. Finally, the actual program lasted for four months, ending with a special service of celebration. 
standard raised for them by their ministers."

This program could not have gotten off the ground without the blessing and committed participation of the church pastor, Pastor Brian L. Carter. I approached him with the concept of empowering the youth of his congregation through training, mentoring, positioning and liberation. He was totally and unconditionally supportive of the program. Hence, it was easy for the church board to give the program positive approval and vote; to see it conducted through to fruition. The members in a business session gave their assent also. Then, the program began. With the knowledge that the entire church was in full support of a program designed to empower its own young people-its own children, sons and daughters, we started with confidence.

Brooklyn Temple was chosen because of its general history as a church with a culture that had a bent to promote successful youth ministry. The writer of this project was keenly aware of this and therefore made good on the approach to initiate this program. There was a comfort level present, and in informal interviews with several thought leaders in the congregation; it was evident that if such an initiative were to be conducted, it would receive positive support. It was in that broad context of support that Brooklyn temple became the laboratory for the program to empower its youth through training, mentoring, positioning and liberation.

'Ellen G. White, Testimonies for the Church, 9 Vols. (Boise, ID: Pacific Press Publishing Association, 1948), 445. 


\section{The Empowerment}

The word empower, defined by the.Webster's Glencoe Edition of The Random House College Dictionary, means "to give official or legal power or authority to."1

The Bible is replete with the empowerment motif. Acts 1:8 is pivotal in this regard, "And ye shall receive power after that the Holy Ghost is come upon you and ye shall be witnesses unto me both in Jerusalem, and in all Judea, and in Samaria, and unto the uttermost parts of the earth." Empowerment is not experienced by our exposure to a knowledge of science, literature, history, theology, nor even in the understanding of the Bible. Spiritual empowerment comes from and through the Holy Spirit.

The prophet Joel predicted the descent of the Holy Spirit upon the old and the young in Joel 2:28, 29: "And it shall come to pass afterward, that I will pour out my spirit upon all flesh; and your sons and your daughters shall prophesy, your old men shall dream dreams, your young men shall see visions; and upon the servants and upon the handmaids in those days will I pour our my spirit."

A vision can be received anytime and anywhere, while a dream only comes during sleep. God intends to empower the youth every moment of their waking and sleeping hours. He also knows that the older one gets the more likely the need for more sleep which increases the possibility for dreaming. Hence, God is specific regarding the empowering of youth along a visionary path. As already mentioned in previous chapters,

'The Random House College Dictionary (1991), s.v. "Empowerment." 
the Bible is replete with stories of empowered youth who made a significant difference in the lives of those with whom they were called to lead.

The descent of the Holy Spirit was experienced in a dramatic measure on the Day of Pentecost. This signaled the inception of the early Christian church. That experience was called the early rain, "The outpouring of the Spirit in the days of the apostles was the beginning of the early, or former rain, and glorious was the result." 1 The former rain was glorious, but, the latter rain will even be greater. Some are even experiencing it already and many will experience it in times ahead.. This will come in a greater measure as we come closer to the end of time:

But near the close of earth's harvest, a special bestowal of spiritual grace is promised to prepare the church for the coming of the Son of man. This outpouring of the Spirit is likened to the falling of the Latter rain; and it is for this added power that Christians are to send their petitions to the Lord of the harvest in the time of the Latter rain. ${ }^{2}$

Our youth will be a part of this spiritual revolution. Pentecost II is waiting to happen.

The empowerment began in earnest with the training seminars. It is important to give of the best to the youth if we will make a lasting impact on their lives and make them ready to assume leadership at all levels in the local church.

It has been proven that:

Youth are empowered by involvement. They need to take ownership of a program if they are going to care about it and be committed to it. Apathetic, unmotivated young people are usually those who have never been given an opportunity to become actively involved in the life of their

${ }^{1}$ White, The Acts of the Apostles (Boise, ID: Pacific Press Publishing Association, 1911), 54-55.

${ }^{2}$ Ibid. 
church.

Trusting youth to take leadership and ownership is risky, because they will make mistakes. But just as Jesus was patient with the mistakes of His disciples as they learned to serve Him, so church leaders who are truly committed to discipling young people will be patient with them as they move through the learning process. ${ }^{1}$

That is what the Brooklyn Temple Seventh-day Adventist church did for the youth of its church.

\section{Training}

The seminars were conducted on Sabbath afternoons, two hours before the local Adventist Youth Hour, and on Wednesdays and Thursdays evenings between 7 and 9 O'clock. On Wednesday nights it became the format for the Wednesday night prayer meetings. This proved effective and a number of members attended to receive both the information and the illumination. There were officers and senior members also, who expressed a desire to join the program, so that they could share in the information and illumination as the youth. They were welcomed and embraced.

In the matter of the educational and learning styles, it was clearly observed that one shoe does not fit all. Therefore, the learning styles of each student was taken into account, so that the information, so needful for each one would be disseminated and received in a manner that would be compatible to and the realization of individual learning.

${ }^{1}$ General Conference of Seventh-day Adventists Ministerial \& Youth Departments, 42. 


\section{Learning Styles}

Professor Gane speaks to the issue of learning styles when he carefully asserts, "If you want to help young people learn you need to understand the processes of how they learn."

He continues:

Religious learning contrasts with other types of learning in that it deals with attitudes more than content. Therefore, special care and concern needs to be given to the types of skills you use in "teaching" young people. Values and attitudes are caught more readily than they are taught. Attitudes are affective, feeling oriented. They tend to be more hidden in nature and are learned from life experiences and family traditions. These values then become part of one's experiences and family traditions. ${ }^{2}$

Bernice McCathy in her article, in the October issue of Educational Leadership, presents and elaborates on the types of learning styles inherent in our children and youth.

She suggests that there are four:

1. The imaginative learner who learns by feeling, creative activity and by sharing in small groups.

2. The analytic learner who enjoys lectures, talks and taking notes.

3. The common sense learner who learns by practical applications and

4. The dynamic learner learns by doing-involving one's self in the complete learning process. ${ }^{3}$

The methods adopted in conducting the seminars were diversified: the power

'Gane, Building Youth Ministry, 26.

${ }^{2}$ Ibid., 25.

${ }^{3}$ Bernice McCarthy, "Using the 4MAT System to Bring Learning Styles to Schools," Educational Leadership, October 1990, 31-37. 
point method of presentation, the lecture format, the chalkboard, the interactive, the explanation of theories and concepts, even philosophies packaged in handouts. These were some of the methods used to share the information needed to reach these young people.

\section{The Curriculum}

In order for the youth to be empowered in church leadership, they must be introduced to those seminars that will give information needed to perform at optimum, as often as one is called upon to do so. The curriculum below details those important seminars and presentations.

1. Church Heritage/The History and development of the Seventh-day Adventist Church:

This seminar spans the historical development of the Seventh-day Adventist Church prior to 1844 to the present time. It is of vital importance to any church leader. If one does not know the history of the organization he or she is a member of or are leading, that is a prescription for ineffectiveness.

2. The Twenty-seven Fundamental beliefs of the Seventh-day Adventist Church:

This is a study of the cardinal beliefs espoused by the Seventh-day Adventist Church. Like Church Heritage, this seminar was designed to bring the youth into a greater knowledge of what the Bible teaches and to give them a reason for their faith. Using all the possible methods available, this was accomplished. 
3. Church Leadership and Administration:

This seminar presented the challenging claims upon leaders in the understanding of leadership styles and personalities and introduces them to the interpretation and understanding of the Seventh-day Adventist Church Manual.

4. Personal Evangelism:

This seminar focused on personal strategies and approaches in reaching individuals with the everlasting gospel. Youth were prepared to share their faith on a one-to-one basis.

5. Effective Meeting Procedures:

This seminar is an extensive study of the conduct of meetings and sessions of the church. The General Conference Rules of Order was used and interfaced with Roberts Rules of Order to effect a clear understanding of parliamentary procedures.

6. The Gift of Prophecy in the Seventh-day Adventist Church:

Although included in the twenty-seven fundamental beliefs, this seminar focused in more detail on the call, life and ministry of Ellen G. White in the development of the Seventh-day Adventist Church.

7. The Doctrine of Health Reform:

This doctrine is one of the special doctrines taught by the Seventh-day Adventist Church.

The purpose of this.seminar was to focus on the health principles advanced in 
Scripture and those of the Health reform Message given to the Seventh-day Adventist Church in June 1863. The NEWSTART concept was highlighted.

8. Worship and the Services of the Church:

This seminar focused on worship from a biblical perspective and how the various approaches to worship have impacted the way we enjoy or not enjoy church services today, especially the young. Several models were looked at to broaden the exposure to other non-traditional and traditional worship styles.

9. Basic Computer:

This is an ongoing seminar, for it takes time to develop the skills in computer literacy. This is hoped to provide a general exposure to the computer and its functions within the context of modern technology and availability and access to the information in cyber space. For any church leader to function at optimum in this, the twenty-first century, one must own and be able to operate a computer.

10. Sermon Preparation and Delivery:

This seminar presented a study of the mechanics of sermon preparation and delivery. The kinds of sermons, kinds of delivery and the sermons of notable preachers were examined. Each student was given an opportunity to preach at least one sermon.

11. Youth Ministry and its importance in the Seventh-day Adventist Church:

This seminar introduced the leaders-in-training to the theology and practice of youth ministry. It was intended to allow these youth leaders to develop a philosophy of 
youth ministry, based upon a theology of youth ministry and then highlight and explain the various levels and segments of youth ministry in the Seventh-day Adventist church.

12. The Doctrine of the Sanctuary:

Although covered in a general way during the teaching of the twenty-seven fundamental beliefs, this subject was dealt with in details. Because of its importance, Ellen G. White comments "This is to be the foundation of every discourse given by our ministers." It is the foundation of our faith. This will enable the youth leaders-intraining to develop and have a greater appreciation for this cardinal doctrine of the church and to forge a deeper personal relationship with Jesus.

13. Christian Stewardship:

This seminar focused on our accountability to God as the Owner in relationship to us as managers of His bounteous blessings. Although dealt with in the twenty-seven fundamental beliefs, extensive treatment of the subject needs was done, so leaders can have more practical and hands-on understanding of the doctrine of stewardship.

After the youth-leaders-in training have had their training in the fundamentals to fit them for leadership in the local church, they need to be mentored, positioned, and liberated to do the work.

'Ellen G. White, Gospel Workers (Washington, D.C.: Review and Herald Publishing Association, 1948), 315. 


\section{Mentoring}

After reading the book, Sit Down 'Till You're Thirty-five, I became convinced that for any organization to have longevity and make a lasting impact on the home, school, church and society, it must involve its youth in positions of leadership. This is essential so the youth can be trained to fill positions of responsibility, which will provide continuity in leadership.

Mentoring has its roots in the story of Homer's Odyssey of Odysseus:

The King of Ithaca had to fight in the Trojan War. He left the care of his household to Mentor, teacher and overseer of Odyssey's son, Telemachus. After the war, Odysseus was condemned to wander vainly for ten years in his attempt to return home. In time, Telemachus, now grown, went in search of his father. Telemachus was accompanied on his quest by Athena, goddess of war and patroness of the arts and industry, who assumed the form of Mentor. Eventually, father and son were reunited, and together they cast down would-be usurpers of Odysseus' throne and Telemachus' birthright. In time, the word mentor became synonymous with trusted advisor, friend, teacher, and wise person.... Mentors are those special people in our lives who, through their deeds and work, help us to move toward fulfilling that potential. ${ }^{2}$

In Intensive Caring: Practical Ways to Mentor, one of Group's bestsellers, a

comprehensive definition for mentoring is cited:

Mentoring is the process by which an older leader invests his or her life into a younger, emerging leader for the purpose of spiritual character and leadership development in an intensely relational fashion. Mentoring is not an end in itself; rather it's a process, a means by which students can

${ }^{1}$ Gary Swanson, Sit Down 'Till You are Thirty-five, (Riverside, CA: La Sierra University Press, 1994), 80.

${ }^{2}$ North American Division Pathfinder Ministries, Pathfinder Leadership Awards Manual (Silver Springs, MD: NAD Office of Pathfinder Ministries, 1995), 72. 
be equipped and empowered to develop dynamic lives and ministries that are uniquely theirs.'

The Greek verb, mimeomai is the most frequently used Greek verb to explain the concept of mentoring. It calls for imitation rather than recitation. The English word, mimic, is derived from it. It means to act like someone rather than merely quoting him or her. In 1 Cor 4:15-17, the Apostle Paul admonishes, "I urge you to imitate me. For this reason I am sending to you Timothy. ... He will remind you of my way of life in Christ Jesus." In 1 Thess 1:6, Paul again describes the church as "imitators of us." The writer of the book of Hebrews admonishes, "Remember your leaders, who spoke the word of God to you. Consider the outcome of their way of life" (Heb 13:7).

Mentoring requires a level of vulnerability, risk-taking and openness. Many youth ministry professionals and those of other disciplines have come to realize, "that kids aren't put on hold until some magic age at which they can contribute to ministry. We mentor to build leaders, not just to offer some souped-up disciplining ministry."2 This essentially says that the mentor will do everything in his or her power to equip another person or group to properly carry out the functions of one's professional or voluntary responsibilities in such a way that the mentor can sit back and watch the mentee function without being jealous, covetous or feeling threatened. This is the reason for the process of mentoring, with a view to being fully equipped and empowered is in four phases: First,

${ }^{1}$ Barry St Clair, and Tony Martin, "Equipping Teenagers to do Ministry: Investing in the spiritual Leaders of the Future." quoted in Intensive Caring: Practical Ways to Mentor Youth (Loveland: Group Publishing, Inc., 1998), 31.

${ }^{2}$ Ibid., 33. 
the Mentor performs the task, while the mentee watches. Second, the Mentor does the task while the mentee helps. Third, the mentee does the task, while the mentor helps. Fourth, the mentee does the task, while the mentor watches. This is the model I have implemented in this program. However, I am keenly aware that there are others who are using this model as well.

In his instructive book on teaching the art of golfing, the father and mentor of arguably, the world's greatest and one of the youngest golfers, Tiger Woods, informs us that "Children learn by observation and imitation. Tiger would sit in his high chair in the garage and watch me hitballs into the net. Before I knew it, he was imitating my golf swing."1

He continues to focus on the fact that mentoring has a practical, hands-on side to it:

The best way I have found to work with children is to offer a challenge. Children respond readily to challenges. "Let's see how good you are?" You must be a little roughish, intentionally losing a game every now and then, because-let's face it-your skill level will probably be greater than theirs in the beginning. But I assure you, it is inevitable that they will eventually be better than you, just as Tiger became better than I. ${ }^{2}$

The challenge therefore is for mentors not to be afraid or feel threatened by the sharp minds and keen intellects of mentees. Mentors must be willing to release power to the mentees, thus becoming powerful themselves. A mentor must be self-assured, broadminded, self-defined and self-discovered in order to be effective. This is what the

\footnotetext{
'Earl Woods, Training a Tiger (New York: Harper Collins Publishers, 1997), 15. ${ }^{2}$ Ibid., 22, 23.
} 
program emphasized and challenged the older members of the church who have the task of being mentors for the leaders-in-training, to exercise those mature qualities that will help the youth to be their best.

In his article, "Be Sure to leave the Light On!" R. Leslie Holmes writes and makes a clarion call to intentionally mentor a new generation of Christian leaders. He alludes to Coca Cola's incredible rise in popularity and financial worth to Robert Goizueta, and dubs him the "driving force at the helm." He informs, "When Goizueta suddenly died from complications with lung cancer, Coca-Cola's stock barely flinched on Wall Street."1 He continues to admit that:

When the final tally of his reign as Cola King, Robert Goizueta's single greatest contribution to his organizatiomay well not be seen to have been his contribution to the bottom line but rather that he remembered his own mortality. For this reason, he mentored a cadre of potential successors that by some estimates runs four deep. As a result, even if some unforseen tragedy removes Douglas Ivestor, Coca Cola's new leader, there are still Goizueta-trained leaders to step in on short notice. Mr. Goizueta demonstrated a lesson from which Christian leaders might well learn. In a real sense, he left his light on. His succession plan was implemented years before his death. He did everything in his power to guarantee that the business he led would not go dark with his passing. ${ }^{2}$

The process by which our youth become effective partners in ministry within the church can be mirrored after the likeness of the Coca Cola's model. Holmes continues his trend of argument when he raises our awareness:

How many times has the work of great leaders in the Lord's vineyard suffered when they passed from the scene because of an unwillingness, or 5.

'R. Leslie Holmes, "Be Sure to Leave the Light On!", Ministry, November 1998, ${ }^{2}$ Ibid. 
even an inability, to prepare for a seamless succession? In some denominations there is an unwritten assumption that the person who follows a strong leader will automatically be a short-termer. This reality is a personal, professional, and community tragedy that does nothing to advance the gospel. Indeed, to fail to prepare a new generation of leaders is almost like asking the church to die. Not to plan is to unwittingly conspire with the one who would close our open Bible and silence our preaching. It is to hinder the teaching and mission of the church in the next generation. ${ }^{1}$

The Bible cites a number of mentoring cases: Moses menored Joshua to be his successor, although Joshua was much older than the age of our youth today. Eli mentored Samuel and He became the Judge over Israel and later founded the schools of the prophets. Under God's direction, Samuel discovered David whom he anointed and mentored until he became king of Israel. Elijah mentored Elisha and left a double portion of his spirit upon him. Barnabas mentored Paul, who through a ripple effect mentored Timothy. Jesus was the master Mentor. He mentored His disciples and they successfully led out in the establishment and development of the early Christian church.

This is the concept that we embraced at the Brooklyn Seventh-day Adventist Church-making sure that the current and future generations are nurtured and prepared for leadership in the local church. For this to happen, as alluded to in previous chapters, strong, trusting relationships must be established.

Group concurs with this concept:

Because relationships make a serious difference in a young person's life, mentoring is an important part of any youth ministry program. The reasons are: 1 . Young people make better choices when adults mentor them. 2. Teenagers need close adult relationships and 3. Teenagers need adults to help them develop lifelong faith relationships with Jesus Christ.

'Ibid., 5-6. 
Mentoring is not an end in itself; rather, it's a process, a means by which students can be equipped and empowered to develop dynamic lives and ministries that are uniquely theirs. We define mentoring as the process by which an older leader invests his or her life into a younger, emerging leader for the purpose of spiritual character and leadership development in an intensely relational fashion. If we are indeed the body of Christ and a priesthood of believers, we should equip our teenagers as ministers. ${ }^{1}$

This is the purpose of the program. Everything needed is being done to effect the realization of our goal to make all youth of the Brooklyn Temple Seventh-day Adventist church intimately involved in its management, message, ministry and mission. To quote a Chinese proverb, "Tell me, I forget. Show me, I remember. Involve me, I understand." This is the ultimate equipping, mentoring and empowering model.

\section{Position}

Mentoring dictates that we must have a predictable chronology of terms to determine when we will begin to watch while the mentee does the work. If this is going to be possible, the mentor must have a time frame in which he gives up or recommends the mentee for his position. After the youth are mentored they need to be taken to the next level-they need to be positioned. The process will be flawed if it remains mentormentee for all times. There must come a time when the mentee assumes the position for which he/she is being prepared and works side by side with the mentor. The impression must never be given that the mentee will never reach the stage of full maturity to assume the position of the mentor, nor should the mentor serve ad infinitum giving the impression of indispensability. Therefore, the ongoing process of mentoring continues while the

${ }^{1}$ Group, 12, 31-32. 
youth-in-training is positioned into responsible assignments. That's where the concept of term limits come in. This is what Brooklyn Temple did to take the process of empowering her youth to the next level.

\section{Term limits}

If the church then, must survive, it must determine a time to position the mentee or someone with the potentials and capabilities, to carry out the responsibilities of an office. Whatever terms the organization may decide on, if we consider term limits for lay workers and church elected officials there are enormous benefits that can be gleaned: First, it will eliminate any possibility for abuse of power and feelings of superiority and indispensability. Second, it will lessen the need for overt and or covert politicking of incumbents and supporters, in order to preserve, protect and maintain their positions. Third, it will allow incumbents to plan and function strategically so that they can accomplish much within a given time, rather than trying to devise a protracted agenda that may span decades, simply because of an insatiable appetite to remain "in the driver's seat." Fourth, there will be a more conducive climate for the development of a greater number of leaders who will be able to rise to take the helm of leadership as soon as the time dictates. Fifth, when former leaders are easily accessible, they can offer valuable, counsel to those just coming in and make the work more successful.

There is much we can learn from American politics. The president of the United States, despite his popularity, business acumen or political wisdom, can serve for only 
two consecutive four-year terms. We need to take a page out of one of the greatest democracies of the world and learn that true success comes to an organization when it allows others to play a part in the shaping of its destiny. Is the secular, political world wiser and more advanced than the children of light?

The only way to stop the apathy that is evident in the behavior of our youth is to begin to effect the kind of positioning that will connect them into direct participation in the leadership and management of the church. This is what the Brooklyn Temple of Seventh-day Adventists is now doing.

\section{Liberation}

After we position the youth leaders, we need to go a step further-Liberate them into unfettered participation in every aspect of the organization's operation. The Webster's Dictionary defines liberate as "To free (a group or individual) from social or economic constraints or discrimination, especially arising from traditional role expectations or bias. Liberation is the gaining of equal rights or full social or economic opportunities for a particular group."'

Although one cannot become president of the United States before being at least thirty-five years old, When are youth eligible to serve in the US armed forces? It is when they are at least eighteen years old. Are they too young for the armed forces? Why does

'The Webster's Dictionary, s.v. "Liberation." 
America train them to fly stealth bombers worth billions of dollars? Why do they let them fly fighter bombers? Why do they allow them to plough through deserts and rugged terrain with army tanks equipped with the deadliest of combat weapons? It is because the U.S. government is convinced that youthfulness provides the greatest possibility for endurance, alertness and skill.

On the church front, how many of our youth are involved in giving direction in church leadership? It is embarrassing to admit that we have, in too many churches and organizations, made our youth spectators instead of players.

According to Gane, "Youth ministry is turning spectators into participants." If we continue in our current trend, many youth could remain immature and irresponsible instead of developing into positive, productive adults. There will be few youth to step into position when the need arises or the vacancy created. That's why Zouzes and Postner put it cogently, "Liberate the leader in everyone, and extraordinary things happen."2

Liberation means allowing the youth to fight in their own armor. A classic example of this is the story of David and Saul in the encounter with the Giant Goliath in 1 Sam 17. The mentee should not be a clone of the mentor, but should be allowed to develop his /her own leadership style and be comfortable with his own personality. Therefore, "it is the work of true education to develop this power, to train the youth to be

${ }^{1}$ Gane, Building Youth Ministry, 66.

${ }^{2}$ James M. Kouzes and Barry C. Postner, The Leadership Challenge (San Fransisco, CA: Josey-Bass Publishers, 1995), 20. 
thinkers, and not mere reflectors of other men's thoughts."1

Liberation does not mean irresponsibility or compromise. It involves standing up and defending truth at all cost, even if it will create discomfort and unrest. Liberation also means that the adult leaders of the church must understand that the youth will make mistakes in their early years of the execution of their leadership roles. They must be liberated to make mistakes-not deliberately, but occasionally. Once they understand this, they must determine to criticize less and encourage more, understanding their own vulnerability and possibility of making mistakes also. They must be liberated to fail, for leadership is more being than doing. It is out of failure that stepping stones are built for success. For truly failure is education if one learns from it. This is the atmosphere that was created to conduct the program of empowerment.

The importance of this is further highlighted in the comment of E.G. White:

The work that lies next to our church members is to become interested in our youth; for they need kindness, patience, tenderness. ... There ought to be those whose hearts are touched by the pitiable situation in which they are placed, and who realize that Satan is working by every conceivable device to draw them into his net. ${ }^{2}$

She continues, "Satan well knows that there is no other class that can do as much good as young men and young women who are consecrated to God. The youth, if right, could sway a mighty influence." ${ }^{\prime 3}$

The North American Division of Seventh-day Adventists met in an

${ }^{1}$ White, Education, 17.

${ }^{2}$ White, Counsels to Parents, Teachers and Students, 41.

${ }^{3}$ White, Messages to Young People, 25. 
unprecedented summit for the redirection of the church in San Diego, California in 1991.

After hours of praying and seeking the direction in which to go, an action was taken to effect necessary changes in its operation. This included admitting to the unreasonable way in which the church has treated her youth and the need to empower them now for full participation in the leadership of the church. The San Diego Covenant states:

We are servants of the body of Christ-the Seventh-day Adventist congregations and ministers in the United States, Canada and Bermuda. We have come from a variety of ethnic, gender, regional and generational experiences, yet we are united by the urgent need for the second advent of our Lord. We are deeply concerned about the local churches across North America. Most are not growing. There is a lack of warmth and inclusiveness. Large numbers of youth and young adults in their 30s are inactive. Outreach and service to the community is in danger of being lost in comfortable rituals. Needs are not being met. Families are at risk. Giving and volunteering are down. Local leadership often places a higher priority on maintenance than mission, and pastors become discouraged or exhausted. There is grave danger that the precious Advent message will not be passed to the next generation. We have honestly confronted the facts at this meeting, spent time on our knees pleading for an outpouring of the Holy Spirit, and worked together to construct consensus. We confess our own tendencies towards empire-building, turf conflict, and illinformed and unscriptural leadership styles.... We believe that our Lord is already working to refresh and reinvent His church.... We have come together around a vision of congregations strong in mission and demonstration of the power of the Holy Spirit. We commit ourselves to change; to formal and informal relationships networked into a support system to encouraged strong congregations. We pledge ourselves to pray and work together for the implementation of these hopes and dreams. ${ }^{1}$

The Brooklyn Temple of Seventh-day Adventists have demonstrated the intent of this covenant and have put in place the mechanism to empower all her youth and young adults.

${ }^{1}$ North American Division, A Shared Vision for God's People (San Diego, CA: NK, 191), 13. 
As we continue to liberate our youth, there must be a deliberate posture to show them that we care. Search Institute provides this recipe:

Listen to them. Be honest. Share with them strengths they admire. Delight in their discoveries. Share their excitement. Give them space when they need it. Be relaxed. Answer their questions or provide or suggest other resource to answer their questions. Use your ears more than your mouth. Keep the promises you make.... Ask for their opinions. Let them solve most of their problems. Praise more, criticize less. Accept them as they are. Let them teach you sometimes. Celebrate their firsts and transit them through a program of passage [emphasis supplied]. Love them, no matter what. Apologize when you've done wrong. ${ }^{1}$

On my first visit to the campus of Montclaire State College in New Jersey, I read the immortal poem of the sage and poet Ruskin, etched in a stone carving in the middle of the campus. This epitomizes what we need to do for our youth as we liberate them to assume the leadership of the church:

Therefore, when we build, let it be such as our descendants will thank us for; and let us think, as we lay stone on stone, that a time is to come when those stones will be held sacred, because our hands have touched them, and then men will say as they look upon the labor and the wrought substance of them, "See!, This our fathers did for us.""

The famous Chinese proverb instructs us, "If you are planting for a year, plant grain. If you are planting for a decade, plant trees. (But) if your are planting for a century, plant people."

The best people to plant as we face the twenty-first century are our children, youth Press, 1966).

'Search Institute, Ways to Show Teenagers You Care (Minneapolis, MN: Search

${ }^{2}$ Ruskin, found on a stone monument on the campus of the Mountclair State College, Mt. Claire, NJ: 1987.

${ }^{3}$ Given as a single-sheet hand out at a Youth Congress, held in Orlando, Fla, 1997. 
and young adults. Let's train, mentor, position and liberate them now to accomplish total empowerment for this, the most vital segments of our church, community and the world, our youth.

That is what the Brooklyn Temple of Seventh-day Adventists has been doing for its youth. They have understood the message of the SansKrit: "Yesterday is already a dream, and tomorrow is only a vision. But today, well-lived, makes every yesterday a dream of happiness, and every tomorrow a vision of hope." They have understood that yesterday is history, tomorrow is a mystery, but today is surety, utilize it. They have understood that yesterday is but a cancelled check, and tomorrow is just a promissory note. But today is cash, ready for use. They have placed their youth in positions of responsibility in all phases of church leadership. They are a model for churches who dare to take their youth to the next level.

The response of the Pastor, officers and members of the Brooklyn Temple Seventh-day Adventist Church has been overwhelmingly positive. The church believes that this program was long overdue and that it has been a great blessing to the entire church. A youth friendly church environment has been created. The youth have been positioned in every office of the local church and are ready to give quality leadership at all levels, now that they have been trained.

Chapter 5 focuses on the results of the evaluation, field testing and analysis of the program of empowering the youth of the Brooklyn Temple Seventh-day Adventist Church through training, mentoring, positing and liberation. 


\section{CHAPTER V}

\section{FIELD TESTING AND ANALYSIS}

As mentioned in the previous chapter, the task here is to analyze data collected from the program participants and give a reflective appraisal and evaluation to ascertain the effectiveness of the program.

The program lasted for seven months during which three instruments were used to measure responses to particular aspects of the curriculum. At the beginning, a Church Leaders-in-Training Pre-course Survey was administered to identify the areas of need It was used to discover their knowledge base in terms of the curriculum to be presented.

The three instruments used to measure responses to the program were the Church Leaders-in-Training Pre-course Survey given out before the course began, the Church Leaders-in-Training Post-course Survey and the evaluation which followed. (These instruments may be found in the Appendix.)

\section{The Church Leaders-in-Training' Pre-Course Survey}

Fifty-six people signed up on the initial day of the program. This number was sustained, over the period although some missed some presentations or parts of them. The interest was sustained and there were times when the entire church was present, 
especially on Sabbath afternoons. Seventy percent of the attendees were a combination of youth and youth leaders (10-35 age group). The remaining 30 percent were honorary members (36 and above age group) of the AY Society who came to show support for the program, receive added information and inspiration from the seminars, and serve as mentors to the young people.

In today's postmodern world, "as always, young people need the support of a Christian community and the guidance of mature Christians." " Among the 30 percent group were a number of mentors who were ready to invest their time, wisdom, and experience in assisting the young Leaders-in-Training to become the best.

Before the program began, mentors were selected by the pastor based upon his first-hand knowledge of their capabilities and were given instructions as to what their responsibilities would be. The pastor conducted two seminars preparing the mentors to take their role in the development of the youth. One program lasted for thirteen weeks and the other lasted for eight weeks. Among the criteria established for mentors, were the following:

1. They must be enthusiastic about the welfare of youth and the church.

2. They must have highly developed interpersonal skills.

3. They must share their interests and experiences with youth.

4. They must be role models, demonstrating admirable qualities and values and Christ-like characters.

5. They must have the gift of teaching so they can impart information, knowledge and skills.

6. They must be motivators, giving constructive feedback and encouraging independent thinking and action.

${ }^{1}$ General Conference of Seventh-day Adventists Ministerial \& Youth Departments, 14. 
7. They must be friendly, and demonstrate warmth and caring. ${ }^{1}$

These mentors were committed for the long haul to making sure that the youth leaders receive maximum support and guidance enabling them to reach their full potentials.

Sixteen questions were asked in the Church Leaders-in-Training Pre-course Survey. Based on a Likert-type scale, where 1 equals "least important" and 5 equals "most important," respondents in the program were to circle the number that reflected their thinking. They were also to indicate their age group: $10-15,16-22,23-35,36-40$, or 41 and above. Every question asked in the survey was followed up and satisfied by a seminar track presentation.

The first question asked, "How important do you think a course for training youth to be church leaders is?" One hundred percent responded that it was of highest importance. This was an indication of overwhelming support. It was also a clear statement that the church was ready to see its youth empowered in leadership.

The second question asked, "How well do you know and can explain the twentyseven fundamental beliefs of the Seventh-day Adventist Church?" Fifty percent of the registrants were not too familiar with all of the twenty-seven fundamental beliefs, 25 percent had a fair grasp of them, while the remaining 25 percent had very little knowledge. It was clear that the seminar on the doctrines of the church was greatly needed.

'Patrick Allen, Balvin Braham and Althea McMillan, "Mentoring Inspires Success," Youth Ministry Accent 1. (2003) : 30. 
The third question asked, "Do you think that the Church Board plays a vital role in the management and guidance of the church?" Eighty-four percent felt that the church board played a significant role in the management and direction of the church, but they had never had any experience serving on it. Sixteen percent felt that it was not so important. This is why the seminar on church leadership and management was vital.

The fourth question was asked, "How well do you know the history and development of the Seventh-day Adventist church?" Thirty-four percent said they knew nothing. Forty percent had some idea, while the remaining 26 percent believed they knew the subject adequately.

The fifth question asked, "How important, in your opinion, are church business meetings?" Sixty percent agreed that they were high in importance, while the remaining 40 percent were not as convinced. For many years as a church pastor, I have observed that few, if any, young members attend church business meetings. In my informal interviews with the youth, the majority said business meetings are adult meetings and what they say is not important because adults feel that they are the experienced ones and therefore have the last word. It is in these meetings, however, that the church makes decisions that affect the youth. This seminar was designed to highlight the importance of the business meeting as an integral part of the life of each member. It was also intended to show that youth must be present to be a part of the decision-making process to effect changes and to show that the possibility of adult intimidation must not be the sole reason 
for their absence from these important sessions of the church.

Because of the close relationship between the sixth and the seventh questions and the almost identical responses to each, I have combined the responses. The sixth question asked, "How. knowledgeable are you in the area of church leadership and management?"

The seventh question asked, "How knowledgeable are you on the subject of parliamentary procedures in relation to the conducting of meetings?" Fifty-two percent were not so sure that it was very important, while the remaining 48 percent felt that it was important. The seminar really emphasized the necessity for church leaders to understand how to properly conduct church meetings and how leadership affects the direction and ultimate success of an organization.

Since a leader could be called upon to preach or exhort the church at some time, the eighth question asked, "How do you feel about the prospects of learning the skills of sermon preparation and delivery?" Fifty-two percent felt that it was highly important to be equipped with the skills, while the other 48 percent felt that it was not highly important.

The ninth question was designed to awaken an interest in the need for leaders to not only be conversant with the Church Manual but to own one for their personal and leadership growth and development. Hence, the question asked, "How familiar are you with the Seventh-day Adventist Church Manual?" Fifty-six percent had no familiarity with it, while the remaining 44 percent had some knowledge of it. 
The tenth question was intended to identify their familiarity with the Spirit of Prophecy and that gift as expressed through the life and ministry of Ellen G. White. The question asked, "How well do you understand the Gift of Prophecy as manifested in the life and ministry of Ellen G. White?" Seventy percent indicated that it was important, while 30 percent indicated that it was highly important to have an understanding of the ministry of Ellen G. White and an understanding of the Spirit of Prophecy.

The eleventh question focused on the necessity for leaders to cultivate and develop the skills to give personal Bible studies. The question asked, "Do you have the necessary skills to give personal Bible Studies and lead a soul to make a decision for Jesus Christ and ultimate baptism?" Sixty-seven percent felt it was highly important to know and be able to implement this skill, while 33 percent did not see the importance of it.

The twelfth question asked; "How well do you understand the NEWSTART" lifestyle program of the Seventh-day Adventist Health Message?" Sixty-five percent indicated that they did not understand the program well, while 35 percent indicated that they understood the program fairly well.

The thirteenth question asked, "To what degree can you plan and conduct the worship services of the church?" Sixty-seven percent indicated that they did not have much information on how to conduct the worship services of the church, while 33 percent had a good idea of how to conduct the services of the church.

${ }^{1}$ The acronym NEWSTART represents the eight natural remedies for optimum health: Nutrition, Exercise, Water, Sunlight, Temperance, Air, Rest, and Trust in God. 
The fourteenth question asked, "How well do you understand the computer and its functions, including the use of the internet?" Seventy-three percent indicated that they did not know much about the computer and its functions, while 27 percent had a good knowledge of the computer and its functions.

The fifteenth question asked, "How well do you understand the history, development and growth of regional conferences and the need and reason for their existence?" Seventy-nine percent indicated that they did not know much about the history and development of the regional conferences, while 21 percent indicated that they knew about the history and development of Regional conferences.

The sixteenth question asked, "How much do you think church leaders should know about Youth Ministry in general and in the Seventh-day Adventist church in particular?" One hundred percent indicated that it was very important for church leaders to know about Youth Ministries in general and in the Seventh-day Adventist church in particular.

This initial fact-finding survey revealed significant information. In question 1 , it was evident that those present at the initial meeting were convinced that the course for training youth to become church leaders was necessary. That was pivotal for the course to begin in earnest-indicating full support for the program. It was also evident that those to be trained lacked a great deal of theoretical and hands-on experience in the areas indicated in the survey. This led to the need and validity for the training prograrti. 
It became an opportunity to prepare these leaders for leadership in the local church. One hundred percent positive response was indicated when asked, "How much do you think church leaders should know about Youth Ministries?" This was also indicative for the overall need of the church to become intelligent and informed regarding Youth Ministries.

\section{The Church Leaders-in-Training Post-Course Survey}

When the training was completed, it was necessary to conduct the Church Leaders-in-Training Post-course Survey to engage them in an evaluation of the program. In an effort to ascertain whether or not the primary objectives of the program were realized, this survey offered the sixteen pre-course questions in the form of statements that required the following responses: $1=$ strongly agree, $2=$ agree, $3=$ undecided, $4=$ disagree, and $5=$ strongly disagree.

There was a 1.00 percent response for strongly agree to the statement, "I believe that the church leaders-in-training course for youth is a must." Seventy-eight percent strongly agreed that they felt satisfied with their knowledge of the twenty-seven fundamental beliefs of the Seventh-day Adventist Church, while 22 percent were undecided. Because there will be ongoing classes conducted by the church pastor and the elders, the regular Bible Class will give added strength and build those who need further help to better understand the twenty-seven fundamental beliefs. I fully endorse the truism:

Never think that you have learned enough, and that you may now 
relax your efforts. The cultivated mind is the measure of a man. Your education should continue during your lifetime; every day you should be learning, and putting to practical use the knowledge gained. ${ }^{1}$

Eighty-four percent strongly agreed that the Church Board was an important administrative arm of the church, while 16 percent were undecided.

Eighty-four percent strongly agreed that they can now share with confidence the history and development of the Seventh-day Adventist Church, while 16 percent were undecided.

There has been a great and growing concern for the number of youth who attend church business (members) meetings. The concern has grown out of the reality that the youth feel that the church is an adult-run church, hence they do not have much, if any, voice at these meetings. One objective for this seminar was to help young people become aware of the need to be present at these meetings, assert their rights as legitimate members, and take a proactive part in the decision-making processes of the local congregation. Absence from these meetings only makes things worse. It was gratifying, therefore, to see that there was 100 percent response to the statement that they believed they had a deeper appreciation for and a better understanding of church business meetings, their purpose and how they were conducted.

Ninety-two percent strongly agreed that after doing the seminar on leadership in the Seventh-day Adventist Church, they believed they had a greater comfort level in assuming a leadership role in the church, while 8 percent were undecided.

${ }^{1}$ White, Testimonies for the Church, 4:561. 
Seventy-eight percent strongly agreed that they felt their skills in parliamentary procedures had been greatly sharpened since the seminar, while 22 percent indicated that they were undecided.

Eighty-four percent strongly agreed that they felt very comfortable in preparing and delivering sermons, while 16 percent were undecided.

Ninety-two percent indicated that they strongly agreed that they felt they had a greater understanding of and appreciation for the importance of the Seventh-day Adventist Church Manual, while 8 percent were undecided.

Ninety-two percent strongly agreed that they felt that had a greater appreciation for and an understanding of the life and ministry of Ellen G. White, while 8 percent were undecided.

Ninety-two percent strongly agreed that they were more comfortable in giving personal Bible Studies with a view of leading a soul to Jesus Christ and an ultimate decision for baptism, while 8 percent were undecided.

It was refreshing to observe that 100 percent strongly agreed that they had a greater appreciation for the legacy of the health message given to the Seventh-day Adventist Church.

Ninety-two percent indicated that they strongly agreed that, after the seminar on how to conduct the services of the church, they can now plan and help others plan for and conduct the various worship services of the church, while 8 percent were undecided. 
Fifty-eight percent strongly agreed that they felt comfortable with their understanding of the computer and the success it provided in the management of their daily lives, while 42 percent were undecided. The Brooklyn Temple provided a staff of computer-savvy personnel to be responsible for the training, and they continue to hold sessions for those who want to be knowledgeable in advanced computer skills.

Ninety percent strongly agreed that they had a greater understanding of and appreciation for the history and development of regional conferences, while 10 percent were undecided.

One hundred percent strongly agreed that to be a balanced church leader, one should understand all the areas of Youth Ministry at all levels.

The third segment of this chapter focuses on the evaluation that was conducted at the end of the training sessions and seminars. It was intended to further discover the effectiveness of the program.

\section{Evaluation}

Each person was asked six questions. The answers were to be given as completely as possible, and if there was need for additional paper to complete their answers, it would be made available.

The first question asked, "How would you rate this Leaders-in-Training program on a scale of $1-10,1$ being the lowest and 10 being the highest?" The average response was 9.5 out of 10 , in favor of the program. This is a highly positive response, in that it 
shows the vast benefits that individual members felt they received.

The second question asked, "What did you like the best?" One hundred percent liked the great detail of information in the training sessions and seminars. One hundred percent liked everything that was presented. They identified those seminars they liked most: worship and services of the church; the different personalities in leadership; the history of the Seventh-day Adventist Church; Black Heritage and the development of the regional conferences; the consistency of the presenters-they were always there and on time. The seminars, they admitted, were professional, yet down-to-earth, so that even a child could understand the information. (Examples of Seminar presentations may be found in Appendix A.)

The third question asked, "What did you like least?" Some said, it was not long enough. Some said, there was nothing they did not like, everything was good. Others said they needed more time, especially on Sabbaths, because the seminars sometimes ran into the Adventist Youth hour. Wednesday nights were OK.

The fourth question asked, "What improvements would you recommend for the next time?" Some said, "Get more young people involved." Someone indicated that there was no obvious need for improvement. One person hoped that more young people should be present to better understand their church and its function. Someone indicated that we had gone late in the night sometimes. Some said, "We should have better accountability for attendance at the seminars." Someone said, "There should be a more formal graduation and a special social event to culminate the program." Someone said, "We 
should start on time." The issue of time was of special note. When the people think that time should be better managed, it shed some light on the subject of individual responsibility and accountability. It also indicated the deep interest that was generated for the program.

The fifth question asked, "Would you recommend this program to the entire Northeastern Conference?" The answers were 100 percent, yes. They indicated that it enabled them to better understand their church and its function. They also received information about their heritage that they did not know before. They felt that the program would bring out hidden talents in the members.

As previously mentioned, in order to show unqualified support for the program, the pastor of the church volunteered to facilitate in some of the seminars. I was present at every seminar he facilitated, ensuring that the program was conducted as planned.

The sixth question asked, "Did the facilitators do justice to their presentations?" The answers were a resounding, yes. They expanded their answer admitting that the facts were fundamental and Bible-based. They continued that the presentations were well put together and the presenters were excellent. They further indicated that the presenters were knowledgeable, animated, interesting, and passionate about what they were doing. They indicated that the presenters were interesting and informative. They said that the presenters were well prepared. They remarked that the presenters had sufficient handouts and had enough references to support their presentations. They supported the fact that the 
presenters knew their material very well and were prepared for each presentation.

There is much information to be gleaned in comparing and contrasting the responses before and after the seminars were conducted. Before the seminars began, 100 percent of the Leaders-in-Training believed in the program to prepare youth for church leadership. After the seminars were finished, the same sentiments remained at the same level.

Before the seminars began, 50 percent knew and could explain the twenty-seven fundamental beliefs, while, 25 percent had a fair knowledge and the remaining 25 percent had very little knowledge. After the seminars were finished, 78 percent felt they could explain the twenty-seven fundamental beliefs, while 22 percent had a fair knowledge and indicated that in time as they attended post-program Bible classes, they would have a better understanding of them.

Before the seminars began 84 percent of the registrants felt that the church board played a vital role in the management and direction of the church, while sixteen percent were unsure. After the seminars, 84 percent felt they had a greater understanding of how the church board works and would be comfortable serving on it. There was no real change here, but the fact is that there was a sustained position taken by these registrants.

Before the seminars, 34 percent felt they had an excellent knowledge of the history and development of the Seventh-day Adventist Church, while 40 percent felt they had some knowledge and 26 percent had very little knowledge. After the seminars, 84 
percent felt that they could share with confidence information concerning the history and development of the Seventh-day Adventist Church, while 16 percent were undecided.

Before the seminar, 60 percent of the registrants felt that business meetings were necessary and important, while 40 percent did not see their importance. After the seminar, 100 percent felt a deeper appreciation for and a better understanding of church business meetings.

Before the seminar, 52 percent felt they were knowledgeable in the area of church leadership and management, while 48 percent were not. After the seminar, 92 percent had a greater comfort level in assuming a leadership role, because of a greater understanding of church leadership, while 8 percent were undecided.

Before the seminar, 52 percent understood the subject of parliamentary procedures in relation to conducting meetings, while 48 percent did not. After the seminar, 78 percent indicated that their skills in parliamentary procedures have been greatly sharpened, while 22 percent were undecided.

Before the seminar, 52 percent indicated that they felt a desire to learn the skills of sermon preparation and delivery, while 48 percent were not sure of its importance. After the seminar, 84 percent strongly agreed that they could prepare and deliver a sermon, while 16 were undecided.

Before the seminar, 56 percent had a familiarity with and an understanding of the Seventh-day Adventist Church Manual, while 44 percent did not. After the 
seminar, 92 percent strongly agreed that they had a greater understanding of the use and function of the Seventh-day Adventist Church Manual, while 8 percent were undecided.

Before the seminar, 70 percent had an understanding of the Gift of Prophecy manifested in the life and ministry of Ellen G. White, while 30 percent did not. After the seminar, 92 percent had a greater understanding of and an appreciation for the Gift of Prophecy, while 8 percent did not.

Before the seminar, 67 percent felt they had the skills necessary to give personal Bible studies and lead a soul to make a decision for baptism, while 33 percent did not. After the seminar, 92 percent indicated they felt comfortable to give personal Bible Studies with a view of leading a soul to Jesus Christ and an ultimate decision for baptism, while 8 percent were undecided.

Before the seminar, 65 percent understood the NEWSTART lifestyle program of the Seventh-day Adventist health message, while 35 percent did not know. After the seminar, 100 percent understood and appreciated the legacy of the health message to the Seventh-day Adventist Church.

Before the seminar, 67 percent understood how to plan and conduct the worship services of the church, while 33 percent did not. After the seminar, 92 percent understood, while 8 percent were undecided.

Before the seminar, 27 percent had a working knowledge of the computer, while 73 percent did not. After the seminar, 58 percent were more 
comfortable with their understanding of the computer and its benefit in making their work easier, while 42 percent were undecided.

Before the seminar, 21 percent felt they understood the history, development and growth of the Regional Conferences, while 79 percent did not. After the seminar, 90 percent understood, while 10 percent were undecided.

Before the seminar, 100 percent felt that church leaders should have a thorough knowledge of Youth Ministry in general and the Seventh-day Adventist Youth Ministry in particular. After the seminar, 100 percent shared the view that every church leader should understand all there is about Youth Ministry in general and Seventh-day Adventist Youth Ministry in particular.

It is abundantly clear that the program was a great success and that the trained church members, especially the youth-the primary focus of this program (See Table 1.) is to make a continuous positive contribution to the growth of the church.

Presently, a number of youth occupy key positions in the Brooklyn Temple Seventh-day Adventist Church. The program of empowerment has and will continue to occupy a prominent place in the Brooklyn Temple Seventh-day Adventist Church. The church has developed and now fosters and encourages a youth-friendly church environment. It encourages full participation of youthful talent, energies, and abilities in the leadership of the church. Mentoring is on-going. Youth are allowed to be creative and to conduct their ministries in a manner where they are not always expected to 
TABLE 1

A COMPARISON OF THE RESPONSES OF THE PRE-AND POST-COURSE

SURVEY

\begin{tabular}{|c|c|c|c|c|c|c|}
\hline $\begin{array}{l}\text { Pre-course } \\
\text { Questions }\end{array}$ & $\begin{array}{l}\text { Percentage } \\
\text { least } \\
\text { importance }\end{array}$ & $\begin{array}{l}\text { Percentage } \\
\text { fair } \\
\text { importance }\end{array}$ & $\begin{array}{l}\text { Percentage } \\
\text { high } \\
\text { importance }\end{array}$ & $\begin{array}{l}\text { Post-Course } \\
\text { Survey } \\
\text { Statements }\end{array}$ & $\begin{array}{l}\text { Percentage } \\
\text { Strongly } \\
\text { agree }\end{array}$ & $\begin{array}{l}\text { Percentage } \\
\text { Undecided }\end{array}$ \\
\hline $\begin{array}{l}\text { Question } \\
1\end{array}$ & 0 & 0 & 100 & $\begin{array}{l}\text { Statement } \\
1\end{array}$ & 100 & 0 \\
\hline $\begin{array}{l}\text { Question } \\
2\end{array}$ & 25 & 25 & 50 & $\begin{array}{l}\text { Statement } \\
2\end{array}$ & 78 & 22 \\
\hline $\begin{array}{l}\text { Question } \\
3\end{array}$ & 16 & 0 & 84 & $\begin{array}{l}\text { Statement } \\
3\end{array}$ & 84 & 16 \\
\hline $\begin{array}{l}\text { Question } \\
4\end{array}$ & 26 & 40 & 34 & $\begin{array}{l}\text { Statement } \\
4 \\
\end{array}$ & 84 & 16 \\
\hline $\begin{array}{l}\text { Question } \\
5\end{array}$ & 40 & 0 & 60 & $\begin{array}{l}\text { Statement } \\
5 \\
\end{array}$ & 100 & 0 \\
\hline $\begin{array}{l}\text { Question } \\
6\end{array}$ & 48 & 0 & 52 & $\begin{array}{l}\text { Statement } \\
6\end{array}$ & 92 & 8 \\
\hline $\begin{array}{l}\text { Question } \\
7\end{array}$ & 48 & 0 & 52 & $\begin{array}{l}\text { Statement } \\
7\end{array}$ & 78 & 22 \\
\hline
\end{tabular}




\begin{tabular}{|c|c|c|c|c|c|c|}
\hline $\begin{array}{l}\text { Question } \\
8\end{array}$ & 48 & 0 & 52 & $\begin{array}{l}\text { Statement } \\
8\end{array}$ & 84 & 16 \\
\hline $\begin{array}{l}\text { Question } \\
9\end{array}$ & 44 & 0 & 56 & $\begin{array}{l}\text { Statement } \\
9\end{array}$ & 92 & 8 \\
\hline $\begin{array}{l}\text { Question } \\
10\end{array}$ & 30 & 0 & 70 & $\begin{array}{l}\text { Statement } \\
10\end{array}$ & 92 & 8 \\
\hline $\begin{array}{l}\text { Question } \\
11\end{array}$ & 33 & 0 & 67 & $\begin{array}{l}\text { Statement } \\
11\end{array}$ & 92 & 8 \\
\hline $\begin{array}{l}\text { Question } \\
12\end{array}$ & 35 & 0 & 65 & $\begin{array}{l}\text { Statement } \\
12\end{array}$ & 100 & 0 \\
\hline $\begin{array}{l}\text { Question } \\
13\end{array}$ & 33 & 0 & 67 & $\begin{array}{l}\text { Statement } \\
13 \\
\end{array}$ & 92 & 8 \\
\hline $\begin{array}{l}\text { Question } \\
14\end{array}$ & 27 & 0 & 73 & $\begin{array}{l}\text { Statement } \\
14\end{array}$ & 58 & 42 \\
\hline $\begin{array}{l}\text { Question } \\
15\end{array}$ & 21 & 0 & 79 & $\begin{array}{l}\text { Statement } \\
15\end{array}$ & 90 & 10 \\
\hline $\begin{array}{l}\text { Question } \\
16\end{array}$ & 0 & 0 & 100 & $\begin{array}{l}\text { Statement } \\
16\end{array}$ & 100 & 0 \\
\hline
\end{tabular}

function using the traditional approaches. This is a part of the liberation strategy towards the full development of the abilities, talents, and gifts of the youth. 
The Testimonies of the Pastor, a Mentor, and a Youth

In his personal evaluation of the program, the Pastor of the Brooklyn Temple

Seventh-day Adventist Church, Pastor Brian L. Carter, expressed his own testimony at

the graduation exercises of the Leaders-in-Training Program. He indicated his deep

appreciation and overwhelming satisfaction for the success of the program:

Pastor Cleghorne, I am deeply grateful for the months you have spent with us here at Brooklyn Temple. This church has experienced an awakening and a revival such as we have not seen for a very long time. I have sat in many of your presentations and I can truly admit that I have been blessed, personally and professionally. Your presentations were deeply spiritual, informative, well researched and always had a biblical foundation. My young people have experienced a new day in their lives. I promise you that I will make sure that what you have taught us over this period of time, will not go unheeded. I promise, that I will make sure that all our youth who have been trained and other potential youth will be no more spectators, but indeed partners and players on the ministry team of this church. Already, I have asked a sixteen year-old young lady to be the Divine Service speaker for one of the Sabbaths in the month of September. She is one of those that did an excellent sermon during the preaching clinic after you completed the seminar on Sermon Preparation and Delivery. Thank you for coming to Brooklyn Temple to empower our youth to be ready to take the helm of leadership in our church. May God continue to richly bless you. ${ }^{1}$

One of the mentors remarked,

I have been in this church for a long time, but I have never seen any thing like this. I have been truly blessed. My eyes have been opened to things, and information, I never had before. Continue Pastor Cleghorne. I trust that this program will be taken to all the churches in the

${ }^{1}$ Brian L. Carter, "An Appreciation Speech," presented at the occasion of the Service Celebrating Success for the Leaders-in-Training Program, The Brooklyn Temple of Seventh-day Adventists, Brooklyn, New York, July 7, 2002. 
conference. $^{1}$

One of the trained youth, a female, remarked,

I wasn't quite sure how this was going to sit with me, but after the first presentation, I realize that this was for me. I have received more than I expected. I feel that I can preach God's Word with boldness, now, especially after the seminar on Sermon Preparation and Delivery. I tell my friends from the other churches in Brooklyn and they hope that their church will do this for them too. God bless you Pastors Cleghorne and Carter. I desire to use my knowledge to bring many of my friends and associates to Jesus. ${ }^{2}$

Indeed, the Brooklyn Temple of Seventh-day Adventists has empowered its youth through training, mentoring, positioning. and liberation. Chapter 6 presents the summary, conclusions, and recommendations.

The pastor, the congregation, and especially the youth and mentors must be congratulated for this successful program conducted in the church. Remember, "only knowledge that is used sticks to the mind." By utilizing the information and learning how to function more effectively and efficiently, Brooklyn Temple (BT as it is otherwise called) is destined to become a pace- and a trend-setter. Ultimately, after all the youth have been empowered and all the adults are supporting and mentoring, the coming of Jesus will not only be imminent, but a reality.

1"“A Mentor's Response," presented at the occasion of the Service Celebrating Success for the Leaders-in-Training Program, The Brooklyn Temple of Seventh-day Adventists, Brooklyn, New York, July 7, 2003.

2"A Youth's Response,"presented at the occasion of the Service Celebrating Success for the Leaders-in-Training Program, The Brooklyn Temple Seventh-day Adventist Church, Brooklyn, NY, July 7, 2002. 


\section{CHAPTER VI}

\section{SUMMARY, CONCLUSIONS, AND RECOMMENDATIONS}

This final chapter presents the summary, conclusions, and recommendations that have become available based upon the study in the previous chapters. The task, therefore, is to paint the entire study into a comprehensive picture, come to the necessary and appropriate conclusions, and offer recommendations that will enable this study to be usable and transferrable. It is also intended that this study will serve as a launching pad to offer effective ministry to young people in the local church, conference, union, division, and ultimately the world.

\section{Summary}

The goal of this research project was to empower the youth of the Brooklyn Temple Seventh-day Adventist Church through the training, mentoring, positioning, and liberation processes. This need arose because of the obvious domination of adult members in the offices and positions of leadership in the local church. Young members have a sense of service to their church, but too often feel threatened and intimidated by the hovering influence of adult members. On the other hand, older members are sometimes mortified by the brilliance and knowledge base of the youth and feel that they will take their positions if they allow them to serve. 
That is why it was of paramount importance that we looked at what the Bible had to say about youth and youth ministry. We had to discover the theological underpinnings that made us take stock and review. The youth ministries professionals and authorities gave scholarly reflections and laid a solid foundation in support of authentic youth ministry. Indeed, youth ministry that is without a biblical and theological foundation will fall like the biblical "house on the sand" that came tumbling down.

Both the Old and New Testaments are replete with words and concepts that place the young in an enviable position. The Bible is clear, "Young people, I call upon you because you are strong." Samuel was probably the youngest prophet called by God-he was still a child. Josiah, probably the youngest king of all biblical times, was called when he was but eight years old. David was anointed as king long before he actually took the throne. He dared to challenge the Philistine giant, Goliath, whose head he later cut off and carried around the camp of the Israelites as a trophy of victory for the true God. Youth ministry is deeply embedded in and holds a significant place in the Bible.

One cannot but admit that the incarnational approach to youth ministry is the sine qua non of all approaches. It is the approach that informs us that we must build lasting and trusting relationships with young people if we are going to have an opportunity to influence them in the right direction-if we are going to see them saved. We must become vulnerable and be willing to take risks, because that is the world in which they live. As Jesus took a risk to save us in the incarnation, so we must take risks to save them. 
Adults must be awakened to the reality that the generation they are dealing with in the church today is of a different mind-set. They are wired to think and act out of the box, and do not necessarily always subscribe to the conventional and traditional approaches to doing ministry as their fathers and mothers of previous generations did. I am addressing here Generation $\mathrm{X}$ and the Millennials that are the largest population of youth in our church and society today. These youth do not want just a piece of the pie, they want to help make the pie. That is where participatory democracy looms largely to the surface. If we are going to make these youth players and not spectators, we must train them-deliberately and intentionally.

Training is key to the preparation of youth to assume legitimate leadership in the local church. We must not assume that because a young person is smart or thinks "twenty-first-century" that they are automatically ready for leadership roles. We owe it to them to rightly train them. We need to train them in all the areas of preparation for spiritfilled leadership. That is why the program was designed with a training component. In that exposure and discipline, the youth of the Brooklyn Temple of Seventh-day Adventists shone brilliantly in areas of church management and leadership, biblical and doctrinal soundness, historical development and growth of the church, in sermon preparation and delivery, in the art of bringing a soul to Jesus and the ultimate decision for baptism, the understanding of the broad concepts of youth ministry, and the importance of being computer literate in this the twenty-first century. 
We must go beyond training and we must mentor. If one has all the knowledge in the world and cannot translate that knowledge into practical living, that knowledge becomes useless. As it is often said, "If you do not use it, you lose it." After the youth were trained, there was a mentoring program established to ensure that the youth could get firsthand knowledge of how to function in the various areas of ministry. An adult was assigned to the youth for a period of time and that youth would work alongside the "pro" to see ministry in reality.

For any meaningful relationship to be established between adults and the young, they must come together in mutually beneficial experiences. That is why Althea $\mathrm{L}$. McMillan, Provost of the Northern Caribbean University (formerly West Indies College), highlights the need for the mentoring program:

Church leaders, as well as leaders in private and government enterprises, often forget their mortality, and do precious little to guarantee a "seamless succession." These leaders seem unaware of the personal, professional and community tragedy that results when "cadres of potential successors" are not mentored to ensure growth and continuity of effective programs [or organizations] [emphasis supplied]. Pastor Leslie Holmes refers to this deliberate training of future leaders as "leaving your lights on."

Church leaders at all levels must understand that Christianity is not an argument, or a performance. Rather it is an experience. The Christian must " $b e$ " kind, warm, generous, and gracious, giving all in service to others as Jesus did. We each need love and nurturing. And many of [y]our youth will find their rightful places in the church and society through an effective mentoring program. ${ }^{1}$

After having been in an effective mentoring program, the youth need to be placed

\footnotetext{
'Althea L. McMillan, Introduction to "Mentoring Inspires Success," Youth Ministry Accent 1(2003): 30.
} 
in positions of leadership. One cannot always be just learning to do something. There comes a time when that mentee needs to be in the driver's seat. Therefore, the church placed into key offices the youth who have been mentored. Their positions as officers of the church have placed them into the heart of the management and leadership of the church.

Now that they have been positioned, they need to be liberated, liberated to do ministry in a manner that goes to the heart of meeting human needs. Sometimes in meeting needs one has to become creative in order to be relevant. The youth have been allowed to do this, so that their service can reach beyond the borders of traditional expectations to truily get at the core of "scratching where it is itching."

The history of an organization is key to its continuous unfolding and vision. Therefore, the history of youth ministry in the Seventh-day Adventist Church and of the Brooklyn Temple Seventh-day Adventist Church, in particular, provided a meaningful backdrop to this project. The history of the Seventh-day Adventist Church gave the history of the Brooklyn Temple Seventh-day Adventist Church a springboard on which to launch a meaningful ministry to the youth. Having understood that the Adventist Youth Society was initially developed to provide opportunity for service and missions, it was very clear that the Brooklyn Temple Seventh-day Adventist Church would have to carry on this vision. After the congregation clearly understood that the Seventh-day Adventist Church was started by mostly teenagers, it became a wake-up call to the Brooklyn 
Temple Seventh-day Adventist Church that young people were indeed very important to the health and longevity of the organization. Therefore, the need to empower them into active participation in all aspects of church life became an imperative, not an option.

\section{Conclusions}

Having made the quality investment in time and preparation on this project at the Brooklyn Temple Seventh-day Adventist Church and its youth, it is abundantly clear and a notable fact that youth are an irreplaceable resource to the development, stability, and sustained growth and success of the organization.

I have seen the latent abilities and energies of the youth come alive and the demonstration of their capabilities to execute the challenging responsibilities devolving upon a local church.

Based upon the theological and biblical research conducted, as reflected in chapter 2, I am convinced that when youth are called upon to function in times of challenge and crises, they have the ability to rise, amidst the difficulty, equipped with strength, fortitude, and resilience to accomplish the task.

As I reflect on the work of the young pioneers of the Seventh-day Adventist Church and those of the Brooklyn Temple Seventh-day Adventist Church, I am convinced that the present and future of the church is in capable hands.

The program to empower youth is a major answer to the non-involvement, nonparticipation, and hemorrhaging of our youth in the local church. It provides the ultimate 
platform and environment for the continuous production of quality leaders that will take the church from the twenty-first century to the second coming of Jesus Christ.

\section{Recommendations}

After presenting the program of empowerment and seeing it to its implementation, I provided the results of the field testing and its analysis. I presented the summary and conclusions, now I present the recommendations.

I am keenly aware that there are other existing programs successfully geared to empower and mentor young people. However, I believe that this is the first of its kind. While others (for example, the Youth Apprenticeship Program developed and administered by the Pacific Union Conference, Church Ministries Department; the Master Guide Program and the Senior Youth Leadership Programs of the General Conference of Seventh-day Adventists) are designed to address specific areas of officer development or leadership to specific groups, this program is different from the others in that it specifically details a curriculum that is designed to train young people to take any leadership role in the church. It is designed to give a rounded and comprehensive preparation to take the youth to the next level.

Without hesitation then, I recommend this program to my local conference, the Northeastern Conference of Seventh-day Adventists. I believe that after it has been successfully implemented, the other church levels of the Union, Division and the General Conference will adopt it. 
I recommend this to all local congregations that have a youth-friendly church environment. I am aware of the fact that a program for empowering youth can cause uneasiness in the minds of adult leaders who desire to remain ad infinitum in positions of power and leadership. That is why it is so important that the local church pastor first sees and understands the vision and, by a deliberate process, builds support and cooperation among the church leadership structure to see this as the way of empowering our youth to feel ownership of their church.

I recommend this program to any congregation where youth are leaving the church because of non-involvement and where they have "spectator only" status. This would revitalize congregations and stop the hemorrhaging of our youth from the church.

Having considered the far-reaching implications for the future, identified in the Leaders-in-Training Post-course Survey and the subsequent program evaluation, I recommend that this program be conducted for a longer period of time than is presented here, in order to achieve greater participation and maximum results for the empowerment of our youth.

I recommend a more scientific survey that will quantify competency of the participants after the training sessions are completed.

I recommend a scientific survey that will more accurately demonstrate the recommendations of the survey.

I recommend a training manual for this program that will provide participants with a direct information base to more easily understand the various seminars presented. 
I recommend that this program be conducted on a continuous basis, empowering new leaders every year to be prepared to assume the helm of leadership in a cyclical rotation. This is a church-friendly program. It can therefore be done by the local church, led by the pastor, working with a steering committee, in consultation with the Conference Youth Director.

I recommend that there be a constant Bible class conducted with a new approach to reach the twenty-first-century technologically astute young mind. This is to ensure that the doctrinal-beliefs component of this program is not done just for the sake of satisfying the requirements of this curriculum, but that it becomes a way of life for each congregation, that implements this program.

I recommend that a special mentoring program be established in every congregation, where young people are constantly being developed by adult members of the church.

I recommend that when this program is being conducted in the local church or at any other level of the church, that there be no other program conducted simultaneously with it. For optimum results, this program must be conducted without distraction. I recommend that the issue of time management be considered seriously as the program is being conducted.

I recommend that any congregation conducting this program encourages an unswerving commitment, from all the potential leaders-in-training to give this exercise their full attention, during the duration of its operation. 


\section{5}

I recommend a formal graduation exercise based upon the financial capability of the church, followed by a gala event highlighting the importance of the program and support for its continuous operation.

Because of the urgency for the immediate execution of this program to regions near and far, I recommend that all pastors and elders and other thought leaders within the church community be summoned to a special meeting at various levels of the church, where the benefits of this program are explained and after clarification is ascertained, that the program begins as soon as possible in each congregation.

Programs are constantly being developed, plans are constantly being made, and decisions are taken every so often. But until programs, plans and decisions are implemented, and accountability entered in every facet of their operation, nothing will happen. These will only sit on paper, until they become just another casualty in the arena of academia and scholarship. This program to empower our youth through training, mentoring, positioning, and liberation must not become one of them. Our youth are too precious to be wasted.

The spotlight has been turned upon the Brooklyn Temple Seventh-day Adventist Church. The promise of the descent of the Holy Spirit in Joel $2: 28-31$ is being fulfilled. They are local elders, deacons, church musicians and choristers, Sabbath School superintendents, Personal Ministries directors, Family Life coordinators, hospitality coordinators, and youth leaders representing all levels of youth ministry. Just a few 
months ago one of the young men began preparing for full-time pastoral ministry at Southern Adventist University, one of the young ladies began preparing for Pastoral ministry at Oakwood College and another young man is contemplating becoming a minister of the gospel. An eighteen year-old is Assistant Superindent in charge of the Youth division of the Sabbath School.

Two years ago, there would have been some resistance to this program. Now it is an accepted philosophy of the church that youth must be trained in leadership. This was revealed in the recent composition of the Nominating committee, where six out of eight members of the nominating committee were under thirty-five, and the secretary of the committee was a seventeen year-old. The consciousness and direction of the church has changed and a greater commitment to this program of constant training of the youth is evident. If the pastor were to be transferred, this program would remain in tact, because of the strong desire of the church to see it remain as a program for continuous empowerment to the youth of the church.

But, beyond that, I see the Northeastern Conference, the Atlantic Union, and the North American Division, pioneering and piloting this program. I see thousands of young people on the streets, sharing their faith. I see thousands of individuals being baptized and becoming trained disciples immediately after baptism.

According to Chris Blake, former editor of Insight, "Adventist youth have been too long overentertained and underchallenged."1 Let's seize this moment and challenge

${ }^{1}$ Chris Blake, "Adventist Youth: Overtained and Underchallenged?," interview by Betty Kossick, Adventist Review, 8 July 1993, 10. 
them with this program.

Dr. Roy Adams was swept off his spiritual feet as he witnessed the outpouring of the Holy Spirit in the lives of a group of young men and women in Battle Creek, Michigan (Great Lakes Academy Seniors). What he saw at that year-end meeting of the North American Division of 1995 made him admit:

I saw a generation ready, under God, to take the ball from their lead-footed elders and the cynical among us, and run with it. Am I on the right track here? Or are we to consider it business as usual when academy kids fan out through the congregation, as these seniors did, to pray earnestly for leaders of the church and to affirm them? Is there something going here? I think so. Perhaps it's beginning to rain.'

As the rain falls, the ministry to empower our youth through training, mentoring, positioning, and liberation is a welcome answer supporting the active involvement, participation, and ownership in the church's leadership, mission, message and ministry. The youth are ready.

${ }^{1}$ Roy Adams, “Perhaps It's Beginning to Rain.” Adventist Review, December 12, $1995,5$. 
APPENDIX A

SEMINARS 


\section{Empowering through}

\section{TRAINING, MENTORING, POSITIONING \\ \&}

\section{LIBERATION}

by Pastor Newton U. Cleghorne

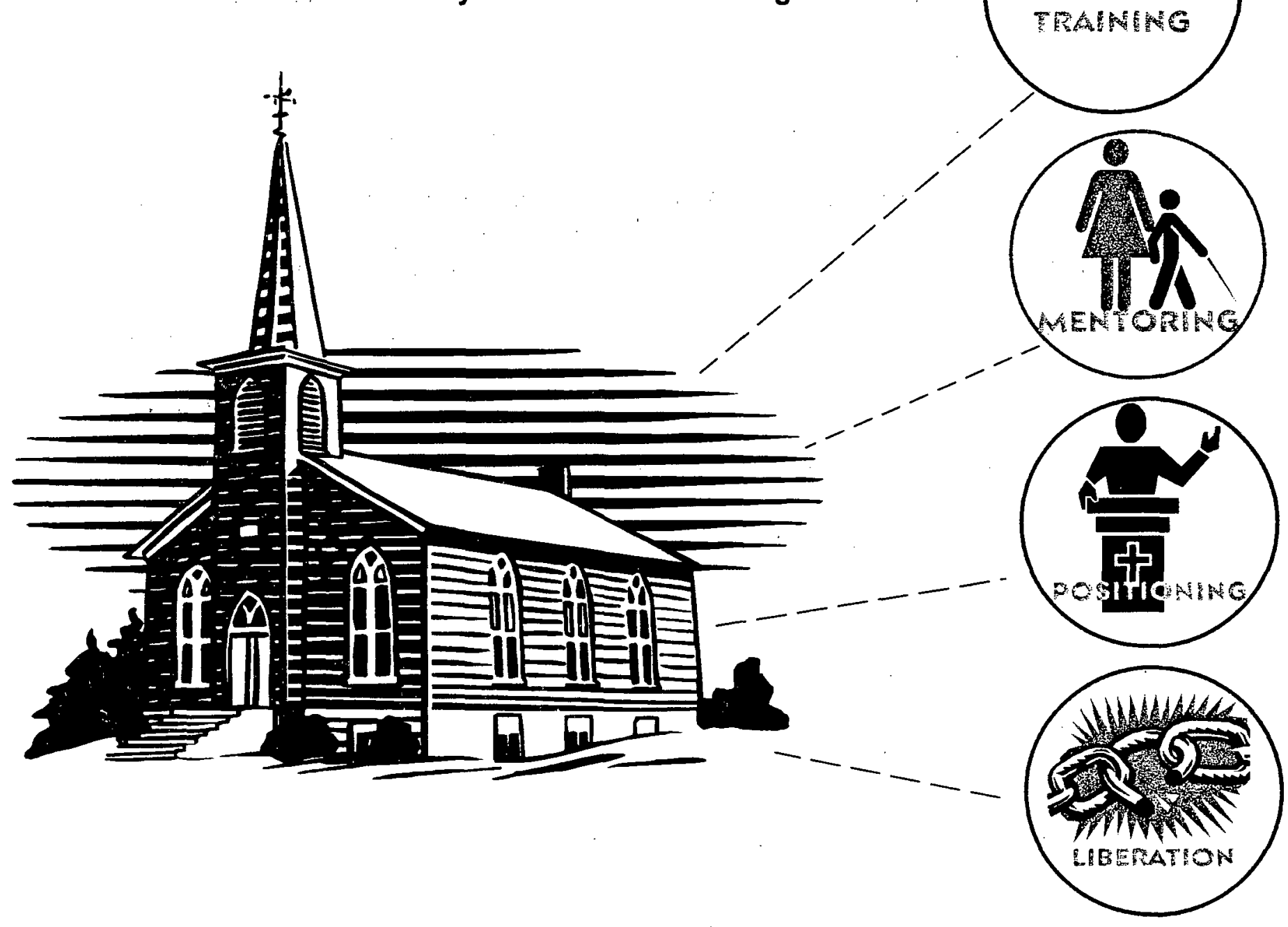

The primary goal is to train youth and all potential church leaders to lead the Seventh-day Adventist Church in the $21^{\text {st }}$ century and into the second coming of Jesus. 


\section{CHURCH LEADERS-IN-TRAINING PROGRAM}

The times demand that leaders and leaders-in-training be on the cutting edge of information, technology, new and innovative approaches to ministry in the local church and beyond.

The program is designed to empower youth in the local church and intentionally and purposefully prepare them for effective leadership. Ellen $\mathrm{G}$. White was right on target when she indicated, "With such an army of workers as our youth, rightly trained, might furnish, how soon the message of a crucified, risen, and soon-coming Savior might be carried to the whole world!"'

It is very clear to me that the church has an awesome responsibility to ensure that the youth be active participators in the leadership of the church. The program is intended to cover the key needs of leaders for the twenty-first Century. At the end of the course, there will be a graduation at which time those completing the course will receive special recognitions and certificates.

'Ellen G. White. Messages to Young People (Hagerstown, MD: Review and Herald Publishing Association, 1958), 196. 
If other officers of the church wish to take the course, they should be encouraged. This is a broad-based curriculum to satisfy the need for preparing our youth in a wellrounded manner to make them ready to give excellent service to their church and community.

\section{PROGRAM OUTLINE}

\section{The History and development of the Seventh-day Adventist Church}

Spans the development of the Seventh-day Adventist church prior to 1844 to the present

\section{The twenty-seven fundamental Beliefs of the Seventh-day Adventist Church.}

Presents a broad sweep of the twenty-seven fundamental beliefs of the Seventh-day Adventist Church. The text book is The 27 Fundamentals Beliefs

\section{Leadership and Church Administration}

Presents the challenging claims upon leaders in understanding leadership styles and personalities, and introduces the interpretation and use of the Church Manual.

\section{Personal Evangelism}

A study of personal strategies and approaches in reaching individuals with the everlasting gospel.

\section{Parliamentary Procedures}

An extensive study of the conduct of formal meetings and sessions of the church. The General Conference Rules of Order will be used to interface with Roberts Rules of Order to effect a clear understanding of parliamentary procedures.

\section{The Gift of Prophecy in the Seventh-day Adventist Church}


This study focuses on the call, life and ministry of Ellen G. Harmon-White in the development of the Seventh-day Adventist Church.

\section{The Doctrine of Health Reform}

This focuses on the health principles advanced in scripture coupled with the Health reform Message give to the Seventh-day Adventist Church, June 1863.

\section{Worship and the Services of the Church}

A careful look at worship from a biblical standpoint and how it is interpreted in the various styles today. Each service of the church will be dealt with.

\section{Basic computer}

This will provide a general exposure to the computer and its functions within the context of modern technology and availability and access of information on the Information Super Highway and access to the Adventist Online Services.

\section{Sermon Preparation and Delivery}

A detailed study of the mechanics of sermon preparation and delivery. The student will tap into homiletic resources and be given laboratory exposures to the sermons of the great preachers and pulpiteers of our time.

\section{Youth Ministry and it importance to the Seventh-day Adventist Church}

This study will introduce the leader-in-training to the theology and practice of Youth Ministry with a view to fully describe and explain the various levels and segments of Youth Ministry in the Seventh-day Adventist church. Some non-SDA models will be discussed. 


\section{The Sanctuary Doctrine}

Although this doctrine is covered in the twenty-seven fundamental beliefs, it is one of the cardinal beliefs of the Seventh-day Adventist Church. Emphasis will be made as it relates to the Investigative Judgement and our salvation.

\section{Christian Stewardship}

The need to be confronted with the biblical truth that we do not own anything, for God is the Ayner of them all. We are His managers and He expects us to be faithful stewards. 


\section{BROOKLYJN TEMPCE OJ SEVENTH-D.AY ADVENTISTS}

CHURCH LEADERS-IN-TRAINING SCHEDULE

\begin{tabular}{|c|c|c|c|c|}
\hline DATE & DAY & DURATION & CLASS & INSTRUCTOR \\
\hline \multicolumn{5}{|c|}{ MARCH } \\
\hline 02 & Sabbath & 3:30-5:00pm & Church Heritage & Pastor N. Cleghorne \\
\hline 07 & Thursday & 7:00-9:00pm & Church Heritage & Pastor N. Cleghorne \\
\hline 16 & Sabbath & $3: 30-5: 00 \mathrm{pm}$ & Church Heritage & Pastor N. Cleghorne \\
\hline 17 & Sunday & TBA & $\begin{array}{l}27 \text { Fundamental } \\
\text { Beliefs }\end{array}$ & Pastor B. Carter \\
\hline 21 & Thursday & 7:00-9:00pm & Church Heritage & Pastor N. Cleghorne \\
\hline 24 & Sunday & TBA & $\begin{array}{l}27 \text { Fundamental } \\
\text { Beliefs }\end{array}$ & Pastor B. Carter \\
\hline 28 & Thursday & 7:00-9:00pm & Church Heritage & Pastor N. Cleghorne \\
\hline 31 & Sunday & TBA & $\begin{array}{l}27 \text { Fundamental } \\
\text { Beliefs }\end{array}$ & Pastor B. Carter \\
\hline \multicolumn{5}{|c|}{ APRIL } \\
\hline 7 & Sunday & TBA & $\begin{array}{l}27 \text { Fundamental } \\
\text { Beliefs }\end{array}$ & Pastor B. Carter \\
\hline 11 & Thursday & $7: 00-9: 00 \mathrm{pm}$ & $\begin{array}{l}\text { Leadership \& Church } \\
\text { Administration }\end{array}$ & Pastor N. Cleghorne \\
\hline 13 & Sabbath & $3: 30-5: 00 p m$ & Personal Evangelism & Pastor B. Carter \\
\hline 14 & Sunday & TBA & $\begin{array}{l}27 \text { Fundamental } \\
\text { Beliefs }\end{array}$ & Pastor B. Carter \\
\hline 18 & Thursday & 7:00-9:00pm & $\begin{array}{l}\text { Parliamentary } \\
\text { Procedures }\end{array}$ & Pastor N. Cleghorne \\
\hline 20 & Sabbath & $3: 30-5: 00 p m$ & The Gift of Prophecy & Pastor N. Cleghorne \\
\hline 25 & Thursday & 7:00-9:00pm & Basic Computer & Staff \\
\hline 28 & Sunday & TBA & $\begin{array}{l}27 \text { Fundamental } \\
\text { Beliefs }\end{array}$ & Pastor B. Carter \\
\hline \multicolumn{5}{|l|}{ MAY } \\
\hline 2 & Thursday & $7: 00-9: 00 \mathrm{pm}$ & Basic Computer & Staff \\
\hline
\end{tabular}




\begin{tabular}{|c|c|c|c|c|}
\hline 9 & Thursday & 7:00-9:00pm & $\begin{array}{l}\text { Sermon Preparation } \\
\text { and Delivery }\end{array}$ & $\begin{array}{l}\text { Pastors: B. Carter \& } \\
\text { N. Cleghorne }\end{array}$ \\
\hline 11 & Sabbath & $3: 30-5: 00 \mathrm{pm}$ & $\begin{array}{l}\text { The Doctrine of } \\
\text { Health Reform }\end{array}$ & Pastor N. Cleghorne \\
\hline 16 & Thursday & 7:00-9:00pm & $\begin{array}{l}\text { Sermon Preparation } \\
\text { and Delivery }\end{array}$ & $\begin{array}{l}\text { Pastors: B. Carter \& } \\
\text { N. Cleghorne }\end{array}$ \\
\hline 18 & Sabbath & $3: 30-5: 00 p m$ & $\begin{array}{l}\text { Worship and the } \\
\text { Services of the } \\
\text { Church }\end{array}$ & Pastor B. Carter \\
\hline 19 & Sunday & TBA & $\begin{array}{l}27 \text { Fundamental } \\
\text { Beliefs }\end{array}$ & Pastor B. Carter \\
\hline 26 & Sunday & TBA & $\begin{array}{l}27 \text { Fundamental } \\
\text { Beliefs }\end{array}$ & Pastor B. Carter \\
\hline 30 & Thursday & 7:00-9:00pm & $\begin{array}{l}\text { Youth Ministry in the } \\
\text { Seventh-day } \\
\text { Adventist Church }\end{array}$ & Pastor N. Cleghorne \\
\hline \multicolumn{5}{|c|}{ JUNE } \\
\hline 1 & Sabbath & $3: 30-5: 00 p m$ & $\begin{array}{l}\text { Youth Ministry in the } \\
\text { Seventh-day } \\
\text { Adventist Church }\end{array}$ & Pastor N. Cleghorne \\
\hline 2 & Sunday & TBA & $\begin{array}{l}\text { The Doctrine of he } \\
\text { Sanctuary }\end{array}$ & Pastor B. Carter \\
\hline 6 & Thursday & 7:00-9:00pm & $\begin{array}{l}\text { Youth Ministry in the } \\
\text { Seventh-day } \\
\text { Adventist Church }\end{array}$ & Pastor N. Cleghorne \\
\hline 8 & Sabbath & $3: 30-5: 00 p m$ & Stewardship & Pastor N. Cleghorne \\
\hline 13 & Thursday & $7: 00-9: 00 \mathrm{pm}$ & OPEN & TBA \\
\hline 20 & Thursday & 7:00-9:00pm & OPEN & TBA \\
\hline 22 & Sabbath & TBA & Graduation & $\begin{array}{l}\text { Pastors: B. Carter \& } \\
\text { N. Cleghorne }\end{array}$ \\
\hline
\end{tabular}

TBA - To Be Announced

Please note: All persons participating in this program must endeavor to be at each seminar on time in order that the requirements for graduation might be fulfilled. 
YOUTH MINISTRY IN THE SEVENTH-DAY AD VENTIST CHURCH

Northeastern Conference of Seventh-day Adventists BROOKLYN TEMPLE SEVENTH-DAY ADVENTIST CHURCH Sabbath, June 1, 2003

All You Wanted to Know About Youth Ministry and Leadership in the Local Adventist Youth Society

Pastor Newton U. Cleghorne,

Youth Ministries Director

Northeastern Conference of Seventh-day Adventists 


\section{WHO IS AN ADVENTIST YOUTH SOCIETY (AYS) LEADER?}

1. The Adventist Youth Leader is the elected person through the Nominating Committee or the Church Board whose duty it is to ensure that the life of every youth in the local church reaches its full potential-mentally, physically, socially and spiritually. Luke 2:52.

2. Serves as Chairperson of the Youth Executive Council.

3. Recommend additional persons to serve in the AY Society, when necessary.

4. Serves as a member of the Church Board representing the interests of the Youth.

5. Keeps the Elder responsible to the Youth Society, the Pastor and the Church Board informed of all major plans and projects being undertaken by the AY Society, and seeks appropriate approval and support.

6. Keeps in touch on a regular basis with the Conference Youth Ministries Personnel, to discuss plans, problems, and needs and arranges for the Youth Director through the Federation President to visit the Society when appropriate.

7. Seeks to understand and minister to the total needs of the youth of his or her church. Through personal contact the leader will become acquainted with the successes, hopes, fears and problems of youth associated with the local church. 


\section{WHAT QUALIFIES SOMEONE TO BE AN AYS LEADER?}

1. Has a personal relationship with Jesus Christ.

2. Loves young people unconditionally.

3. Has the ability to cast a vision and see it come to fruition.

4. Starts things and makes them succeed

5. Finds solutions to problems/challenges

6. Directs and uses all the talents and resources at his/her disposal to achieve the goals set.

7. Knows how to delegate responsibility and incorporate others in decision-making.

8. Has a pleasant personality and makes friends easily.

WHAT ARE SOME LEADERSHIP STYLES AND PERSONALITIES?

\section{LEADERSHIP STYLES}

AUTHORITARIAN (autocratic and dictatorial)

DEMOCRATIC/PARTICIPATIVE

LAISSEZ-FAIRE (permissive), SITUATIONAL LEADERSHIP

LEADERSHIP PERSONALITIES

SANGUINE

CHOLERIC

PHLEGMATIC

MELANCHOLY 


\section{WHAT IS AN AY SOCIETY?}

The Adventist Youth Society is a department of the Seventh-day Adventist Church through which the church works for and through her youth. It is the action and fellowship organization for Senior Youth and Young Adults in the local Church. Under the leadership of an elected Youth Leader, Young people are to work together in the development of a strong youth ministry, which includes the spiritual, mental, physical and social development for each individual. In the book, Gospel Workers, page 67, Ellen G. White asserts: "In order that the work may go forward in all its branches, God calls for youthful vigor, zeal, and courage. He has chosen the youth to aid in the advancement of His cause. To plan with clear mind and execute with courageous hand, demands fresh, uncrippled energies. Young men and women are invited to give God the strength of their youth, that through the exercise of their powers, through keen thought and vigorous action, they may bring glory to Him and salvation to their fellow-men."

While there is to be an active AYS in every church, it is important that the youth program not be isolated from the rest of the church. In addition to their participation in the youth organization, the young people should be integrated into responsible leadership and involvement in the entire church program. There should be youthful representation in all offices, committees and areas of leadership in each church. 


\section{WHAT ARE THE OBJECTIVES OF THE AY SOCIETY?}

TO: 1 . Train the youth to work for other youth 2 . Recruit the youth to help their church and "those who profess to be Sabbath keepers" and 3. Work for "those who are not of our faith." Signs of the Times, May 29, 1893. In summary, "To save from sin and guide into Service."

\section{HOW DOES ONE BECOME A MEMBER OF THE AY SOCIETY?}

There are three categories of membership in the Adventist Youth Society:

1. Regular Members. These are baptized young people, who are members of the Seventhday Adventist Church up to the age of thirty-five and are in regular standing. They subscribe to the Aim, Motto, Law, Pledge, AY Legion of Honor and Song, the objectives of the society, desire to engage in active service for Christ and in the salvation of their peers and other youth.

2. Associate Members: These are young people who are not yet members of the Seventhday Adventist Church, but who have Christian ideals and desire to be associated with the young people of the church in missionary work. They may not hold office, but they should be cordially received into society work and into its bands, and be encouraged to become regular members as soon as possible.

3. Honorary Members: These are adult members of the church, above the age of thirtyfive who support the youth and attend the AYS meetings and participate on a regular basis. Their membership is not included in the secretary's report, and they report their 
outreach or missionary work in the regular way through the Personal Ministries Department.

\section{SOME IMPERATIVES OR MUSTS OF AY LEADERSHIP}

\section{HAVE A CLEAR UNDERSTANDING OF THE THEOLOGY OF YOUTH MINISTRY.}

Any theology of youth ministry that is not built on a solid biblical foundation will just be driven by sociological, psychological and political factors that are current at the time. In other words, totally humanistic. Our theology for youth Ministry is found in the life and ministry of Jesus.. He is our model of Incarnational ministry.

Ellen G. White was very familiar with Incarnational Ministry. In her book, Gospel Workers, pp, 207-212, she states, "Why should not labor for the youth in our borders be regarded as missionary work of the highest kind? It requires the most delicate tact, the most watchful consideration, the most earnest prayer for heavenly wisdom. The youth are the objects of Satan's special attacks; but kindness, courtesy, and sympathy which flows from a heart filled with love for Jesus, will gain their confidence, and save them from many a snare of the enemy... There must be more study given to the problem of how to deal with the youth, more earnest prayer for the wisdom that is needed in dealing with minds...We should seek to enter into the feelings of the youth, sympathizing with them in their joys and sorrows, their conflicts and victories...We must meet them where they are if we would keep them...let us remember the claim of God upon us to make the path to heaven bright and attractive." 
Her best description of how to do Incarnational ministry is the statement in Ministry of Healing, 143: "Christ's Method alone will give true success in reaching the people. The Savior mingled with men as one who desired their good. He showed His sympathy for them, ministered to their needs, and won their confidence. Then He bade them, "Follow Me." In short, herein lie the five secrets to a successful Youth Ministry. Jesus Socialized, Sympathized, Served, Secured and Saved. If you would have a successful youth ministry in your church, you must go and do likewise.

Youth ministry built on this model seeks to meet young people where they are, and to offer them pastoral care not only as spiritual guides, but also as counselors and friends, fellow pilgrims on a similar spiritual journey. With Jesus as our model we are called to a ministry, personal and relational ministry that will involve a good deal of one to one time. Incarnational ministry will involve empowering and releasing young people to become a part of the ministry. In this there is no place for the power hungry, because it is a call to selfless service. Matthew 20:26-28, ....but whosoever desires to become great among you, let him be your servant. And whoever desires to be first among you, let him be your slave-just as the Son of Man did not come to be served, but to serve, and to give His life a ransom for many. (NKJV).

\section{DEVELOP A CLEAR PERSONAL PHILOSOPHY OF YOUTH MINISTRY}

For one to construct a philosophy of Youth Ministry, it is imperative to have a sound Theology of Youth Ministry. If someone were to ask you what is your philosophy of youth ministry? Do you know why you do what you do? How would you answer? Dr. Bertram Melbourne, former Youth and Education Director of the West Jamaica 
Conference of Seventh-day Adventist, in a presentation on Youth Ministries said, "Don't undersell the Advent message in your thinking. Don't depreciate it by your ignorance. Know why you are what you are and let the world know it." It is therefore important that each AY Leader be able to give a clear definition, born out of an experience, on their philosophy of Youth ministry.

Here are some definitions for Youth Ministry inclusive of a philosophy of youth ministry:

1. Youth ministry includes an intentional focusing on God's saving acts in history in such a way as to meet the needs of young people at their stage of development and draws them into a saving relationship with God through Jesus Christ.

2. Dr. Duffy Robins in his book, Youth Ministry: Nuts and Bolts writes: "Youth ministry isn't a matter of budgeting, publicizing and organizing. It is a matter of loving teenagers [and all youth], spending time with them, and helping them hear and understand the gospel of Christ."

3. Youth ministry is ministering one to one, reaching out to non-participants so they become involved. It takes place whenever you are with young people, developing leadership in them and turning them from being spectators into participants.

4. Youth ministry is building relationships with young people in order to lead them to a lasting relationship with and a commitment to God.

5. Dr. Tony Campolo in his book, Ideas for Social Change admits: "Young people are not going to be attracted to a church that tries to entertain them, but they will be attracted to a church that calls them in a ministry to others... Young people want a church that will provide them with concrete ways to become agents of God's revolution." 
6. Dr. A. Barry Gane in his book, Building Youth Ministry: A Foundational Guide remarks, "Youth ministry is a ministry of emotional touching. Such an idea demands person-centered teaching, need-meeting programming and spirit- [soul] satisfying relationships."

\section{KNOW THE HISTORY AND DEVELOPMENT OF YOUTH MINISTRY IN THE SEVENTH-DAY ADVENTIST CHURCH WORLDWIDE AND IN YOUR OWN CHURCH.}

The year was 1879.. The two young men, Harry Fenner (17) and Luther Warren (14) were walking down the old country road of Hazelton, Michigan. They were impressed that youth should be more involved in the sharing of the gospel. They decided to pray about the matter, so after scaling the rail fences along the road, they found a secluded spot underneath some trees where they knelt down and prayed that God would open up a way to begin a ministry for youth. They brought the matter to the church board and they voted to begin the first Young People's. Society at the Hazelton (now Juddville Center) Seventh-day Adventist Church, Michigan.

They were only nine charter members-all boys, at the first meeting. They voted a President and a Secretary-treasurer, reported the missionary work for the previous week, drew up and signed a temperance pledge and took up an offering to purchase literature for missionary distribution and for other expenses.

After a few weeks, the girls became a part of the Young People's Society, thus making it all-inclusive. Twelve years later, in 1891, Meade MacGuire formed a similar group in the church at Antigo, Wisconsin. When he made the proposal to the church, it was met with grave opposition. However, the elder of the church placed his hand on his shoulder 
and said, "My boy, you go right ahead. You may have the church for your meeting, and I will stand by you."

In 1892, led by the Spirit, Ellen White wrote her first testimony in favor of mobilizing the denomination's "army of Youth" into active service for God. Writing from Melbourne, Australia, December 19, 1892 she said, "We have an army of youth today who can do much if they are properly directed and encouraged...Let all be so trained that they may rightly represent the truth, giving the reason of the hope that is within them, and honoring God in any branch of the work where they are qualified to labor."

After Ellen White's counsels were taken seriously, the first Young People's Society, outside North America was formed, at the Adelaide Seventh-day Adventist Church in Adelaide, Australia by the President of the Australasian Conference, Elder A.G. Daniells.

In Mount Vernon, Ohio, in April, 1899, the first conference to form a general organization for Adventist Youth was convened and at the camp meeting held in August of that year, a state-wide organization know as Christian Volunteers was voted, which was assimilated by the Missionary Volunteer Department upon its organization in 1907. In 1901, the youth of Sigourney, Iowa were organized and later, the first step was taken toward the development of the work for youth on a worldwide basis. At the General Conference Council at Gland, Switzerland in the Spring of 1907, the Youth Department of Missionary Volunteers (MV) was voted. Elder Milton E. Kern became the first Youth Director.

In 1972, the name was changed from the Missionary Volunteer Department (MV) to the Youth Department of Missionary Volunteers and Conference MV Secretaries were given the title, Youth Directors. However, due to the association of the name Missionary 
Volunteers (MV) to militant and subversive groups in some parts of the world, the name was changed to Adventist Youth Department (AY) in 1978. The meetings in the local churches are called Adventist Youth Society (AYS) meetings.

From a small group of nine boys in Hazelton, Michigan this Adventist army of Youth has grown to nearly half of the total membership of the Seventh-day Adventist Church. It was the remnant prophetess, Ellen G. Harmon-White who wrote the profound statement, "We have nothing to fear for the future, except as we shall forget the way the Lord has led us and His teaching in our past history." Life Sketches, 196.

4. KNOW AND UNDERSTAND THE AY AFFIRMATION AND BE ABLE TO QUOTE IT FROM MEMORY (SEE THE CURRENT CHURCH MANUAL, 16 $^{\mathrm{TH}}$ EDITION, PAGES 102, 106 AND 127)

The AIM:The Advent Message to all the world in my Generation (formerly this generation)

The MOTTO: The Love of Christ constrains me. (formerly constrains us).

THE ADVENTIST SENIOR YOUTH-YOUNG ADULT PLEDGE:

Loving the Lord Jesus, I promise to take an active part in the work of the Adventist

Youth Society, doing what I can to help others and to finish the work of the gospel in all the world. (Formerly "in the Youth Ministry of our church") Right hand over your heart THE ADVENTIST JUNIOR YOUTH (AJY) PLEDGE: By the grace of God, I will be pure and kind and true, I will keep the Adventist Junior Youth Law, I will be a servant of God and a friend to man.

THE ADVENTIST JUNIOR YOUTH LAW

The Adventist Junior Youth Law is for me to-

Keep the Morning Watch,

Do my honest part, 
Care for my body,

Keep a level eye,

Be courteous and obedient,

Walk softly in the sanctuary,

Keep a song in my heart,

Go on God's errands.

The Aim and Motto are the same as for the Senior Youth and Young Adults.

\section{THE AY LEGION OF HONOR}

"I volunteer now to join the AY LEGION OF HONOR and by the grace and power of God I will:

HONOR CHRIST in that which I choose to BEHOLD.

HONOR CHRIST in that which I choose to LISTEN.

HONOR CHRIST in the choice of PLACES to which I GO.

HONOR CHRIST in the choice of ASSOCIATES.

HONOR CHRIST in that which I choose to SPEAK.

HONOR CHRIST in the care I give my BODY TEMPLE."

The MV (AY) Legion of Honor came as a result of much prayer on the part of the MV Advisory Committee, which had met in 1953 in their annual council. They framed a code to which Adventist youth might voluntarily subscribe, and thus pledge to answer Christ's call and honor Him in the lofty standards of this covenant. It was inaugurated at a time when Adventist Youth leaders sensed anew the value of this statement from the pen of Ellen G. White, Messages To Young People, 270: 
"Say firmly: 'I will not spend precious moments in reading that which will be of no profit to me, and which only unfits me to be of service to others. I will devote my time and my thoughts to acquiring a fitness for God's service. I will close my eyes to frivolous and sinful things. My ears are the Lord's, and I will not listen to the subtle reasoning of the enemy. My voice shall not in any way be subject to a will that is not under the influence of the Spirit of God. My body is the temple of the Holy Spirit, and every power of my being shall be consecrated to worthy pursuits."

The AY Song: Adventist youth are we from every land and sea. Together we pray and work and play in happy harmony. We have a faith to share with others everywhere, a message of love from God above, to show that world we care. Adventist Youth, Adventist Youth, Adventist Youth.

\section{KNOW THE ORGANIZATIONAL STRUCTURE OF THE AY SOCIETY}

\begin{tabular}{c} 
GC Youth Advisory Council \\
\hline Division Youth Advisory Council \\
\hline Union Youth Advisory Council \\
\hline Conference Youth Advisory Council \\
\hline Area AY Federation \\
\hline \\
Local Church Board \\
\hline Adventist Youth Ministries Committee \\
\hline AY Society Committee
\end{tabular}

The AY Ministries Committee is the umbrella organization in the local church responsible for the general planning of the youth ministry program. The AYS Leader is the Chairperson of this committee. This committee handles every aspect of the life of the youth. The composition of it therefore encompasses every department that affects the 
life of young people. It identifies, and constantly assesses the needs of the youth in the local church. It recommends strategies, programs and support mechanisms to meet the discovered needs. It coordinates all youth activities in the local church, in conjunction with the Church Board, and supports and promotes local Conference Youth Activities. It evaluates youth activities and sees that they are meeting the needs they were designed to cater for and recommend appropriate changes where necessary.

The committee includes: 1 . The AY leader (elected), 2. Associate AY Leaders (elected), 3. AY Sponsor (elected), 4. Secretary-Treasurer (elected), 5. Assistant Secretary-Treasurer (elected), 6. Chorister (Praise Team Leader, elected), 7. Pianist and or Organist (elected), 8. Adventurer Director (added, elected), 9. Personal Ministries Leader (added, elected), 10. Elder Assigned to the AY Department (elected, added), 11. Master Guide Club Director (elected/appointed/optional), 12. Adventist Junior Youth Society Leader (elected), 13. Education Secretary (added, elected), 14. Sabbath School Superintendent (added, elected), 15. Youth Sabbath School Division Leader 16. Health Ministries Leader (elected, added) 17. Church School Principal (voted by the School board and ratified by the Church Board, added). 18. The Church Pastor is an ex-officio member of all committees.

This committee should meet at least once every quarter or more often as needed, to ascertain that Youth ministries is being done in every aspect of church life and that the evaluation instruments are being used to determine if needs are being met. 
The Adventist Youth Society Committee

The Adventist Youth Society Committee is responsible for Senior Youth and Young Adult activities of the local church and works in coordination with other youth entities through the Adventist Youth Ministries Committee. Where there is no Pathfinder or Adventurer program, the AYS will include these younger members in an Adventist Junior Youth Society (AJY). The success of the AYS is largely measured by the kind of Leader it has. When leaders are wholly dedicated to Jesus and to the saving of lost souls and the training of the youth to become effective leaders the effect will be experienced in the whole church.

The members of the AYS Committee are 1. AY Leader (elected), 2. Associate Leader/s (elected), 3. Secretary-Treasurer (elected), 4. Assistant Secretary-Treasurer (elected), 5. Chorister (Praise Team Leader), 6. Pianist and /organist (elected), 7. Sponsor (elected) and 8. Elder responsible for Youth Ministries (elected), 9. Fellowship/Social Leader (appointed), 10. Devotional/Discipling/Outreach Leader (appointed), 11. Librarian or Educational Leader (appointed), 12. Publicity/Communications Leader (appointed), 13. Band Leaders (appointed), 14. Adventurer Leader, 15. Pathfinder Leader and 16. Personal Ministries Leader.

The AYS Committee should meet at least once every month for planning and evaluation and meet once per week for prayer preceding each meeting and a general overview of the meeting about to be conducted. 


\section{SAMPLE OUTLINE OF AN AYS PROGRAM}

PRAISE SERVICE

Opening Remarks

Opening Song

Scripture Lesson (Focusing on Theme of Program)

AYS Affirmation: Aim, Motto, AJY Law, AJY Pledge, AY Pledge, AY Legion of Honor, AY Song (See Pages)

Opening Prayer (Traditional and Untraditional)

WELCOME

Minutes of the Past AY Meeting

Roll Call

Devotion: Morning Watch, Devotional Comments

Bands Meet and Take Records of Missionary Activities

OFFERING

Special Music

Program for the evening

Objectives highlighted

Evaluation (Did we meet our objectives?)

Special Music or congregational Hymn

VESPERS (Continuing the Theme of AY Program) without obvious break.

Appeal for those who desire to live out the spiritual values in AY Program

Closing Hymn (optional

Closing Prayer 


\section{KNOW HOW TO EFFECTIVELY FUNCTION AS CHAIRPERSON OF THE ADVENTIST YOUTH EXECUTIVE COUNCIL.}

To be an effective Chairperson:

1. Start your meeting on time

2. Know the basic parliamentary procedures for the conduct of a meeting.

3. If possible, send the minutes of the previous meeting and the agenda of the current meeting to acquaint members beforehand. Request of members to raise any questions on the agenda before the meeting.

4. Determine the feeling and tone of the meeting, summing up, getting agreement (by voting) and coming to conclusions without dominating.

5. Ensure that accurate minutes are recorded in respect to recommendations and decisions.

6. Assign work, check reports and encourage all members to contribute to the success of the meeting.

7. Prevent anyone from monopolizing the meeting, avoiding arguments, discouraging interruptions, and concluding with clearly understood decisions.

8. Begin and end with prayer

9. Always bring a devotional thought that can help steer the agenda in the direction that you want it to go.

10. Chairmanship is one of the tools of leadership. Practice constantly so that the skill will be developed to a competent level. 


\section{OUTLINE OF AN ADVENTIST YOUTH MINISTRIES COMMITTEE OR AYS COMMITTEE MEETING}

CALL THE MEETING TO ORDER (Use a gavel or similar instrument) DEVOTION

PRAYER (Individual or Season)

APPRECIATION FOR THOSE IN ATTENDANCE

DETERMINE THE QUORUM (If one is stipulated)

MINUTES

Correction to the Minutes (additions or deletions)

Adoption of the Minutes by vote

Matters Arising

\section{NEW BUSINESS}

1.

2.

3.

4.

5. AOB (Any Other Business)

6. NEXT MEETING-TIME AND PLACE

7. ADJOURNMENT AND PRAYER 


\section{KNOW HOW TO PLAN A SUCCESSFUL YEAR OF YOUTH ACTIVITIES}

1. In order to plan effectively the leader must know the Conference calendar of events for each year.

2. Merge that calendar with the calendar of the local church

3. Know all the major holidays and events of each year and incorporate them in the general schedule.

4. Know all the birthdays and anniversaries of each member of the society

5. Have your ears on the ground for any changes that may occur.

6. Follow the steps below:

a. Bring your Executive for a Visioning process and brainstorming session to determine the pressing and felt needs of your society and where you need to take it.

b. Categorize and assess your needs under specific headings from the list of ideas brought forth.

c. Develop strategies, goals or objectives to meet those needs. When setting goals it is wise to follow the SMART approach. Specific, Measurable, Attainable, Realistic and Tangible.

d. Execute the strategies developed by involving as many in the organization as possible.

e. Evaluate the effectiveness of the plans and programs implemented.

f. BEGIN THE PROCESS ALL OVER AGAIN. 


\section{DEVELOP A MISSION STATEMENT THAT CLEARLY DEFINES THE REASON FOR THE EXISTENCE OF YOUR AY SOCIETY}

A mission or purpose statement is a general statement reflecting the direction you want your SOCIETY to go. It is important to write it down and make it public, so your organization knows it and is influenced by it. It is the raison d'etre of the organizationyour reason for being and existence. It answers to the question, "Why do we exist as a society?"

Examples: We exist to create an accepting and caring environment where young

$$
\text { people can find positive fellowship." }
$$

"The primary focus of Youth ministry is the salvation of youth

through Jesus Christ. We understand youth ministry to be the work of the church that is conducted for, with, and by young people." 


\section{PREPARE A YEARLY BUDGET REFLECTING YOUR POSSIBLE INCOME AND EXPENSES}

\begin{tabular}{|l|r|}
\hline INCOME & COST IN DOLLARS \\
\hline CHURCH ALLOCATION & $5,000.00$ \\
\hline SPECIAL DONATIONS & $2,000.00$ \\
\hline OFFERINGS & $2,500.00$ \\
\hline TOTAL INCOME & $\underline{\mathbf{9 9 5 0 0 . 0 0}}$ \\
\hline
\end{tabular}

\begin{tabular}{|l|r|}
\hline EXPENDITURES & COST IN DOLLARS \\
\hline AY WORKSHOP & $1,000.00$ \\
\hline WEBSITE & 500.00 \\
\hline BOOKS & 500.00 \\
\hline SOCIALS & 800.00 \\
\hline YOUNG PREACHERS' INSTITUTE & 400.00 \\
\hline NAD COMBINED Y M C & $1,000.00$ \\
\hline FEDERATION DUES & 250.00 \\
\hline PROGRAM MATERIALS & 700.00 \\
\hline AY WEEK OF PRAYER & 250.00 \\
\hline HONORARIA FOR GUEST SPEAKERS & 700.00 \\
\hline GIFTS TO GRADUATES & $1,000.00$ \\
\hline PRAYER BREAKFAST & 500.00 \\
\hline LOCK-INS & 300.00 \\
\hline AWARDS BANQUET & $1,000.00$ \\
\hline OUTREACH PROJECTS & 300.00 \\
\hline MISCELLANEOUS & 300.00 \\
\hline TOTAL & $\mathbf{9 9 . 5 0 0 . 0 0}$ \\
\hline
\end{tabular}

\section{BE ON THE CUTTING EDGE OF CURRENT TECHNOLOGY}

1. Own a Computer (preferably a laptop)

2. Know how to use a computer and any special Word Processing program

3. Have an E-mail address and know the addresses of all your staff and use the information to communicate constantly with them.

4. Know how to use Power Point to make presentations 
5. Know how to use a scanner with your computer.

6. Know how to use or own a Palm Pilot

7. Your society should have a Web site.

8. Your society should have a digital camera for still photographs and a camcorder for moving pictures.

9. Know how to surf the web for all the positive information you need to help yourself and your Society.

10. Know how to burn CD's (optional)

\section{KNOW WHERE TO FIND RESOURCES TO MAKE A SUCCESSFUL AY SOCIETY}

1. Non-SDA Web site: http://www.YouthSpecialties.com

2. The latest books on Youth Ministries—http://www.Zondervan.com

3. SDA Websites: http://www.tagnet.org/dvm/wildweb.html. This will link you to a world of sites. adventistyouthministries.org (will be up soon). Youth@gc.adventist.org

4. SDA Youth Organizations: NAD Menu

12. DEVELOP AND EMPOWER POTENTIAL LEADERS AROUND HIM/HER

1. Trains

2. Mentors: I do, You watch; I do, You help; You do, I help; You do, I watch.

3. Positions

4. Liberates 


\section{EVALUATE THE PERFORMANCE OF THE AY SOCIETY IN ALL AREAS ON A REGULAR BASIS}

Why do we need an evaluation? Evaluation identifies the successes and failures of an organization and is a litmus test for determining its health.

Ask yourself these questions before and after your program. You'll increase the chances Of meeting needs and helping your youth grow spiritually:

- Do your programs meet needs?

- Are they Christ-centered or entertainment-centered?

- Do they reflect the mission and vision of the Society?

- Are they intellectually challenging?

- Are they relational in their appeal?

- Do they include everyone?

- Are they sensitive to parent needs and ethnic and gender diversity?

Ask your youth these questions after every program

1. How would you rate this program (on a scale of 1-10 or Excellent, Good, OK, Fair or Poor)?

2. What did you like best?

3. What did you like least?

4. What can we do to improve it the next time? 
14. UNDERSTAND THE YOUTH CULTURE IN ORDER TO EFFECTIVELY MINISTER TO THE YOUTH

Culture is the sum total of ways of living, built by a group of human beings and transmitted from one generation to another.
a. Music
b. Recreation
c. Morality
d. Friendship and Peer Pressure
e. Food
f. Style, Fashion and Dress
g. Sports and Competition
h. Drugs
i. Entertainment-TV, Video, Technological Gadgets

\section{KNOW THE DIVISIONS OF YOUTH MINISTRIES AND THEIR LINKS OR TRIBUTARIES}

\begin{tabular}{|l|l|l|}
\hline Division & Name & Ages \\
\hline Pre-Adventurers & Eager Beavers & $4-5$ \\
\hline $\begin{array}{l}\text { Pre-Adventist Junior } \\
\text { Youth }\end{array}$ & Adventurers & $6-9$ \\
\hline Adventist Junior Youth & $\begin{array}{c}\text { Pathfinders and Regular } \\
\text { AJY }\end{array}$ & $10-15$ \\
\hline Adventist Youth & Senior & $16-22$ \\
\hline Adventist Youth & Young Adult & $23-35$ \\
\hline
\end{tabular}

***** Refer to the links and tributaries in the Handout on Responsibilities of the Youth Director and Associate Youth Director. 


\section{ATTEND AT LEAST TWO YOUTH MINISTRIES CONVENTIONS FOR THE CALENDER YEAR}

The personal and professional growth and development of the Adventist Youth Leader is not an option, it is a necessity. Any AY Leader functioning within this $21^{\text {st }}$ Century must be constantly on the cutting edge of new approaches, paradigm shifts and programs that will help to package the delivery of Youth ministry in a more colorful and appetizing and needs-meeting way. Of the two conventions/workshops one should be an SDA and the other Non-SDA.

17. BE FAMILIAR WITH THE CONSTITUTION AND BYLAWS OF THE ADVENTIST YOUTH FEDERATION

Handout Available.

When these are followed prayerfully, carefully and intentionally, we will produce a cadre of the best Adventist Youth Leaders around the world. Now it's in your hands to become the best. Do not settle for less. 


\section{REFERENCES}

Benson, Warren S. and Mark H. Senter, III. The Complete Book of Youth Ministry. Chicago, IL: Moody Press, 1978.

Center for Youth Evangelism, 7 Principles of Youth Ministry Excellence. Lincoln, NE: Advent Source, 1999.

Fields, Doug. Purpose-Driven Youth Ministry. Grand Rapids, Michigan: Zondervan Zondervan Publishing House, 1998.

Gane, A. Barry. Building Youth Ministry: A Foundational Guide. Riverside, California: La Sierra University Press, 1997.

General Conference of Seventh-day Adventist, The Seventh-day Adventist Church Manual, Revised 2000, $16^{\text {th }}$ Edition. Hagerstown, MD, 2000.

. Youth Ministry Handbook and Leadership Training Manual. Hagerstown, $\mathrm{MD}, 2000$.

. Youth Ministry Training Course Manual. Hagerstown, MD, 2000.

Richards, Lawrence O. Youth Ministry: Its Renewal in the Local Church, Revised. Grand Rapids, MI: Zondervan Publishing House, 1985.

Ward, Peter. God At the Mall. Peabody, Massachusetts: Hendrickson Publishers, Inc., 1999. 


\section{ADDITIONAL RESOURCE}

Clarke, Chap. The Youth Worker's Handbook to Family Ministry: Grand Rapids, Michigan: Zondervan Publishing House, 1997.

Edmond, Dana C. Do It Right: Love Sex and Relationships God's Way. Hagerstown, MD: Review and Herald Publishing Association, 2001.

General Conference of Seventh-day Adventists Ministerial \& Youth Depts. Pastor's \& Elder's Handbook for Youth Ministry. Silver Springs, MD: General Conference of Seventh-day Adventists, 2002.

. The General Conference Rules of Order. Hagerstown, MD: Review \& Herald Publishing Association, 2000.

. The Seventh-day Adventist Church Manual. Hagerstown, MD: Review \& Herald

Publishing Association, 2000.

Norman, Bruce. Bridging the Gap. Silver Springs, Maryland: North American Division Church Resources Consortium, 2003.

Pacific Union Conference, Church Ministries Department. Taking the Lead: Youth Apprenticeship Program. Westlake Village, California: Pacific Union Conference, 1990.

Sinsabaugh, Ginger. Help! I'm an Urban Youth Worker!: A Survival Guide to Ministry in the Big City. Grand Rapids, Michigan: Zondervan Publishing House, 2001.

Spivey, Loretta. Straight Talk About Love and Relationships.

Williams, Richard. Torches: On the Road of Passage. Rochester, New York: Hema Publishing, 2001. 


\section{NORTHEASTERN CONJERENCE \\ EEADERS-IN-TRAININGG PROGR.A.M: EMPOWER.MENT}

BRDOKLYN TEMPLE SDA CHURCH

BROOKLYN, NY

APRIL 11, 18, 2002

\section{EFFECTIVE MEETING AND \\ PARLIAMENTARY PRDCEDURES}

Presented by

Pastax e Newtan U. Qleghone

South Dixectox, ONoxtheastern Confexence of Peventh-day eddrentists 


\section{Definitions:}

Meeting:- A meeting is a gathering of three or more people sharing common objectives. A meeting officially begins when the quorum is present and the presiding officer/chairperson calls the group to order using a gavel/or his/her knuckles to tap against the table, desk or podium and calls the meeting to order. This meeting of the is now called to order on this the. day of in the year of our Lord at.

Quorum:- A quorum is the minimum number of members who must be present in order for the organization to transact business. The bylaws of that organization describes that number. Effective:- excellent, to the point, beneficial, facilitates in the accomplishment of goals.

Procedures:- Approaches, ways and means, guidelines.

Kinds of Meetings :- professional, civic, service club or religious.

\section{There are two major classification of Meetings:-}

Information meetings and Decision-making meetings. Information Meetings are for the giving of advice or update and to sell an idea or proposal. Decision-making meetings are for goal-setting and problem-solving. 


\section{Differences in these two types of meetings:}

\begin{tabular}{|l|l|l|}
\hline Elements & Information Meeting & Decision-making Meeting \\
\hline Number of attendees & Any number & $\begin{array}{l}\text { Small size, preferably not more } \\
\text { than 12 }\end{array}$ \\
\hline Who should attend & Those who need to know & $\begin{array}{l}\text { Those responsible and who can } \\
\text { continue the process }\end{array}$ \\
\hline Communication Process & $\begin{array}{l}\text { One way from leader to } \\
\text { participants with } \\
\text { opportunities for } \\
\text { questions }\end{array}$ & $\begin{array}{l}\text { Interactive discussion among all } \\
\text { attending }\end{array}$ \\
\hline Meeting Room set-up & $\begin{array}{l}\text { Participants facing front } \\
\text { of room, classroom style }\end{array}$ & $\begin{array}{l}\text { Participants facing each other, } \\
\text { conference style }\end{array}$ \\
\hline $\begin{array}{l}\text { Most effective style of } \\
\text { leadership }\end{array}$ & $\begin{array}{l}\text { Authoritative } \\
\text { Emphasis should be on }\end{array}$ & Participative \\
\hline $\begin{array}{l}\text { Key to Success } \\
\text { Content }\end{array}$ & $\begin{array}{l}\text { Planning and preparing } \\
\text { of information to be } \\
\text { presented }\end{array}$ & $\begin{array}{l}\text { Meeting climate that supports } \\
\text { open and free expression }\end{array}$ \\
\hline
\end{tabular}

The BIG question :- When is a meeting effective? A meeting is effective when it achieves its objectives in a minimum amount of time to the satisfaction of the participants. For any meeting to be successful, effective and meaningful, the chairperson must be fully prepared for the task. 


\section{Duties of the Chairperson (Appendix)}

To be an effective chairperson, one must be prepared to do the following:

\section{After the quorum is present}

1. Start on time

2. Begin and end with prayer

3. State your meeting objective/s clearly

4. Always have a thought that will steer the agenda in the direction that you want it to go.

5. Know the basic parliamentary procedures for the conduct of a meeting.

6. Send the minutes of the previous meeting and the agenda of the current meeting ahead of time to acquaint members beforehand. Request members to raise any questions on agenda before the meeting begins.

7. Determine the feeling and tone of the meeting, summing up and arriving at decisions without dominating.

8. Ensure that accurate minutes are recorded in respect to recommendations and decisions.

9. Assign work, check reports and encourage all members to contribute to the success of the meeting.

10. Do not allow anyone to monopolize the meeting, initiate heated arguments, make unnecessary interruptions.

11. Conclude with clearly understood decisions.

12. Announce the time and place of the next meeting. 
NB: Chairpersonship is one of the effective tools of leadership. Practice constantly so that the skill will be developed to a competent level.

\section{Evaluate your Oleeting}

\section{Yes No}

1. An agenda is prepared prior to the meeting.

2. Meeting participants have an opportunity to contribute to the agenda.

3. Meeting facilities are comfortable and adequate for the number of participants.

4. The meeting begins on time

5. The meeting has a scheduled ending time.

6. Advance notice of meeting time and place is provided.

7. The use of time is monitored throughout the meeting.

8. Everyone has an opportunity to present his or her own point of view.

9. Participants listen attentively to each other.

10. There are periodic summaries as the meeting progresses

11. No one tends to dominate the conversation.

12. Everyone has a voice in decisions made at the meeting.

13. The meeting typically ends with a summary of accomplishments

14. The meeting is periodically evaluated by participants.

15. People can be depended upon to carry out actions agreed to during the meeting.

16. A memorandum of discussion or minutes is available to each participant following the meeting. 
17. The meeting leader follows up with participants on actions agreed to during the meeting.

18. The appropriate and necessary people can be counted on to attend each meeting.

19. The decision-making process used is appropriate for the size of the group.

20. When used, audio-visual equipment is in good working condition and does not detract from the meeting.

The number of statements checked _ $\times 5=$ (Meeting Score)

A score of 80 and higher indicates high quality meetings. A score of 60 or less indicates room for improvement.

\section{The Essential Elements of an effective Nleeting}

\section{Planning the Meeting}

When planning a meeting, you must first decide whether or not one is required. All too often holding a meeting is a foregone conclusion when it should be a carefully considered decision. Every meeting needs to have objectives. They should be clearly presented in the chairperson's opening statement. This simple procedure establishes the reason for the meeting. With an objective in mind, all discussions and energy can be directed toward it.

Objectives are to inform, sell, decide, determine or to challenge. They must reflect the SMART approach- Specific, Measurable, Attainable, Realistic and Tangible. 


\section{Develop an agenda}

This is a must. It should be prepared in advance and given to participants before the meeting. It will serve as a road map to keep discussions focused. When distributed before the meeting, an agenda encourages advance preparation.

If the organization's bylaws do not prescribe an order of business, there is a series of steps that are commonly accepted:

1. Call the meeting to order at the appointed time with a quorum present

2. Read, correct and approve the minutes of the previous meeting

3. Hear reports of officers

4. Hear reports of boards

5. Hear reports of standing committees

6. Heat reports of special committees

7. Consider unfinished business

8. Consider new business

9. Hear announcements and requests that require no formal action (FYI)

10. Assign tasks to members with a follow up procedure

11. Set a time, date and place for the next meeting

12. Adjourn. 


\section{Here is a simplified version of an Agenda:}

Call to order

Devotion

Objectives for the meeting and time commitment

Minutes:

Corrections (additions or deletions)

Adoption of minutes

Matters Arising from

Unfinished Business of last meeting

\section{$\underline{\text { New Business }}$}

1.

2.

3.

4. Any other business (AOB)

5. FYI

6. Next Meeting (Date, Time and Place)

7. Adjournment \& Prayer 
3. Determine the location of your meeting and Set up in advance of meeting

Number of chairs and tables

Formation of chairs as they relate to the kind of meeting

Handouts in packages

Lighting

Audio Visual equipment

Refreshments

Schedule breaks for meetings longer than an hour and a half

\section{Take charge and conduct meeting with efficiency to the end}

\section{Evaluate the meeting by asking the following questions:}

A. How would you rate this meeting (on a scale of 1-10 or Excellent, Good, OK, fair or Poor)?

B. What did you like best?

C. What did you like least?

B. Were the objective/s met?

E. What suggestions for improvement would you recommend for the next meeting? 


\section{TERMS TO REMEMBER}

Parliamentary Procedure is a way to conduct a meeting in an orderly manner.

Parliamentary procedure, also known as rules of order helps the presiding officer keep order during a meeting as well as guide participants in transacting business. The procedure is called parliamentary because it comes from the rules and customs of the British Parliament. By the end of the 1600 's the broad principles had become well established. As actual procedures developed, they became the basis for deciding later questions of parliamentary law. In 1876, Major Henry M. Robert, a United States Army Engineer, wrote what became the most popular book on parliamentary procedure, Robert's Rules of Order. Always, the will of the majority must be implemented or effected, while the will and rights of the minority must be respected.

\section{Methods of Voting}

1. By the show of hands

2. By the living Voice (viva voce)

3. By Standing

4. By Secret Ballot

5. By Electronic means

6. By General/ Unanimous Consent or acclamation (consensus)

7. By Roll Call.

8. By color cards 
Plurality is the largest number of votes received by any candidate in an election involving three or more candidates.

Point of order is an objection raised by a member because of improper procedure or annoying remarks. It must be ruled upon immediately by the presiding officer.

Question of Privilege is a request that is made by a member who asks the presiding officer to deal with an emergency, disorder in the assembly, or other matters of general or personal welfare.

\section{GENERAL CONFERENCE RULES OF ORDER (HANDOUT)}

\section{REFERENCES}

Gane, A. Barry. Building Youth Ministry: A Foundational Guide. Riverside, CA: La Sierra University Press, 1997.

General Conference of Seventh-day Adventists. General Conference Rules of Order.

Hagerstown, MD: Review and Herald Publishing Association, 2000.

Haynes, Marion. Effective Meeting Skills. Menio Park, CA: Crisp Publications, Inc, n.d.

North American Division. Pathfinder Instructors Awards Manual. Hagerstown, MD: Review and Herald Publishing Association, 1995.

Shearer, Ned A. "Parliamentary Procedure," World Book Online Americas Edition, http:/www.aolsvc.worldbook.aol.com/wbol/wbPage/na/ar/co/415460, February, 19, 2002. 


\title{
CHURCH LEADERS-IN-TRAINING EMPOWERMENT PROGRAM BROOKLYN TEMPLE OF SDA
}

\author{
Sermon Preparation and Dolivery
}

Thursday, May 9, 2003

7:00-9:00 pm

by

Pastor Newton U. Cleghorne

Youth Director Northeastern Conference of Seventh-day Adventists 


\section{SERMON PREPARATION AND DELIVERY \\ Presented by Pastor Newton U.Cleghorne}

Text Books: The Preacher and His Preaching by Charles E. Weniger

Preaching to the Times by Charles Bradford

What is the meaning of a Sermon?

A sermon is the sum total of the messenger and the message saturated by and in the Word of God, bathed in the power of the Holy Spirit and delivered to an audience. The word preached by the preacher is not his, it is God's. If the message is not God's it is not a sermon it is a speech, and therefore is purely human. It is lifeless and can effect no change. When a message is from God it will effect change and cause its hearers to desire a new direction for their lives.

The Medium plus the message equals the Sermon.

What is Homiletics?

Homiletics is the art or Science of preaching. A sermon is therefore called a homily.

What are the Mechanics of Sermon Preparation?

A Sermon has three parts-An Introduction, a Body/Discussion and a Conclusion or Appeal

The Introduction provides the general background for the sermon, the Body is the heart and core of the sermon and the Conclusion is the summary of the sermon that has as one of its components, a challenge to the hearers to do something about what they have heard. 
The way a sermon is outlined is:

\author{
Sermon Topic \\ Key Text: \\ Introduction \\ Body \\ Conclusion (Never say "in conclusion" unless you
}

mean it.)

How do you develop a sermon? Just like a shoemaker crafts a shoe out of a mold or a potter produces a piece of pottery out of clay, so the preacher must use certain tools to produce his sermon. The Preacher must have a hunch, a burden, a desire, a compulsion to satisfy a need of a congregation or audience. Driven by that inexplicable passion to come to an understanding of that which disturbs your soul, the preacher starts out on a mission-an information-gathering mission to satisfy that burning desire to bring a word to a people. The preacher now must craft a sermon. Let's look at the work

\title{
CRAFT:
}

$\mathrm{C}$ means collect and categorize

$\mathrm{R}$ means research and reflect

A means apply (three kinds of people in your audience-Auditory (hear), Kinesthetic (feel) and Visual (see).

F means fashion and flavor (illustrations, words picture and humor)

T means trim and tie together 
What are the types of Sermons?

There are many types of Sermons, but the ones we will deal with here are:

Biographical: Tells of a Bible character (Joseph, Moses, Sampson, Joshua, David, etc.)

The outline would look like this:

Topic: Joseph (From Slave to Ruler)

Key Text: Genesis 37:1-11

Introduction:

What does his name mean.

His family background

The situation with his father and the coat of many

colors

His sale to the Ishmaelites

$B O D Y$

In Egypt

Potiphar's House

In Prison

Interpretation of Pharaoh's Dream

Promotion to Prime minister of Egypt

His family come to Egypt

The revelation of himself

The Reunion

Conclusion 
Be careful of favoritism

Be careful of other sins

Faithfulness counts, even unto death

One day, God will be united to us.

Topical: A General Topic-The Day the Towers fell

Expository: Explaining a Passage of Scripture (Do not come to the Scripture with a closed mind coupled with your presuppositions. We must come to Scripture with an opened mind. Come as an exegete not as an eisegete.

Narrative: A Story (Bible Story)

Textual: Based upon a text or several texts

Remember, BTENT

What are the types/modes of Delivery?

Outline-Jot down the main points

Extemporaneous-Just on the spur of the moment

Memory-Preach from memory

Manuscripts-Sermon written out word for word for the most part.

Electronic-computers with power point presentation, etc,

-Video, big Screens

What part does the Voice play in the delivery of a Sermon?

The preacher's voice is his chief stock in trade. It is your messenger...make it a bearer of goodwill. In Christ's Objectsessons, 
335:

The power of speech is a talent that should be diligently cultivated. Of all the gifts we have received from God, none is capable of being a greater blessing than this. With the voice we convinced and persuade; with it we offer prayer and praise to God and with it we tell others of the Redeemer's love. How important, then, that it be so trained as to be most effective for good.

Speak from the diaphragm not from the throat. It is called diaphragmatic voice production.

Learn to breathe properly:

Hold your breath and say Hosanna

Sniff and keep it and say Hallelujah

The voice captures the attention, so it is crucial that you use it and care it. Talk with your chest. Talk with your diaphragm. Practice, practice, practice. We need to achieve projection, not screaming and hollering. Draw in your abdomen, pulling it upward and backward.

Practice reading these verses: Isa $40: 1-5 ; 52: 1,2 ; 58: 1 ; 60: 1-3,61: 1$

Your grammar, your pronunciation. H's, d's, th's, s's. Practice, practice, practice. Pathos and appeal in the voice.

What importance, if any, should be attached to the Dress, grooming and manners of the preacher?

Remember, the preacher is seen before he is heard. The audience read your 
clothes before they read your Bible. From head to toe, reflect everything that is in good taste. Let's start from the head.

\section{Think on these things:}

Never think that you have learned enough, and that you may now relax your efforts. The cultivated mind is the measure of a man. Your education should continue during your lifetime; every day you should be learning, and putting to practical use the knowledge gained. 4T561.

God's appointed means of saving souls is through the foolishness of preaching. $5 \mathrm{~T} 300$.

The world will not be converted by the gift of tongues, or by the working of miracles, but by preaching Christ crucified. Testimonies to Ministers, 24 . We are not called to preach the times. We are called to preach to the times. If we can keep this in mind, it will save our preaching from being a pedestrian running commentary on current events sprinkled with a few Bible texts and quotations from Ellen G. White. Preaching to the Times, 11.

Now you have been given the tools of the trade, practice in order to achieve excellence. First prepare thy heart; then prepare thy sermon" Preaching is not merely organizing theological ideas and presenting them to a congregation. Preparing to preach a sermon does not consist merely in taking one's pen or computer in hand, organizing an outline, developing the divisions of the outline, clothing ideas in appropriate language, and making sure that the delivery will be acceptable to the hearers.

Preparing to preach is al this, but it is much more, for these are only matters of 
immediate preparation. Wider preparation involves a life of consecration. It involves a life of consecration.

It requires the surrender of the preacher's whole being to the direction of God. It demands that the minister's heart be prepared before the mechanical details of the sermon can be prepared. The preacher must be converted before he can be instrumental in converting others. First, prepare thy heart...then prepare thy sermon is sound advice. When Scotland was deep in apostasy, John Knox's preaching shook the foundation of apostasy and transformed Scotland into a Christian nation.

When Europe was steeped in Roman Catholicism, it took a Martin Luther to shake its foundation and introduced the doctrine of righteousness by faith.

When the early Christian church was initiated by the decent and baptism of the Holy Spirit, the preaching of the apostles turned the world upside down. Peter with the other disciples' preaching, netted three thousand souls in one day and five thousand from the ripple effect.

\section{Preachers' Clinic:}

No matter how well you can define the types of sermons and the modes of delivery and how to construct or craft a sermon, you can only be an excellent preacher if you practice, practice and practice. Yes, practice becomes perfect.

Preach a five-minute sermon, tell the kind of sermon and the type of delivery. What about the development and the appeal? Did the preacher call the listeners to make a decision for Jesus. 
Did the preacher just circled the airport, or did he land the aircraft? What about the preachers grooming and manners, diction, pronunciation, grammar? 
CHURCH LEADERS-IN-TRAINING EMPOWERMENT PROGRAM

BROOKLYN TEMPLE SEVENTH-DAY ADVENTIST CHURCH

CHRISTIAN STEWARDSHIP FROM A BIBLICAL PERSPECTIVE

by

Pastor Newton U. Cleghorne

Youth Ministries Director and Stewardship Specialist

Northeastern Conference of Seventh-day Adventists

Sabbath, June 8, 2002 


\section{INTRODUCTION}

The biblical and theological concept of Stewardship dates back to the Garden of Eden when God, the Owner of all-created beings, the world and all that is in it, established that principle. He made Adam and later Eve custodians, keepers and managers of the Garden of Eden. He referred to their job description as having 'dominion over the fish of the sea and over the fowls of the air and over every living thing that moveth upon the earth' Gen. 1:28a. Dominion makes man responsible to God for what he does with the earth. It is not ownership that man has, but proprietorship and management. To show His ownership of all and as a reminder to Adam and Eve, God told them not to eat of the tree of knowledge of good and evil. They could eat of every other tree in the garden, but this one they should not touch nor even go near to it. God was establishing His authority as Owner, Creator, and Sustainer of the Universe.

After man succumbed to the snare of the tempter by eating of the forbidden tree, God sought to restore man back to his original stature. He promised man, in the declaration of the protevangellion ( the first announcement of the plan of salvation (Gen 3:15), that He would devise a plan whereby He would win man back from the clutches of the Devil. Essentially, He promised Himself to be the final Sacrifice that would be slain to redeem man.

What is stewardship? Who is a steward? and what is God's requirement for stewards? In 
order to answer these questions, this paper will define the terms stewardship and steward. The paper will seek to look at the various aspects of stewardship, take an historical view of stewardship and bring a focus on Christian financial stewardship. The paper will also discuss the call of the prophet Malachi in Chapter 3, focusing on renewal, faithfulness and accountability ending the Old Testament era.

The paper will also address the New Testament stewardship motif advanced by Jesus, His apostles and prophets. Finally, the paper will look at financial stewardship in the context that it is the only measurable aspect of stewardship, thus giving rise to the need to be more faithful in the giving patterns of Christian stewards. 


\section{Chapter I \\ Stewardship Defined}

Before the subject of stewardship can be clearly defined, the subject of ownership must be addressed. God is before all things. The foundation of all existence is God. We do not understand what that means in totality because "His ways are past finding out", but what God has revealed to us we believe. Gen 1:1, "In the beginning God." Ps 90:2, "From everlasting to everlasting thou art God."

According to Paul G. Smith in his expression of his concept about God's eternity and ownership:

Before the creation of the worlds, God was. Before all else, God is! Confused man had made himself many gods-gods of stone, flesh, steel, wood, plastic, even self. But such things are not God. They are either something man has made, or they are the creation of God. Man does not make God, God is what He is...God lived before creation. He therefore exists distinctly above and beyond what $\mathrm{He}$ created. He is not dependent upon His creation, but it is upon Him. ${ }^{1}$

God created all things. Gen 1 and 2 describes the week of creation and details all that God provided for man's happiness, including an help meet. God gave man dominion over

'Paul G. Smith, Managing God's Goods, (Nashville, Tennessee : Southern Publishing Association, 1973), 10-11. 
everything, but made it clear that the holy pair should not eat, touch nor go near the tree of knowledge of good and evil (Gen 2:16,17). This was His way of reminding Adam and Eve that they did not own anything, but they were mere caretakers, managers, overseers and stewards.

In addition to the creation story, the Bible is replete with examples of God as owner. Hag 2:8 states that all the silver and gold belongs to God. Ps 50:10 declares that every beast, every cattle, all the fowls and wild beasts belongs to God. Ps 24: 1 states, "The earth is the Lord's and the fullness thereof, the world, and they that dwell therein." Ps 100:3a is very clear: "we are his people, and the sheep of his pasture." More than all, Duet 8:18 reminds that it is God who gives power to get wealth. In 1 Cor 6: 19,20, Paul uses God's ownership of the human body as a reason to abstain from fornication.

The pagan religion says " 1 . That people are the absolute owners of all they can get 2 . Use what you have as you please 3. The supreme purpose of life is to get 4 . The ideal of paganism is acquisition and 5 . Life is like a grab bag."

In diametric opposition to this teaching, Christianity teaches " 1 . That we own nothing in our own right 2 . Use what you have as God wants 3 . The supreme objective of life is to give 4 . The ideal of Christianity is contribution and 5 . That life must be seen as a priceless opportunity for service. ${ }^{\prime 3}$

In The Seventh-day Adventist Bible Commentary, Vol. 6, Ellen G. White, under inspiration

${ }^{2}$ Marvin Moore \& Edwin Froom, Discoveries in Partnership (Boise, Idaho: Pacific Press Publishing Association, 1999), 26.

${ }^{3}$ Ibid. 
wrote:

Man does not belong to himself; he has no right to use his powers according to the wishes and promptings of his unconverted body. He is the property of God by creation and by redemption. Man is bound to live mentally, physically, and spiritually as God directs, to the glory of His name, and not to the gratification of fleshly desires. The converted man is, indeed, a willing slave of Jesus Christ,... who lives only to please his Master. ${ }^{4}$

Every human being on earth is a steward. Man's stewardship responsibility does not depend upon the quality or quantity of his material possessions. Whether Christian, Muslim, Jew, Zoroastrian or atheist, mankind has a stewardship obligation to God on the single basis that he has life.

The word stewardship is derived from two Greek words, oikos meaning house and nomos meaning law. From these two words we derive the word, steward which means, bond-servant of the King. Too often we have equated stewardship only with money and other material possessions because of the fact they are the measurable commodities in the stewardship concept. However, man's stewardship began before the existence of money. Stewardship, then, involves all that man has and is. Stewardship involves a relationship and a partnership between God and man that God is seeking to reestablish. The fall of Adam and Eve in the Garden of Eden fractured the face-to-face relationship that man had with his God. God has been seeking to restore that relationship. To fulfill this, and in order for the partnership to develop and endure, there must be the establishment and maintenance of certain unchanging realities. God's ownership of everything is one of them.

${ }^{4}$ Francis D. Nichol, Editor, The Seventh-day Adventist Bible Commentary, Vol. VI, (Washington DC : Review and Herald Publishing Association, 1980), 703. 
In Myron Widmer's article "Partners With God", he strongly supports the concept that ... Stewardship isn't about money. It's about a relationship, a trust relationship between the Creator and His creation." To believe in stewardship is to affirm that God exists. And to affirm God's existence is to believe in stewardship. They are inextricably tied together, for at the basis of all stewardship is the fact that God exists and that He is the Creator (Gen 1:1), Owner (Psalm 24:1), Sustainer (Heb 1:3; Acts 17:28), and Redeemer (Ps 19:14) of us and the entire universe. ${ }^{5}$

Stewardship confirms our relationship with God as a person. Through the exercise of our stewardship responsibilities, God becomes more real to us. Before, we accepted His existence through intellectual faith. Now it becomes a reality. "The sense of God being present in our daily lives restores Him to His rightful place as Creator, King and Ruler of individual lives." Stewardship, then, is grounded in the Creator-creature relationship, in the affirmation of the God who is continually creating, redeeming and empowering human life.

In his masterpiece on stewardship Harold Lee suggests:

The life of stewardship is an on-going process of integration whereby we relate our whole person to the whole action of God: The life of stewardship calls us to unity of purpose: the seeking of the wholeness of human life in communion with God. By acknowledging our dependence upon God for all of life, we are called to regard material things and human capacities not as private possessions or as personal property, but as God's gift. ${ }^{7}$

${ }^{5}$ Myron Widmer, "Partners With God: We Must Manage But God Owns.", Adventist Review, September 1992, 8.

${ }^{6}$ Smith, 12.

${ }^{7}$ Harold Lee, New Perspectives on Christian Stewardship, n.p., 8-9. 
By accepting our calling as stewards we affirm our calling to serve as God's instruments of love, to proclaim the new life to be found in Jesus Christ, and to utilize the gifts of the Spirit given to us in service to and God and to the world.

In her contribution to the concept of stewardship, Laurie S. Herr adds:

A steward is someone who manages the affairs of another. Luke describes the steward as a "faithful and wise" manager. ...the manager handles his master's affairs while he is away. When the master returns, he praises his manager (or steward) for his loyalty [or chastises him for his disloyalty]. Christian stewards today manage the affairs of God. But in order to do this in a way that will earn His praise, we must view life from His point of view and use His priorities in the expenditure of our time, talent, temple and treasurer. ${ }^{8}$

Man's stewardship is a tremendous privilege and responsibility. In fact, it is difficult to believe or to even imagine that God would make man in His image and after His likeness. It is an awesome honor. Thus, to safeguard the image of God in him is man's first responsibility as a steward under God. To buttress this concept and to get to the core of the basis for stewardship, the apostle Paul concurs in 1 Cor 4:1,2: "Let a man so account of us, as of the ministers of Christ, and stewards of the mysteries of God. Moreover it is required in stewards, that a man be found faithful."

Larry Burkett, America's foremost authority on personal finance, in his sought-after anthology on finance, penned very profoundly:

The key to realizing God's will in finances is a proper understanding of stewardship. God will not force His will on us, but once a Christian accepts the role of stewards and manages God's resources according to His direction, God will entrust more and more to that person.

Christians have become victims of one of the most devious plots Satan ever created-the concept that money belongs to us and not to God. Indeed, every thing we own belongs to God-including money. We cannot experience peace in the

${ }^{8}$ Laurie S. Herr, Managing Your Resources (Boise, Idaho: Pacific Press Publishing Association, 1989), 5-6. 
area of finances until we have surrendered total control of this area to God and accepted our positions as stewards. God is the owner. We are the stewards. ${ }^{9}$

Life is man's one great single possession. Stewardship then can be defined as involving the wise and unselfish use of life. So that man may develop character for eternity, God gave man the power of choice to be able to properly effect his stewardship of life.

Ellen G. White under inspiration informs:

Though created innocent and holy, our first parents were not placed beyond the possibility of wrongdoing. God might have created them without the power to transgress His requirements; but in that case there could have been no development of character; their service would not have been voluntary, but forced. Therefore, $\mathrm{He}$ gave them the power of choice-the power to yield or to withhold obedience. And before they could receive in fullness the blessings $\mathrm{He}$ desired to impart, their love and loyalty must be tested. ${ }^{10}$

Man, created to exercise dominion over all the world, must learn to handle the power of choice in his own life. He must demonstrate that God can trust him with eternal existence.

According to Harold Lee in defining stewardship in New Perspectives on Christian

\section{Stewardship:}

Stewardship is a metaphor that sums up the meaning of Christian life. It is one of the most exciting and inclusive of all Christian symbols. Understood in its biblical/theological context, stewardship is the goal of discipleship. It is the root of mission, the energy of ministry, and the model for Christian lifestyle individually and corporately. ${ }^{11}$

${ }^{9}$ Larry Burkett, Dollars and Sense (Uhrichville, Ohio : Barbour and Company, Inc.,1993), 97,197. 23.

${ }^{10}$ Ellen G. White, Education (Boise, Idaho : Pacific Press Publishing Association, 1903),

${ }^{11}$ Harold Lee, 4. 
The concept of the steward is inextricably bound to the concept of stewardship. It is deeply rooted in the biblical story. Beginning with Adam and Eve to the covenant with Abraham to the pilgrimage of the Hebrew People and unto the New Testament churches. The steward was a person put in charge of someone else's property. The steward is a servant, someone, who, because of his or her attitude and relationship has been given the responsibility for the management and service of something belonging to another. Ultimately, the steward is held accountable and answerable to his master for the faithful and wise management of the possessions left in the steward's hands.

A close relationship exists between the steward and his master exemplified in the cases of Eleizer to Abraham (Gen 24:1-67) and Joseph to Pharaoh, king of Egypt (Gen 41:25-27).

In the New Testament, the concept of steward takes on an added meaning. There is a shift from the trusteeship model to the partnership model. The steward is now adopted into the family of God and becomes a joint heir, entering a new level of relationship with God. "Thus in Ephesians 1:3-13, stewardship becomes partnership in God's activity as we join in the work of Christ to bring the creation to wholeness, to bring about salvation." 12 In Luke 12:41-48, Christ is portrayed as the Master and the disciples as the stewards. The disciples are entrusted with responsibility for the faithful and wise management of the "household of God"-the church.

In 1 Cor 3:22, Jesus is portrayed as the Master steward, the perfect servant of God. Jesus Christ is portrayed as the primary steward of God's grace, defining and fulfilling the office of the steward. "He lives in such complete obedience to his stewardly vocation that he becomes both

\footnotetext{
${ }^{12} \mathrm{Ibid}, 13$.
} 
the medium through whom God's gifts are distributed to others and the primary model for our stewardship." $" 13$

In most churches today, the word stewardship unearths distasteful thoughts and feelings about difficult every-member visitations, building funds, financial campaigns, concerts, rummage sales, bake sales and all types of fund-raising techniques. Even some pastors shudder at the thought because it reminds them that they must become fund-raisers-something for which they have not been trained and with which they feel great discomfort.

Macchia was right when he postulated:

Stewardship and generosity are where the rubber meats the road in our lifestyle as Christians. The healthy church is filled with generous, wellintentioned and cheerful givers of time, talent, and finances. By contrast, we live in a world that is absorbed with the almighty dollar. We are encouraged to pursue financial gain at all costs, even at risk of our own reputations. But we better not get so caught up in these pursuits that we find ourselves involved in schemes that will hurt the expansion of the gospel or our collective witness as the body of Christ. $^{14}$

In its broadest sweep, Christian stewardship is more than money. It encompasses the Gifts of Creation and Life and calls us to be stewards of the earth and its cosmic environment, talent, time, the body temple and material possessions. It also focuses on the Gifts of Redemption which calls us to be stewards of the Gospel and the Church of Jesus Christ. Finally, Christian stewardship highlights the Gifts of Empowerment calling us to be stewards of Spiritual Gifts and Gifts of Ministry.

\footnotetext{
${ }^{13}$ Ibid., 14.

${ }^{14}$ Stephen A. Macchia, Becoming A Healthy Church (Grand, Rapids, Michigan : Baker Books, 1999), 198.
} 


\section{Chapter II}

\section{The Stewardship of Creation and Life}

Creation brought human beings into being as the Lord formed man from the dust of the ground and breathed into his nostrils the breath of life and man became a living soul. Gen 2:7. The subsequent making of Eve finished the human creation of male and female.

Dominion, labor and responsibility comprised an important part of Adam and Eve's personal development. God fashioned mankind to act as steward of his own life as well as the rest of the creation over which God had placed him. Not only God, but all heaven took a deep interest in man. "If man was to appreciate the joys and privileges of God's family, he must learn to use his life wisely and without selfishness. He must not repeat the sin of Lucifer and let self-interest rob him of the higher interests and joys of the heavenly family." 15

Adam and Eve clearly understood their stewardship responsibilities as well as the joys of personal association with God. Sin, the unwise and selfish use of life, would bring disharmony and unhappiness to them just as it had previously done to Lucifer, and it would lead to death. That is the reason for God to put them on full alert that "He [Satan] could have access to them only at the tree of knowledge of good and evil."16

${ }^{15}$ Smith, 17.

${ }^{16}$ White, The Story of Redemption (Hagerstown, Maryland : Review and Herald Publishing Association, 1980), 31. 
Hence, the necessity for them not to go near, touch nor eat of the fruit of the tree.

When someone mentions stewardship, a majority of people immediately think of money or material possessions. When looked at from its most significant point, stewardship involves life. Even man's life belongs to God; the Creator.

God gave man life, instructed him to use it, and tested him on how he employed it. If man learned to utilize life wisely and unselfishly, he would have eternal life. If he did not, he would suffer the consequences. The use of the gift of the power of choice would determine on whose side man would stand. So in the stewardship of life:

God created man for His own glory, that after test and trial the human family might become one with the heavenly family. It was God's purpose to re-populate heaven with the human family, if they would show themselves obedient to His every word. Adam was to be tested, to see whether he would be obedient, as the loyal angels, or disobedient. If he stood the test, his instruction to his children would have been only of loyalty. His mind and thoughts would have been as the mind and thoughts of God. He would have been taught by God as His husbandry and building. His character would have been molded in accordance with the character of God. ${ }^{17}$

God's tests of life involve man's use of life. Life consists of four basic ingredients: the body temple, material possessions or treasure, abilities or talents and time. These are the gifts of life that God gave to mankind. These are they which man must pass in order to be accounted worthy of the description of "good and faithful." Man acknowledged God's ownership of life by lovingly, systematically, and unselfishly, returning that portion of life which God specifically claimed.

${ }^{17}$ Francis D. Nichols, Editor, Seventh-day Adventist Bible Commentary, Vol.1, 1082. 
God tested man in regard to the ownership and use of the body by giving him a plan to follow for healthy living. He examined man on material possessions by reserving for Himself the tree of knowledge of good and evil. He tested man's handling of abilities by giving him responsibilities which involved mental and physical labor. Finally, God puts man's stewardship of time to the test by reserving the Sabbath as a day of rest, during which God and man would spend the time together. 


\section{Chapter III}

\section{Stewardship of the Body Temple}

From the beginning, God has sought for man to have a vibrant physical body. Gen 2:7 informs that God breathed into the perfectly designed body of man the breath of life and man became a living soul (human being). It is that body that God expects us to be faithful stewards of. Psalms 139:14 tells us that we are faithfully and wonderfully made. 1Cor 6:18-20 informs that our body is God's temple.

He who created the body explained His ownership of it and offered specific directions for its care and use. Psalm 100: 3. As a means of keeping man's body clean, healthy and holy, God gave man a diet for him to experience longevity and to serve Him faithfully. For food, Adam and Eve received the seed-bearing plants and the trees with seed-bearing fruit. To all animals God gave the foliage of plants. Gen 1:29. Since fruits, grain and nuts were available in diverse and plentiful quantities, the first members of the human race had no thought or need of killing for food. God is presently encouraging His earthly family, wherever and whenever possible, to again follow His original dietary concept.

God presented the proper relationship of labor, rest, recreation, diet, companionship and other essential elements of healthful living. This divine program is even more essential today than in Eden, for the effect of centuries of sin upon the human body has weakened it beyond comprehension. 
God has given us eight natural remedies to keep our bodies free from disease. They are Nutrition, Exercise, Water, Sunshine, Temperance, Air, Rest and Trust in God. These eight words produce the acronym NEWSTART. If this concept were to be tweaked in another way it would read STEWARDS: $\mathrm{S}$ for Sunshine, $\mathrm{T}$ for Temperance, $\mathrm{E}$ for Exercise, $\mathrm{W}$ for Water, A for Air, R for Rest and D for Diet and S for Salvation. If we follow these basic principles, we will experience optimum health and longevity.

The apostle Paul was right on target when he wrote in Romans 12:1, "I beseech you therefore, brethren, by the mercies of God, that ye present your bodies a living sacrifice, holy, acceptable unto God, which is your reasonable service." 


\section{Chapter IV}

\section{Stewardship of Time}

Time is God's gift to be used in God's service as we are involved in God's creative activity in the world. There are several words used in the New Testament Greek to refer to time: Kairos, Chronos and Aion. Kairos is concerned with a point in time filed with special meaning. We are to be watchful for such times, unlike the foolish virgins who missed their opportunity (Matt 25:13). Chronos refers to a certain period or span of time, is also to be managed carefully. Aion refers to the new age of endless time-eternity- in which we are to live in hope (Rom 8:24). To be a steward of time implies the discovery of God's kairos in the midst of our life span (chronos).

He who is eternal explained to Adam and Eve that time comes from Him and belongs to Him. As a reminder of His creative power and ownership, God reserved the Sabbath as a day of rest, a time when God and man would especially be together. Through the Sabbath the human and heavenly families were to grow closer together. Exodus 20:8-11 tells us to "Remember the Sabbath day to keep it holy."

When one keeps the Sabbath one has not given God any time. Sabbath time is not our time in the first place. It is God's. To offer God a gift of time, one must take it from the other six days.

In Eden Adam and Eve did not spend only the Sabbath hours with God, but each day, besides 
the regular times spent in cultivating the earth, they looked forward to walking and talking with their Maker. Their special time for daily fellowship with God became the high point of each day. Today, daily worship and prayer is God's plan for us to substitute for the Edenic communion and fellowship.

God was very specific in detailing how man would use his time as Adam and Eve enjoyed the bliss of Eden, "A portion of their time was to be occupied in the happy employment of dressing the garden, and a portion in receiving the visits of angels, listening to their instruction, and in happy meditation."

${ }^{18}$ White, Story of Redemption, 21. 


\section{Chapter V}

\section{The Stewardship of Talents}

When God made man he endowed him with abilities sufficient for him to be useful and industrious and to enjoy the benefits of those gifts. The stewardship of the talents that God continually gives to us is best expressed by acknowledgment of our true vocation: our calling to be servants of God. We are expected to be loving and caring stewards of the creation and of all its creatures, including ourselves, and the special talents we have been given.

In her book, Counsels on Stewardship, Ellen G. White informs:

God has lent men talents-an intellect to originate, a heart to be the place of His throne, affection to flow out in blessings to others, a conscience to convict of sin. Each one has received something from the Master, and each one is to do his part in supplying the needs of God's work.

God desires His workers to look to Him as the Giver of all they possess, to remember that all that they have and are comes from Him who is wonderful in counsel and excellent in working. The delicate touch of the physician's hand, his power over nerve and muscle, his knowledge of the delicate organism of the body, are the wisdom of divine power, to be used in behalf of suffering humanity. The skill with which the carpenter uses the hammer; the strength with which the blacksmith makes the anvil ring, come from God. He has entrusted men with talents, and He desires them to look to Him for counsel. Thus they may use His gifts with unerring aptitude, testifying that they are workers together with God. ${ }^{19}$

${ }^{19}$ White, Counsels on Stewardship (Tacoma Park, Washington, D.C.:Review and Herald Publishing Association, 1940), 114. 
By fulfilling God's requirements, man demonstrated his loyalty to God's government and acceptance of God's ownership of his abilities. That is the reason God created the environment that gave man the opportunity to maximize his talents and abilities in the care of the earth:

To Adam and Eve was committed the care of the garden, 'to dress it and to keep it.' Though rich in all that the Owner of the universe could supply, they were not to be idle. Useful occupation was appointed them as a blessing, to strengthen the body, to expand the mind, and to develop the character. ${ }^{20}$

Property, speech, strength and influence are talents to be used to the honor and glory of God. In the Lord's plan there is a diversity in the distribution of talents. The parable of the talents is a clear demonstration of how God distributes his bountiful blessings in talents and abilities according to the capability of the recipient. To one the master gave one, to another two and to another five. The master leaves for a time and then returns to see how faithful and wise these servants were in the use of their talents and hold them accountable. "The parable of the talents, rightly understood, will bar out covetousness, which God calls idolatry."21 Echoing the sentiments of Ellen G. White, Stephen A. Macchia adds: "The Parable of the talents in Matthew 25 is an excellent place to stop and reflect on the subject of life and stewardship... It speaks of judgment, anticipation of Jesus' ultimate return, and our response as his children. It is a simple story with powerful and profound implications for all of us as followers of Christ." ${ }_{22}$

To whom much is given, much is required. This is God's expectation for His stewards in the use of their talents and abilities. Continuing in the vain of thought:
${ }^{20}$ White, Education, 21.
${ }^{21}$ White, Counsels on Stewardship, 114.
${ }^{22}$ Stephen A. Macchia, Becoming A Healthy Church (Grand Rapids, Michigan: Baker Books, 1999), 201. 
According to the talents bestowed will be the return called for. The heaviest obligation rests upon him who has been made a steward of the greatest abilities. A man who has ten pounds is held responsible for all that ten pounds would do if used aright. He who has only ten pence is accountable for only that amount.

It is the faithfulness with which the endowment has been used that wins the Lord's commendation. If we desire to be acknowledged as good and faithful servants, we must do thorough, consecrated work for the Master. He will reward diligent, honest service. If men will put their trust in Him, if they will recognize His compassion and benevolence, and will walk humble before Him, He will cooperate with them. He will increase their talents. ${ }^{23}$

The talents God has endowed us with are not to be used to glorify self, but to glorify God and be a blessing to humanity.

${ }^{23}$ Ibid., 116. 


\section{Chapter VI}

\section{Stewardship of Material Possessions}

Already established is the fact that material possessions, which includes money are not the only focus of stewardship. This is only one aspect of it. Nevertheless it becomes the only measurable aspect of stewardship. A great emphasis is therefore placed on this aspect, because we can see it, count it and touch it.

God informed Adam and Eve that they could have access to all things in the Garden of Eden, except one tree-the Tree of knowledge of good and evil. God drew the dividing line between Himself as Owner and Adam and Eve as Stewards. He declared, "Of every tree of the garden thou mayest freely eat: but of the tree of the knowledge of good and evil, thou shalt not eat of it: for in the day that thou eatest thereof thou shalt surely die." Gen 2: 16,17.

Commenting on the significance of the Tree of knowledge of good and evil, White cites, "This tree God reserved as a constant reminder of His ownership of all. Thus He gave them opportunity to demonstrate their faith and trust in Him by their perfect obedience to His requirements. ${ }^{.24}$

${ }^{24}$ White, Testimonies to the Church, Vol. 6 (Mountain View, California: Pacific Press Publishing Association, 1848), 386. 
When Adam and Eve sinned by eating of the forbidden tree, they lost the privilege of living in the Garden of Eden. Subsequent to their fall, God replaced the constant symbol of His ownership of material possessions by establishing the tithing system.

In Seventh-day Adventists Believe, the concept of the tithing system is clearly described:

To remind us that He is the Source of every blessing, God instituted a system of tithes and offerings. This system eventually provided the financial means for supporting the priest-hood of the Israelite temple. Seventh-day Adventists have adopted the Levitical model as a sound, Biblical method for financing a worldwide outreach of the gospel. God has ordained that sharing the Good News is to be dependent on the efforts and offerings of His people. He calls them to become unselfish co-laborers with Him by giving tithes and offerings to Him. ${ }^{25}$

For purposes of definition, a tithe is a tenth. The Scriptures is replete with vignettes of individuals returning tithes or with the discussion of the tithing concept. The first practical demonstration of the tithing principle was unveiled by Abraham who gave "a tithe of all" to Melchizedek, the priest of the Most High God Gen 14:20. By doing so, he acknowledged Melchizedek's divine priesthood and showed that he was well acquainted with this sacred institution.

Jacob, an exile and fugitive, vowed to the Lord, "Of all that You give me I will surely give a tenth to You."(Gen 28:22). After the Exodus, when Israel was established as a nation, God reaffirmed the law of tithing as a divine institution on which Israel's prosperity depended.(Lev 27:30-32, Numbers 18:24-28, Duet 12:6-17).

It is worthy of note that the last book of the Old Testament heralds the need to be faithful to God, the Owner of all possessions. It is not only an appeal to faithfulness, but a call to a revival and reformation in the management of God's financial resources. Malachi 3:7-12.

${ }^{25}$ The Ministerial Association General Conference of S.D.A., Seventh-day Adventists Believe (Hagerstown, Maryland: Review and Herald Publishing Association, 1988), 271. 
The New Testament continues the support of the biblical principle of tithing. Jesus approved tithing and condemned those who violated its spirit (Matt 23: 23). There are some who would suggest that tithing was under the ceremonial law. There is however clear light that this assumption is unbiblical and unfounded, "While the ceremonial laws regulating the sacrificial offerings symbolizing Christ's atoning sacrifice ended at His death, the tithing law did not.,"26

How should the tithes be used? This is the question that has surfaced like a recurring decimal in the mathematics of those who desire to be faithful in their financial stewardship commitment to God. The Bible is clear, "And all the tithe of the land, whether of the seed of the land, or of the fruit of the tree, is the Lord's: it is holy unto the Lord. And concerning the tithe of the herd, or of the flock, even of whatsoever passeth under the rod, the tenth shall be holy unto the Lord" (Lev.27:30,32).

The prophet Malachi was clear regarding the fact that the tithe must be brought into the storehouse, "Bring ye all the tithes into the storehouse, that there may be meat in my house." Mal 3:10. What is the storehouse? Within the context of Seventh-day Adventism, the local church first receives the tithes, then remits it to the local conference treasury-the clearing house of the funds to be distributed by the Union to the outer levels of the organization-the Division and General Conference.

In Israel the tithe was used exclusively for the Levites, who, having received no tribal allotment, were to use all their time in fostering Israel's worship, ministering at the sanctuary, and instructing the people in the law of the Lord (Num 18:21,24).

\footnotetext{
${ }^{26} \mathrm{Ibid} ., 272$.
} 
After the death of Jesus Christ which caused the abrogation of the ceremonial system, tithes were still to be used to support the mission of the church. Paul, with his unusual brilliance illustrated the principle underlying this by drawing a parallel between the Levitical service and the newly established gospel ministry. He states, "Do you not know that those who work in the temple get their food from the temple, and those who serve at the altar share in what is offered on the altar? In the same way the Lord has commanded that those who preach the gospel should receive their living from the gospel" (1 Cor 9: 13,14, NIV).

Some individuals vacillate regarding the certainty of the use of the tithe. However, Ellen G. White under inspiration makes it abundantly clear:

God has given special direction as to the use of the tithe. He does not design that His work shall be crippled for want of means. That there may be no haphazard work and no error, He has made our duty on these points very plain. The portion that God has reserved for Himself is not to be diverted to any other purpose that which He has specified. Let none feel at liberty to retain their tithe, to use according to their own judgement. They are not to use it for themselves in an emergency, nor apply it as they see fit, even in what they may regard as the Lord's work. ${ }^{27}$

In an effort to nail down the use of the tithe to its most detailed designation and specificity, Ellen White adds, "This fund [the tithe] should not in any case be devoted to any other use; it is to be devoted solely to support the ministry of the gospel."28

The tithe is not the only monetary requirement that God expects. Although, He is not as specific in the amount as He does the tithe, he requires us to bring a liberal offering. In the book of Malachi 3:8, it refers not only to God's concern regarding our faithfulness in returning the

\footnotetext{
${ }^{27}$ White, Counsels on Stewardship, 101.

${ }^{28}$ Ibid, 81 .
} 
tithe, but offering also. The question is asked, "Wherein have we robbed Thee?" The answer comes, "In tithes and offerings."

After the ten percent of our income is returned to God, we are left with ninety percent, which is still not ours, because we own nothing. It is from this remaining amount, God expects us to set aside an offering to help care for additional needs of His cause. The concept of what goes beyond the tithe is expressed cogently by Smith:

When you have honestly returned the tithe, you have not given God any money. The tithe is not yours in the first place. It is already God's money. If you would donate God a gift of money, then you must take it from the 90 percent under your control. A gift beyond what God expects [an offering], demonstrates our love and faith in Him. ${ }^{29}$

In Israel the tabernacle, and later the Temple, were built from the free will offerings"offerings given from a willing heart.(Exodus 36:2-7).

Presenting the principles of money management, Mel Reese, renown stewardship specialist writes:

Successful money management is based upon two eternal principles-First, God's unrestricted ownership and man's restricted stewardship. Constant recognition of this fact will help the Christian spend wisely and economically. He will manage his possessions as the Owner would wish. Second, he will understand the reasons he has been entrusted with material things: to provide sustenance for him and his family; to provide assistance for those in need; to provide support for the cause of God; and as a test to determine his ability to manage eternal things: ${ }^{30}$

\footnotetext{
${ }^{29}$ Smith, 31.
}

${ }^{30}$ Mel Rees, Money and the Christian, (College Place, Washington : Color Press, 1984), 16. 
Not only is financial planning crucial to the success of the Christian steward, but the program of Systematic Benevolence is the sine qua non for formal and consistent giving patterns. Ellen White cites, "God's providence has arranged the entire plan of systematic benevolence for the benefit of man. His providence never stands still. If God's servants follow His opening providence, all will be active workers." 31

What is necessary then to implement this program? The church must develop an annual budget that reflects its needs and those of the community. When that is done, the church must be informed, educated and cultivated to support the budget. The local expenses of the church will be realized by the offerings that are collected from the members. Therefore, it is of importance that after the tithe is returned, a liberal offering is given according to the ability of the giver in relation to the needs of the budget. This must be consistently and systematically given to reflect the needs of the budget. If the program of systematic benevolence were strictly followed, there would be no money problem in the church.

Rees was right when he said:

Money, like sand can sift through the fingers unless carefully controlled; the safeguard is a carefully planned (and followed) budget. A budget does not provide money-it controls spending. Indispensable to this plan is an accurate accounting of all incomes and outgoes. ${ }^{32}$

Rather than having just $21-25 \%$ of habitual givers, there will be $90-100 \%$ giving faithfully and consistently to the cause of Christ and the salvation of humanity.

\footnotetext{
${ }^{31}$ White, Counsels on Stewardship, 180.

${ }^{32}$ Rees, 17.
} 


\section{CONCLUSION}

Stewardship is a partnership with God and man-God as Owner and man as manager.

Stewardship is not just money as some may believe. It is the sum total of life-all that a man is and all that he has. It involves our time, talents, treasurer and temple.

Macchia has crystallized the concept of stewardship most profoundly:

In the healthy church the subject of stewardship is more than financial, with healthy giving flowing out of a lifestyle of stewardship. Life management and stewardship are opposite sides of the same coin-the terms are interchangeable. The central issue is our love for our God with all of our heart, soul, mind and strength and our love for our neighbors as ourselves. It grows into an everdeepening understanding of our own temperament, passion, gift mix, and personal mission. It lives itself out in our focus on serving the needs of people within our sphere of influence. And it all begins with a heart fully devoted to loving the Lord and the people of this world in a manner most befitting his heart. ${ }^{33}$

When the heart is fully committed to God, the pocket books will be consecrated also.

Giving then, the only real numerical measuring rod for stewardship, breaks the power of the dragon of materialism because joyous stewardship puts God first in our life and every check book becomes a theological document. It tells where your treasure is -and thus where your heart is. God is not after our check or pocket books. He is after us-our hearts.

Why then is the church so lacking of the needed resources to advance its cause? It's because she has not been fully surrendered to God. However, surrender must be realized within a context. If the people of God will be faithful stewards, they must be educated in the principles of stewardship. An educated person is in a better position to respond to a call. For surrender is

\footnotetext{
${ }^{33}$ Macchia, 199
} 
not just a matter of the heart but a matter of the head. This education must include but not limited to Stewardship education workshops and financial planning seminars.

It was Henry Edward Felder who once wrote, " Financial planning, rather than indicating a lack of faith, is a way to bring greater harmony and order into activity that is vital to the life of every Christian's prudent management of God's resources. It puts Christ at the center of all activities and seeks His presence in all goals and courses of action.."34

When the world understand true stewardship, there will be a revival and a reformation such as has not been seen before. God will be seen as the supreme Owner and man will understand that he is just a manager. With that concept prevalent in the human mind, teeming millions will ultimately turn to the true God and experience full surrender. This is the ultimate goal of Christian Stewardship.

${ }^{34}$ Henry E. Felder, Making Ends Meet (Hagerstown, Maryland : Review and Herald Publishing Association, 1994), 14. 


\begin{abstract}
APPENDIX B
INSTRUMENTS AND EVALUATION

INSTRUMENTS ANDEVALUATION

\section{APPENDIX B}

ALUATION
\end{abstract}




\section{CHURCH LEADERS-IN-TRAINING PRE-COURSE SURVEY}

Instructions: Using 1 as least in importance and rank and 5 as highest in importance and rank, circle the number to the right of each question which reflects your thinking.

Circle or check the box representing the age group you are in: $\square(10-15), \square(16-22), \square(23-35)$, $\square(36-40), \square(41$ and above)

1. How important do you think a course for training youth to be church leaders is?

2. How important do you think it is to be able to know and explain the twenty-seven fundamental beliefs of the Seventh-day Adventist Church?

3. Do you think that the Church Board plays a vital role in the management and guidance of the church?

4. How important do you think it is to know about the history and development of the Seventh-day Adventist Church?

5. How important in your opinion are church business (members) meetings?

6. How important it is to be and how knowledgeable are you in the area of church leadership and management?

7. How well do you understanding the subject of parliamentary procedures in relation to the conduct of meetings?

8. How do you feel about the prospects of learning the skills of sermon preparation and delivery?

9. How familiar are you with Church Manual?

10. How well do you understand the Importance of the Gift of Prophecy as manifested in the life and ministry of Ellen G. White?

11. Do you have the skills necessary to give personal Bible Studies and lead a soul to make a decision for baptism? 
12. How well do you understand the NEWSTART lifestyle program of the Seventh-day Adventist Health Message? 12345

13. To what degree can you plan and execute the services and meetings of the church?

14. How well do you understand the computer and its functions to include programs and the

12345 use of the internet?

15. How well do you understand the history, development and growth of regional conferences and the need and reason for their existence?

16. How much do you think church leaders should know about Youth Ministries? 


\section{CHURCH LEADERS-IN-TRAINING POST-COURSE SURVEY}

Instructions: Using the \# 1 for Strongly Agree, \# 2 for Agree, \# 3 for Undecided, \# 4 for Disagree and \# 5 for Strongly disagree, circle the number to the right of each statement which reflects your thinking.

Circle or check the box representing the age group you are in: $\square(10-15), \square(16-22), \square(23-35)$, (36-40), $\square(40$ and above)

1. I believe that the church leaders-in-training course for youth is a must

2. I am satisfied with my knowledge of the twenty-seven fundamental beliefs of the Seventh-day Adventist Church.

3. I would love to serve on the Church Board because of my understanding of how it works.

4. I believe I can share with confidence the history and development of the Seventh-day Adventist Church.

5. I have a deeper appreciation for and a better understanding of church business meetings.

6. I have a greater comfort level in assuming a task of leadership in the church.

7. My skills in parliamentary procedures have been greatly sharpened.

8. I feel very comfortable in preparing and delivering sermons.

9. I view the importance of my Church Manual from a different perspective than I had before.

10. I have a greater appreciation for the ministry and life of Ellen G. White. 
11. I am more comfortable to give personal Bible Studies with a view of leading a soul to a decision for baptism.

12. I have a deep appreciation for the legacy of the Health Message given to the Seventh-day Adventist Church.

13. I can plan and help others plan for and execute the various services of the church.

14. I am comfortable with my understanding of the computer and the contribution it is making to a better management of my daily chores.

15. I have a greater appreciation for the history and development of Regional Conferences.

16. I believe that to be a balanced church leader, one should understand all the nuances of Youth Ministries at all levels. 
APPENDIX C

CELEBRATION OF SUCCESS 


\section{WECCOME $\tau 0$}

\section{A SERVICE CELEBRATING SULCESS}

Church Leaders-in-Training Empowerment Program

Brooklyn Temple Seventh-day Adventist Church

Sunday, July 7, 2002, 6:30 PM

Processional

Opening Hymn

Now thank we all our God

Elder L. Robinson

Opening Prayer

Bro. Anthony Springer

Welcome

Sis. Erma Walker

Special Music

Sis. Wayne Cleghorne

Testimony of Participants

Open

Special Music

Sis. Wayne Cleghorne

Pastoral Reflection

Pastor Brian L. Carter

Meditation

Sis. Wayne Cleghorne

Message

Pastor Newton U. Cleghorne

Recognition and Awards

Pastors Carter \& Cleghorne

Closing Song

To God Be the Glory

Theresa Wauchope

Benediction

Isha Mentor

Recessional

\section{Reception in the Fellowship Hall}

Master of CeremoniesPastor B. L. Carter

Remarks

Prayer

Special Music

$$
\text { Elder F. G. Harry }
$$

Sis. Wayne Cleghorne

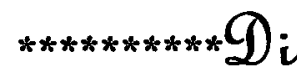

inner $* * * * * * * * * *$

Moments to Remember

Closing Thoughts------------------------Pastor N. U. Cleghorne

Closing Prayer -Sis. Joan Cameron 


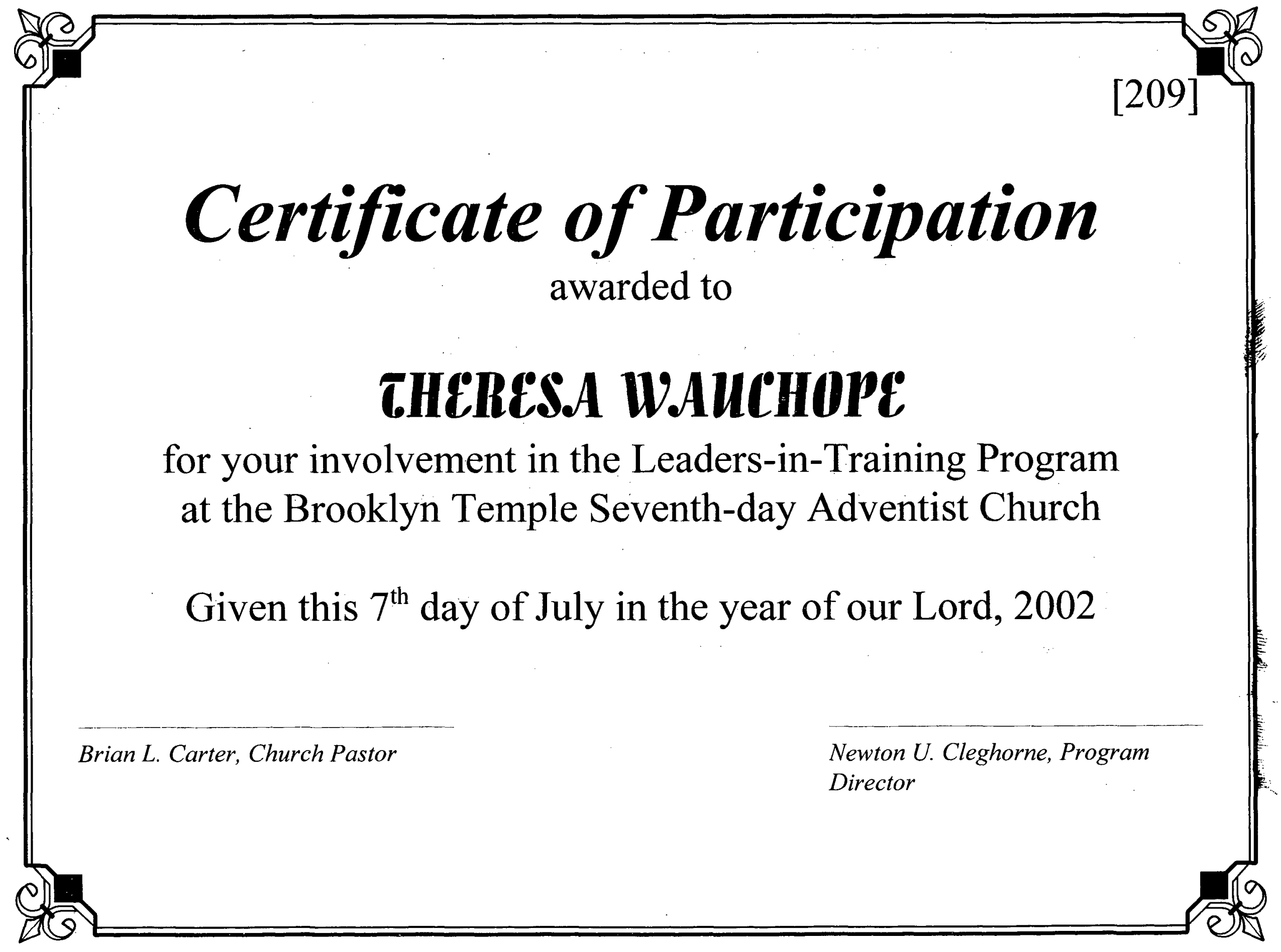




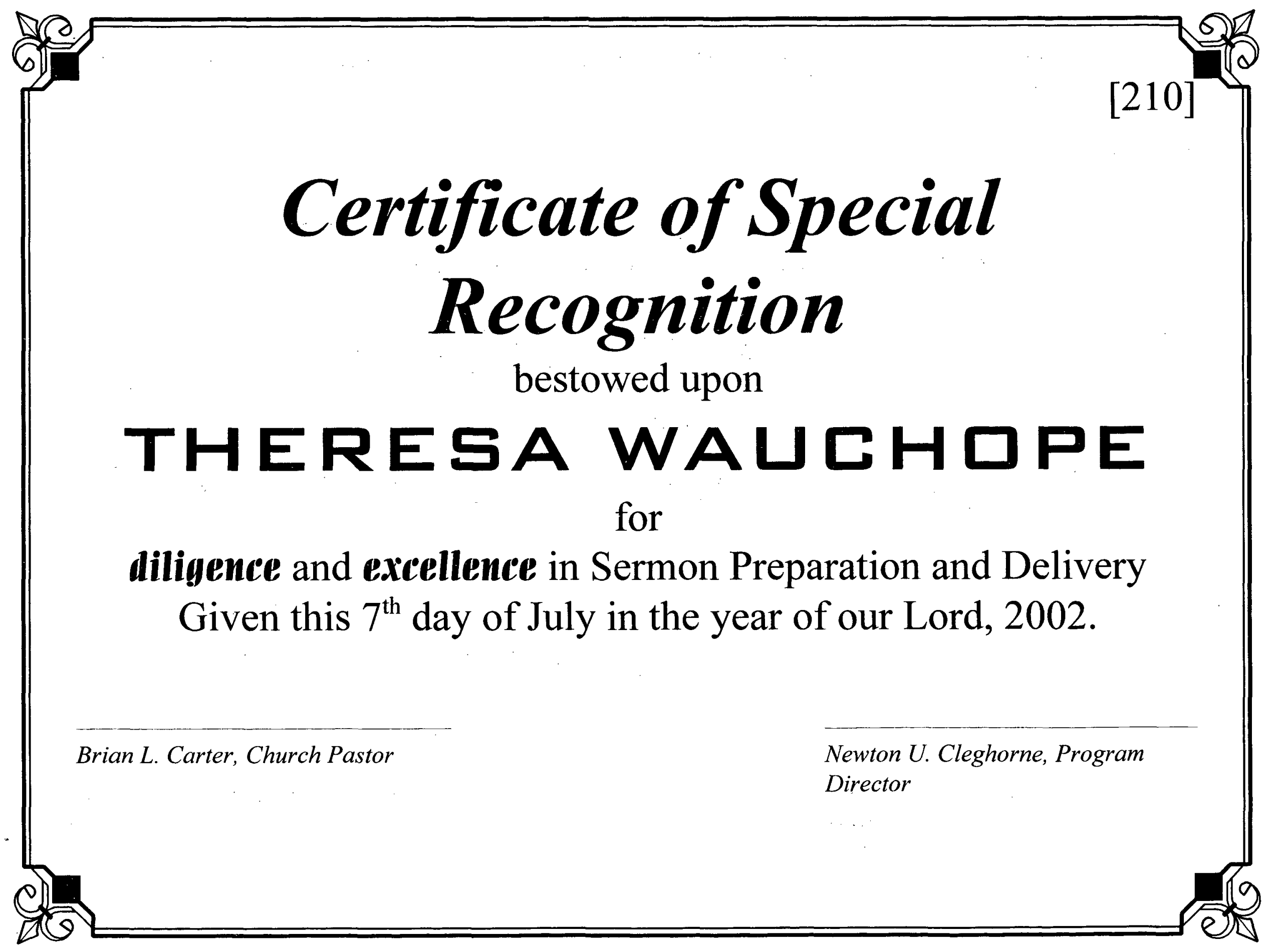


BIBLIOGRAPHY 


\section{BIBLIOGRAPHY}

Adams, Roy. "Perhaps It's Beginning to Rain.” Adventist Review, December 1995, 5.

Allen, Malcolm J. Divine Guidance or Worldly Pressure? Silver Spring, MD: General Conference of Seventh-day Adventists, 1995.

Allen, Patrick, Balvin Braham, and Althea McMillan. "Mentoring Inspires Success." Youth Ministry Accent 1 (2003): 30-33:

An Expository Dictionary of Biblical Words. Edited by W.E. Vine, Merril F. Unger, and William White. Nashville: Thomas Nelson, 1985.

Athanasius. "On the Incarnation of the Word.” In Christology of the Latter Fathers, ed. Edward R. Hardy. Philadelphia: Fortress, 1949.

Beadoin, Tom. Virtual Faith: The Irreverent Spiritual Quest of Generation X. San Fransisco: Jossey-Bass Publishers, 1998.

Benson, Warren S, and Mark H. Senter III, eds. The Complete Book of Youth Ministry. Chicago, IL: Moody Press, 1987.

Blake, Chris. "Adventist Youth: Overentertained and Unchallenged? Adventist Review, July 1993, 10-12.

Borgman, Dean. "Youth Culture, and the Media: Contemporary Youth Ministry." Transformation 11, no. 2 (1944) : 13-15.

Carter, Brian L. "An Appreciation Speech.” The Brooklyn Temple of Seventh-day Adventists, Brooklyn, NY, July 7, 2002.

Celek, Tim, and Dieter Zander. Inside the Soul of a New Generation. Grand Rapids, MI: Zondervan, 1996.

Codrington, Graeme. "12 Sentences That Define Generation Y." August 1999; available from http://www.youth.co.za/resource/geny12.htm; Internet; accessed August 2002. 
Cooper, Emma Howell. The Great Advent Movement. Washington, DC: Review and Herald Publishing Association, 1968.

Dean, Kenda Creasy, Chap Clark, and Dave Rahn, eds. Starting Right. Grand Rapids, MI: Zondervan Publishing House, 1993.

Dudley, Roger L. Why Teenagers leave the Church. Hagerstown, MD: Review and Herald Publishing Association, 2000.

Dudley, Roger, and V. Bailey Gillespie. Valuegenesis: Faith in the Balance. Riverside, CA: La.Sierra Press, 1992.

Erickson, Eric H. Childhood and Society. New York: Norton, 1959.

Englkemier, Joe, ed. Breakthrough with God's Church: Moving Out. Mountain View, CA: Pacific Press Publishing Association, 1980.

Fields, Doug. Purpose-Driven Youth Ministry. Grand Rapids, MI: Zondervan Publishing House, 1998.

Gane, A. Barry. Building Youth Ministry: A Foundational Guide. Riverside, CA: La Sierra University Press, 1997. " "Youth Leadership in the Local Church." D.Min. dissertation, Fuller Theological Seminary, 1993.

Garcio-Marenko, Alfred, ed. Youth Ministry Handbook. Silver Spring, MD: Youth Department of the General Conference of Seventh-day Adventists, 2000.

General Conference of Seventh-day Adventists. General Conference Bulletin, January 29, $30,1893$.

. Pastor's \& Elder's Handbook for Youth Ministry. Silver Spring, MD: General Conference of Seventh-day Adventists, 2002.

Grentz, Stanley. A Primer on Postmodernism. Grand Rapids, MI: Eerdmans, 1996.

Hicks, Rick, and Kathy Hicks. Boomers, Xers and Other Strangers. Wheaton, IL: Tyndale House Publishers, 1999.

Holmes, R. Leslie. "Be Sure to Leave the Light On!” Ministry, November 1998, 5-8. 
Interpreter's Dictionary of the Bible. Edited by George A. Buttrick. New York: Abingdon, 1962.

"I Timothy." The Seventh-day Adventist Bible Commentary. Vol. 6. Edited by Francis D. Nichol. Hagerstown, MD: Review and Herald Publishing Association, 1980.

Jones, Tony. Postmodern Youth Ministry. Grand Rapids, MI: Zondervan Publishing House, 2001.

Kessler, Jay. "Determining Your Theology of Youth Ministry." In Youth Leader's Source Book, ed. Gary Dausey. Grand Rapids, MI: Zondervan, 1983.

Kettler, Christian D., and Todd H. Speidell. Incarnational Ministry. Colorado Springs, CO: Helmers and Howard, 1990.

Kouzes, James M., and Barry C. Postner. The Leadership Challenge. San Fransisco, CA: Jossey-Bass Publishers, 1995.

Krum, Nathaniel. The MV Story. Washington, DC: Review and Herald Publishing Association, 1963.

Maxwell, C. Mervin. Tell It to the World. Boise, ID: Pacific Press Publishing Association, 1977.

McCarthy, Bernice. "Using the 4MAT System to Bring Learning Styles to Schools." Educational Leadership (1990): 31-37.

McMillan, Althea L. Introduction to "Mentoring Inspires Success." Youth Ministry Accent, 1 (2003) : 30-33.

North American Division. A Shared Vision for God's People. San Diego, CA: NK, 191.

North American Division Pathfinder Ministries. Pathfinder Leadership Awards Manual. Silver Spring, MD: NAD Office of Pathfinder Ministries, 1995.

North, James J., Jr. Interview by author, Andrews University, Berrien Springs, MI, 9 August 2002.

Ortiz, Luis Fernando. "Towards a Theology of Youth Ministry and Its Praxis in the Local Church.” D.Min. diss., Andrews University, 1977. 
Richards, Lawrence O. Youth Ministry: Its Renewal in the Local Church. Grand Rapids, MI: Zondervan Publishing House, 1979.

Robbins, Duffy. Youth Ministry: Nuts and Bolts. Grand Rapids, MI: Zondervan Publishing House, 1990.

Savage, Robert C. Pocket Quips. Wheaton, IL: Tyndale House Publishers, 1984.

Schwarz, R.W. Light Bearers to the Remnant. Boise, D: Pacific Press Publishing Association, 1979.

Search Institute. Ways to Show Teenagers You Care. Minneapolis, MN: Search Press, 1966.

Senter, Mark H., III, et al., eds. Four Views of Youth Ministry and the Church. Grand Rapids, MI: Zondervan Publishing House, 2001.

St. Clair, Barry, and Tony Martin, eds. "Equipping Teenagaers to Do Ministry: Investing in the Spiritual Leaders of the Future." In Intensive Caring: Practical Ways to Mentor Youth. Loveland, CO: Group Publishing, 1998.

Stephens, Doug. Called to Care. Grand Rapids, MI: Zondervan Publishing House, 1985.

Swanson, Gary. Sit Down 'Till You Are Thirty-five. Riverside, CA: La Sierra University Press, 1994.

. "The Challenge of Postmodernism: Youth Ministry in a World with Zero Gravity." Youth Ministry Accent 3 (2002): 20-24.

Ward, Peter. God at the Mall. Peabody, MA: Hendrickson Publishers, 1999.

Webster's Dictionary. New York, NY: Random House Publishers, 1991.

White, Ellen G. Acts of the Apostles. Boise, ID: Pacific Publishing Association, 1911. . Christian Education. Battle Creek, MI: International Tract Society, 1893. . Counsels to Parents Teachers and Students. Hagerstown, MD: Review and Herald Publishing Association, 1913.

. Education. Boise, ID: Pacific Press Publishing Association, 1903. 
. A Faith to Live By. Boise, ID: Pacific Press Publishing Association, 1989.

. Gospel Workers. Mountain View, CA: Pacific Press Publishing Association, 1892.

. Life Sketches. Mountain View, CA: Pacific Press Publishing Association, 1915.

. Messages to Young People. Hagerstown, MD: Review and Herald Publishing Association, 1958.

. Ministry of Healing. Boise, ID: Pacific Press Publishing Association, 1942.

. Testimonies for the Church. 9 vols. Mountain View, CA: Pacific Press

Publishing Association, 1948.

Woods, Earl. Training a Tiger. New York, NY: Harper Collins Publishers, 1997.

Young, Robert. Analytical Concordance to the Bible. Grand Rapids, MI: Wm. B. Eerdmans Publishing Company, 1985.

Zoba, Wendy Murray. Generation $2 K$ : What Parent \& Others Need to Know about the Millennials. Downers Grove, IL: InterVarsity Press, 1999. 


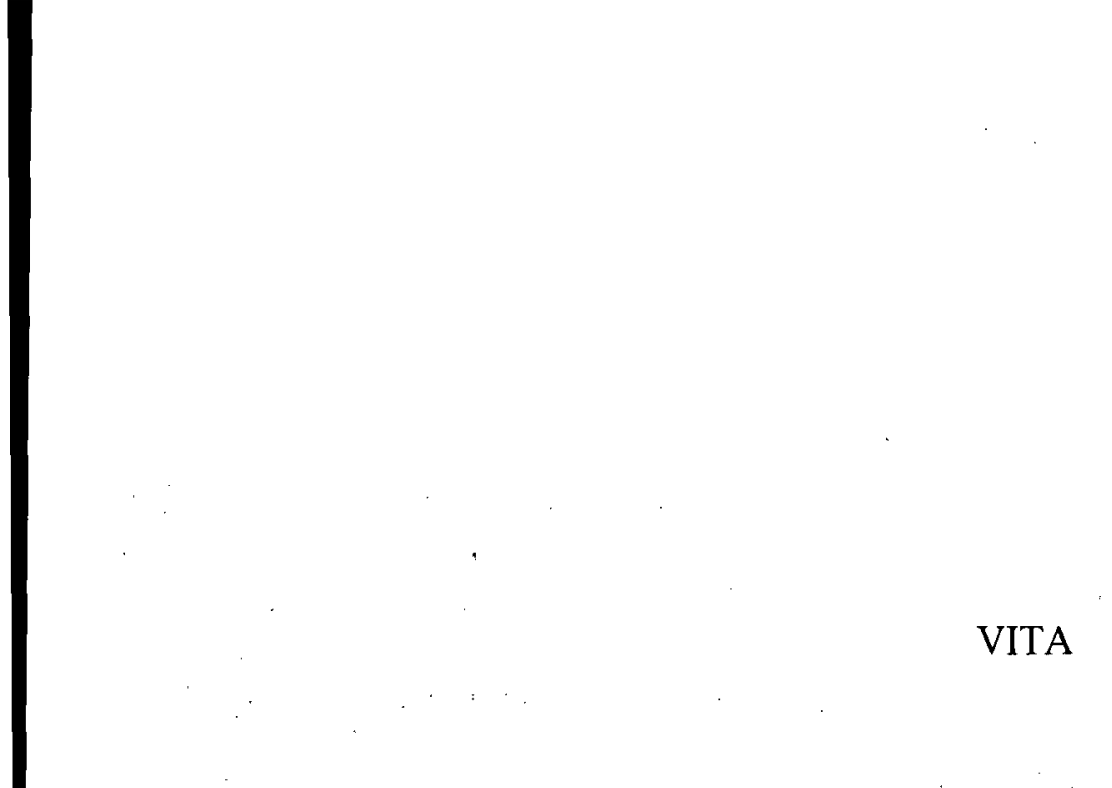

\section{VITA \\ wa \\ VITA}

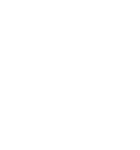

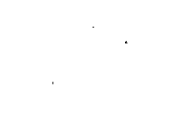

.

\section{(2)}

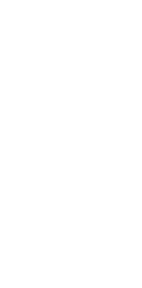




\section{VITA}

Name: Newton Upanton Cleghorne

Place of Birth: Kettering District, Duncans, Trelawny, Jamaica West Indies

Undergraduate and Graduate Schools Attended:

West Indies College (now Northern Caribbean University), Mandeville, Jamaica West Indies Andrews University, Berring Springs, Michigan, U.S.A

Fordham University, Bronx, NY, USA

Pace University, White Plains, NY, U.S.A.

Degrees Awarded:

B.A., Theology, West Indies College, 1979

M.A., Andrews University, 1989

Professional Experience:

1972-'73 Elementary School Teacher G.3 \& 4 Refuge All Age, Refuge, Trelawny, Jamaica 1973-75 Academy Teacher G 9-11, Harrison Memorial High, Montego Bay, Jamaica 1979-`85 District Pastor-Evangelist, West Jamaica Conference of S.D.A. Montego Bay, Jamaica

1988-89 Religion and Mathematics Teacher, Greater NY Academy

1989-‘95 Senior Pastor Sharon SDA Church Northeastern Conference, Jamaica, New York

1995-96 Senior Pastor City Tabernacle, Harlem, NY

1996-Present Youth Ministries Director Northeastern Conference of S.D.A, Jamaica, New York

Marital Status: Married to the former Wayne Ireland, Science Teacher, Nurse and Recording Art. 1980-the present

Philosophy: Young people are God's special instruments to finish His work. Let us do everything in our power to empower them through training, mentoring, positioning and Liberation, so the work will get done and we will be home with Jesus. 